\title{
EDUCAÇÃO E TRABALHO: CAMINHOS DA INCLUSÃO NA PERSPECTIVA DA PESSOA COM DEFICIÊNCIA
}

Dissertação apresentada à Faculdade de Educação da Universidade de São Paulo para obtenção do título de Mestre em Educação.

Área de Concentração: Educação Especial

Orientador(a): Profa. Dra. Maria Luisa Sprovieri Ribeiro 
Autorizo a reprodução e divulgação total ou parcial deste trabalho, por qualquer meio convencional ou eletrônico, para fins de estudo e pesquisa, desde que citada a fonte.

Catalogação na Publicação

Serviço de Biblioteca e Documentação

Faculdade de Educação da Universidade de São Paulo

371.9

Shimono, Sumiko Oki

S556e

Educação e trabalho : caminhos da inclusão na perspectiva da pessoa com deficiência / Sumiko Oki Shimono ; orientação Maria Luisa Sprovieri Ribeiro. São Paulo : s.n., 2008. $118 \mathrm{p}$.

Dissertação (Mestrado - Programa de Pós-Graduação em Educação.Área de Concentração : Educação Especial) - Faculdade de Educação da Universidade de São Paulo.

1. Educação inclusiva 2. Deficientes - Educação 3. Inclusão social 4. Mercado de trabalho 5.Relações familiares I. Ribeiro, Moraes, Luis Sprovieri, orient. 
FOLHA DE APROVAÇÃO

\title{
Sumiko Oki Shimono
}

Educação e Trabalho: Caminhos da inclusão na perspectiva da pessoa com deficiência

Dissertação apresentada à Faculdade de Educação da Universidade de São Paulo para obtenção do título de Mestre em Educação.

Área de Concentração: Educação Especial Orientador(a): Profa. Dra. Maria Luisa Sprovieri Ribeiro

Aprovado(a) em:

\author{
Banca Examinadora
}

Prof. Dr.

Instituição Assinatura:

Prof. Dr.

Instituição Assinatura:

Prof. Dr.

Instituição Assinatura: 
A todos aqueles que acreditam e lutam pela construção de uma sociedade mais justa e solidária. 


\section{AGRADECIMENTOS}

Agradeço, primeiramente, ao carinho e compreensão da minha família pelo tempo que me afastei do convívio para execução deste trabalho.

À Gelre pela oportunidade de ampliar meu aprendizado profissional e estímulo na busca de novos conhecimentos. Agradeço também o apoio para o desenvolvimento desta pesquisa.

Às queridas colegas de trabalho pelas palavras de incentivo.

À minha orientadora pelas observações pontuais e atenção dedicada nos momentos que precisei.

Especialmente às pessoas entrevistadas, principais atores deste projeto profissional, que deram sentido à realização do presente trabalho.

A todos minha gratidão! 
Todos os homens nascem livres e iguais em dignidade e direitos. São dotados de razão e consciência e devem agir em relação uns aos outros com espírito de fraternidade.

Declaração de Direitos Humanos (art.1) 


\section{RESUMO}

SHIMONO, Sumiko Oki. Educação e Trabalho: caminhos da inclusão na perspectiva da pessoa com deficiência. Dissertação (Mestrado em Educação), Faculdade de Educação, Universidade de São Paulo, São Paulo, 2008.

Este trabalho propõe um estudo sobre as histórias de vida de pessoas com deficiência incluídas no mercado formal de trabalho. Apresenta depoimentos de pessoas bem sucedidas no processo de inclusão e suas trajetórias entre a vida escolar e o trabalho. A implantação de políticas públicas para garantir os direitos de cidadania das pessoas com deficiência, trouxe para o debate a inclusão social. Nos últimos anos a oferta de vagas nas empresas públicas e privadas vem modificando o cenário de exclusão desse grupo social. Discute-se a falta de qualificação profissional de pessoas com deficiência como um dos obstáculos ao seu ingresso no mercado de trabalho. $\mathrm{O}$ acesso à educação representa um dos pilares da inclusão dessas pessoas. Entende-se que o debate acerca da inclusão envolve a participação dos principais protagonistas desse processo. Utilizou-se de narrativas autobiográficas como acesso às experiências vividas pelos sujeitos com o objetivo de levantar aspectos facilitadores e dificultadores na relação com o meio social. Considera-se a história oral como reveladora de elementos individuais e coletivos, entendendo o sujeito dentro de um contexto histórico e cultural. A pesquisa envolveu pessoas com deficiência física, auditiva, visual e intelectual. Os resultados confirmam o acesso à educação como garantia de inserção no mercado formal de trabalho. Destaca a importância do papel desempenhado pela família nesse processo. A trajetória bem sucedida não exclui experiências de discriminação vividas na escola e no trabalho. A autonomia das pessoas com deficiência facilita sua integração no ambiente, conduzindo ao enfrentamento das barreiras do preconceito. A reação contra os estereótipos da deficiência e o respeito às diferenças, favorecem a inclusão social.

Palavras- chave: deficiência, inclusão, escola, família, trabalho, diferença. 


\begin{abstract}
SHIMONO, Sumiko Oki. Education and Work: inclusion paths from the perspective of the disabled. São Paulo, FEUSP, 2008. (master's degree dissertation)

This paper proposes a study about life histories of disabled people included in the formal job market. It presents statements of people that succeeded in the social inclusion process and their paths between school and work. The implementation of public policies to guarantee the disabled's citizenship rights has brought the social inclusion to the debate. In the last years, the job vacancies in public and private companies have been changing the picture of this social group exclusion. However, the lack of professional qualification of people with disabilities has been considered to be one of the obstacles to their entrance to the job market. The access to education represents therefore one of the pillars of these people's inclusion. The debate over the inclusion involves the participation of the main characters in this process. Autobiographical narratives have been used as an access to the disabled's life experiences in order to raise aspects that have made their relation with the social circle easy and difficult. The speaking history has been considered to be a revealing tool of individual and collective elements, including the disabled in the historical and cultural context. The research involved people with physical, hearing, visual and mental disabilities. The results confirm that the access to education is a guarantee of inclusion in the formal job market. This paper also points out the importance of the role played by the family in this process. The successful path does not exclude discrimination experiences gone through at school and at work. The autonomy of people with disabilities makes their social inclusion easier, which leads to their prejudice obstacles overcoming. The reaction against the disability stereotypes and the respect for the differences favor the social inclusion.
\end{abstract}

Key words: disability, inclusion, school, family, work, difference. 


\section{SUMÁRIO}

1 INTRODUÇÃO 10

1.1 APRESENTAÇÃO 10

1.2 OBJETO DE ESTUDO 13

1.3 OBJETIVOS 14

1.4 JUSTIFICATIVA 14

1.5 METODOLOGIA 17

2 QUADRO TEÓRICO 18

2.1 PRECONCEITO E EXCLUSÃO SOCIAL 18

2.2 A RELAÇÃO ENTRE SOCIEDADE E DEFICIÊNCIA: UMA HISTÓRIA MARCADA PELA EXCLUSÃO 21

2.3 EDUCAÇÃO E TRABALHO: A LUTA PELOS DIREITOS DA PESSOA COM DEFICIÊNCIA 23

2.4 DO ATENDIMENTO INSTITUCIONAL À ESCOLA INCLUSIVA 27

2.5 TRABALHO E PROTEÇÃO LEGAL: A POLÍTICA DE COTAS NO BRASIL 31

2.6 QUALIFICAÇÃO PROFISSIONAL: COMPETÊNCIAS E EMPREGABILIDADE DA PESSOA COM DEFICIÊNCIA 36

3 A PESQUISA

3.1 RESULTADOS $\quad 42$

3.1.1 Perfil da amostra 42

3.2 ANÁLISE DOS RESULTADOS

3.2.1 Vida escolar 50

$\begin{array}{ll}\text { 3.2.2 O lugar da família } & 60\end{array}$

3.2.3 Inclusão no trabalho 63

3.2.4 O cotidiano: marcas que ficaram

3.2.5 Reflexões sobre o movimento de inclusão social das pessoas com deficiência 88

4 DISCUSSÃO DOS RESULTADOS 95

4.1 DIREITO À EDUCAÇÃO 95

4.2 DIREITO AO TRABAHO 101

4.3 DIREITO DE SER DIFERENTE 105

5 CONSIDERAÇÕES FINAIS

REFERÊNCIAS

$\begin{array}{ll}\text { ANEXOS } & 117\end{array}$ 


\section{INTRODUÇÃO}

\subsection{APRESENTAÇÃO}

A inclusão é um tema que vem conquistando a cada dia maior espaço no cotidiano da sociedade brasileira. Após uma longa história de exclusão, pessoas com deficiência organizaram-se na luta pelo direito de cidadania, reivindicando seu lugar na sociedade e garantias de acesso a todos os seus bens e serviços. A discussão do direito à educação, ao trabalho, ao lazer envolve educadores, empresários, governantes e principalmente as pessoas com deficiência e suas famílias.

Nunca se ouviu e se falou tanto acerca da deficiência. Escolas não podem recusar a matrícula de alunos por sua condição da deficiência, empresas cumprem cotas de vagas reservadas para profissionais com deficiência atendendo à legislação, em meio a denúncias de tratamento discriminado que ainda se fazem presentes.

A área da Educação defronta-se com o desafio de oferecer um ensino de qualidade para todos os alunos inclusive aos que possuem deficiências ou outras necessidades educativas especiais, inseridos no sistema regular de ensino e colocar em prática o princípio da "Educação para Todos". Proclamado pela ONU, em 1990, na Conferência Mundial realizada em Jontien na Tailândia, e reafirmado em 1994, na Espanha, pela Declaração de Salamanca, tal princípio garante o direito de todas as crianças freqüentarem a escola com outras de mesma faixa etária, independentemente de possuir algum tipo de limitação física, sensorial ou intelectual.

Esses movimentos mundiais em prol da democratização do ensino alavancam o processo de inclusão social das pessoas com deficiência, iniciado nos anos $80 \mathrm{em}$ diversos países. No Brasil o MEC - Ministério da Educação e Cultura, define, em 1993, a Política Nacional de Educação Especial e, em 1996 a Lei de Diretrizes e Bases da Educação dedica um capítulo para a Educação Especial.

O movimento de inclusão escolar vem ainda acompanhado de dúvidas e questionamento exigindo não somente apoio e orientação de especialistas, mas principalmente uma reflexão do lugar da escola no desenvolvimento de relações sociais pautadas no respeito às diferenças. 
Observamos mudança significativa nas instituições especializadas que até então assumiram o atendimento das pessoas com deficiência, assistindo à ruptura do modelo segregacionista criando projetos de inclusão em parceria com a comunidade, escolas públicas, particulares e empresas.

O hiato gerado pelas políticas governamentais, que deixaram a educação especial por muitos anos sob a responsabilidade da iniciativa privada, finalmente é preenchido pela esforço conjunto da sociedade. O cenário atual revela a crescente superação de velhos modelos alimentados pelo estigma do diferente, enfrentado pelas pessoas com deficiência, que historicamente mantiveram-se à margem da sociedade.

$\mathrm{Na}$ área do direito ao trabalho, a legislação brasileira adotou uma política de cotas implementada pela lei $n^{o} 8213$ / 91 que, após o início de sua fiscalização no ano 2000, modificou intensivamente o processo de inserção das pessoas com deficiência no mundo do trabalho.

Após algumas décadas, o trabalho das instituições especializadas, somado ao esforço das famílias e, principalmente, ao movimento organizado das pessoas com deficiência, vem conscientizando a sociedade quanto ao reconhecimento do potencial dessas pessoas, percebendo-as como cidadãos produtivos.

Como profissional da educação especial por muitos anos, minha experiência voltouse ao atendimento em instituições especializadas, atuando em programas de diagnóstico e intervenção educativa com crianças e adolescentes portadores de deficiência intelectual.

Embora ciente do modelo de segregação, que por muito tempo predominou nas instituições, não acreditava, desde o meu início de trabalho nas instituições, na prática paternalista e assistencial reforçadora da dependência das pessoas com deficiência. Sempre considerei que o objetivo final do processo educacional é garantir o maior grau possível de autonomia e independência pessoal e o desenvolvimento das potencialidades laborais da pessoa com deficiência, o que lhe irá possibilitar o exercício de sua cidadania e autorealização como pessoa. Procurei manter uma postura crítica, respeitando os direitos de escolha da pessoa com deficiência, sua capacidade de decisão e condições de integração na sociedade. Atuei em programas de preparação profissional e inclusão no mercado de trabalho, baseados no protagonismo da pessoa com deficiência, princípio que sintetiza a relação de respeito e reconhecimento da pessoa como sujeito de direitos. 
Atualmente, desenvolvendo programas de inclusão de profissionais com deficiência nas empresas, observo o preconceito, discriminação, falta de credibilidade nas competências laborais das pessoas com deficiência, constrangimento no relacionamento gerado pela falta de convívio, condições precárias de acessibilidade e ausência de medidas de adaptação nos locais de trabalho.

Todos esses fatores somam-se a outro desafio a ser superado, que é a falta de qualificação profissional das pessoas com deficiência. O baixo nível de escolarização representa outra barreira para sua inserção no mercado de trabalho e integração social e econômica. Em minha experiência observei conquistas diferentes conforme o tipo e severidade da deficiência e que o fator custo do investimento, para tornar acessíveis os postos de trabalho, vem gerando seletividade para o ingresso dessas pessoas no mercado, revelando outras formas de discriminação.

Enquanto alguns enfrentavam tantas dificuldades, outros relatavam trajetórias bem sucedidas quanto ao processo de socialização, escolarização e qualificação profissional de pessoas com deficiência que conquistaram seu espaço na sociedade. Esta vivência gerou indagações, questionamentos sobre os diferentes caminhos percorridos pelas pessoas com deficiência até serem inseridas no mundo do trabalho. Tais narrativas podem acrescentar dados significativos e instigantes para a compreensão do processo de inclusão social.

Mais fortemente percebi a importância da escuta do outro, a necessidade de uma discussão sob a ótica daquele que protagoniza o movimento da inclusão, perspectiva fundamental, se desejarmos rever nossos modelos de intervenção educacional na construção de uma sociedade inclusiva.

Assim pretendi nesse trabalho evitar uma perspectiva unilateral para chegar à compreensão da inclusão social e refletir sobre as condições de acolhimento e integração da pessoa com deficiência na sociedade, partindo da discussão do papel da comunidade, representada pela escola e pela empresa, para reforçar o sentimento de inclusão.

O tema deficiência atinge direta ou indiretamente a sociedade e o movimento em prol da inclusão envolve o compromisso de todos. Adentramos o século XXI com expectativas de profundas mudanças na relação da sociedade com as pessoas com deficiência. A luta organizada desse grupo social, pressionou a implementação de políticas governamentais. São estabelecidas diretrizes quanto à acessibilidade, a partir da Convenção de Guatemala, em 2001, que discute a eliminação de toda e qualquer forma de discriminação contra as pessoas portadoras de deficiência. No Brasil em 02 de dezembro de 2004, o Decreto $\mathrm{n}^{\mathrm{o}} 5296$ 
regulamenta a lei $\mathrm{n}^{\mathrm{o}} 10.048$, de 08 de novembro de 2000 , e a lei $\mathrm{n}^{\mathrm{o}} 10.098$, de 19 de dezembro de 2002, que tratam da prioridade de atendimento às pessoas com deficiência ou com mobilidade reduzida e do estabelecimento de normas e critérios para a promoção da acessibilidade.

Comentando sobre o processo da inclusão, Mantoan (1997) cita:

Segundo Skirt et al. (1996), mais que um novo modelo de serviço aos alunos especiais, a inclusão corresponde ao novo contexto sócio-cultural que emerge no início do século 21. (p.73)

O cenário atual apresenta fortes indícios de mudanças, demonstrando que a inclusão de pessoas com deficiência é um movimento irreversível, porém, necessita de uma construção coletiva, para contribuir como fator determinante na consolidação das relações democráticas de uma sociedade para todos.

\subsection{OBJETO DE ESTUDO}

Assim este trabalho teve como objeto de estudo o histórico de vida de pessoas adultas com deficiência, que se encontram incluídas no mercado formal de trabalho focalizando nas narrativas de vida pessoal, escolar e profissional, os caminhos percorridos e as experiências vividas que as conduziram a um processo de inclusão bem sucedido.

Em virtude do meu interesse em compreender a inclusão social na perspectiva da pessoa com deficiência e investigar o papel da escola e da empresa para reforçar o sentimento de pertencer dessas pessoas, a pesquisa foi centrada em auto biografias.

O estudo incluiu as deficiências física, auditiva, visual e intelectual, buscando identificar elementos comuns ou singulares nas narrativas das pessoas com diferentes limitações.

Pretendeu-se com os relatos autobiográficos, contribuir para a discussão de práticas educacionais inclusivas e possibilitar uma reflexão sobre os aspectos facilitadores e dificultadores do meio social e seu impacto nas pessoas com deficiência.

$\mathrm{Na}$ área da Educação, a pesquisa pretendeu contribuir para o debate sobre a inclusão escolar, especialmente quanto à educação profissional e estimular nos educadores uma revisão dos conceitos e preconceitos que ainda ocorrem quanto ao potencial laboral das pessoas com deficiência. 
Na área do Trabalho, o objetivo foi ampliar a discussão sobre a convivência com a diversidade e as políticas de inserção da pessoa com deficiência nas empresas.

As narrativas autobiográficas podem trazer, reflexões críticas sobre o cotidiano social que produz ou reproduz relações pautadas no preconceito ou no respeito às diferenças entre os seres humanos.

\subsection{OBJETIVOS}

Analisar a trajetória do processo de inclusão social no mercado de trabalho dos sujeitos da pesquisa.

Levantar aspectos facilitadores e dificultadores do processo de inclusão no contexto da escola e da empresa.

Refletir sobre as vivências das relações com a família e a comunidade, e seu impacto no processo de inclusão dos sujeitos pesquisados.

\subsection{JUSTIFICATIVA}

A sociedade discute atualmente políticas de inclusão social, considerando a diversidade como o tema emergente do novo milênio, estimulando práticas que respeitem e integrem as diferenças decorrentes da etnia, credo religioso, gênero, e outras características e atributos individuais.

Em relação à deficiência, a representação da invalidez presente no imaginário social parece lentamente ceder lugar para o reconhecimento e valorização da capacidade da pessoa com deficiência, possibilitando-lhe a participação nas relações de produção de bens e consumo. A pressão de políticas governamentais contribui para a contratação dessa mão de obra, beneficiada no Brasil pelo sistema de cotas.

Nos últimos anos ocorre uma severa físcalização para o cumprimento de cotas previstas em lei, pela ação de órgãos como o Ministério Público do Trabalho - MPT e Ministério do Trabalho e Emprego - MTE.

A intervenção do Estado estimula discussões na sociedade, exigindo uma análise crítica dos conceitos de inclusão e exclusão dentro do modelo capitalista, que enfrenta hoje um sério problema de desemprego e reforça a desigualdade social. 
Nessa perspectiva, algumas questões vão sendo delineadas: qual o lugar das pessoas com deficiência, vistas ainda como seres improdutivos e incapazes? Até que ponto o mundo do trabalho possibilita o exercício de valores, como cooperação, solidariedade, respeito e tolerância às diferenças, quando a competitividade e individualidade predominam sobre o sentimento de coletividade?

Uma possibilidade de análise propõe a compreensão sociológica acerca da relação entre incluídos e excluídos, entre maioria e minoria, entre normal e o anormal. Na concepção de Veiga Neto (2001) ela envolve uma relação entre "dominadores e dominados", assentada em um jogo de poder que tenta naturalizar as diferenças por meio de julgamentos de valor. Para o autor, discutir uma política de inclusão exige compreender o conceito de uma categoria de pessoas excluídas e sua ampliação, entender nossas reações frente à distinção entre incluídos e excluídos, apontando as dificuldades presentes no processo, especialmente aquelas enfrentadas pela educação. Analisando o papel da escola, ele observa a resistência do modelo conservador e a dificuldade para lidar com as inúmeras identidades culturais do todo social. $\mathrm{O}$ autor afirma:

A escola moderna é o lócus em que se dá de forma mais coesa, mais profunda e mais duradoura a conexão entre poder e saber na Modernidade [...]. Isso faz da escola um lugar privilegiado para se observar, por exemplo, tanto as transformações que já aconteceram quanto as que ainda estão acontecendo na lógica social. Faz dela também um lugar atraente para implementar mudanças sobre essa lógica social, que se pretendam necessárias, seja no plano político, cultural ou econômico. Mas isso não significa, absolutamente, que essas sejam operações fáceis. (p.109)

Essa perspectiva estimula uma reflexão sobre a construção social dessas representações sociais e o locus de sua reprodução. A escola, como um espaço de relações sociais, parece ainda reforçar a norma, a ordem, a regularidade do comportamento padrão não considerando as diferenças e singularidades dos indivíduos. Se o "anormal", o "desviante", é concebido como falha ou produto da escola, teria ela condições de desconstruir o que foi construído? Penso que uma postura crítica do educador favoreceria o contexto da inclusão, construindo um ambiente em que alunos com deficiências convivem com os que "normais", estimulando um clima de cooperação e solidariedade. 
Fica uma reflexão sobre o papel da educação:

Apenas a mais ampla das concepções de educação nos pode ajudar a perseguir o objetivo de uma mudança verdadeiramente radical, proporcionando instrumentos de pressão que rompam a lógica mistificadora do capital. (MÉSZÁROS, 2005, p.48)

Além de se constituir em um processo sócio-histórico, a exclusão revela também o sofrimento psicológico dos sujeitos que, submetidos a mecanismos de coação, sofrem a conseqüência na formação de sua identidade, no processo de socialização, nas relações de afetividade com o meio. Atingir o plano da subjetividade, possibilita o acesso ao ser humano em sua totalidade, a sua dimensão social, existencial e afetiva e entender o impacto das práticas de discriminação da sociedade sobre as pessoas.

Se comparamos as barreiras atitudinais do preconceito com as barreiras físicas, estas parecem mais fáceis de ser superadas, pois aquelas dependem de mudanças culturais, do exercício e desenvolvimento de novos valores permeando as relações entre a sociedade e a deficiência.

Em relação à inclusão econômica de pessoas com deficiência, a política de cotas para sua inserção no mercado de trabalho vem atingindo resultados notáveis. Segundo dados publicados em um jornal paulista, a Delegacia Regional de Trabalho - DRT de São Paulo divulgou que as empresas de São Paulo contrataram 75.760 pessoas com deficiência, entre os anos de 2001 à setembro de 2007, e 58,3\% das empresas já cumpriram a meta. (Jornal da Tarde, 21/11/07)

Outros dados entretanto indicam não ser suficiente a legislação de cotas para resolver o problema da exclusão social. Estudos estatísticos realizados por CLEMENTE (2004, p.48) baseados no Censo 2000, do Instituto Brasileiro de Geografia e Estatística -IBGE e dados do DIEESE, verificaram que apenas 3,9\% da população com deficiência em idade de trabalhar seriam empregadas caso a legislação referente a lei de cotas fosse plenamente cumprida. Acrescentando os dados da Relação Anual de Informações Sociais- RAIS, o autor alerta que o número de empresas com mais de 100 empregados vem caindo no Brasil:

Alem de estarem em extinção, as empresas obrigadas por lei a contratarem pessoas portadoras de deficiência são responsáveis por pouco mais da metade dos postos de trabalho gerado no país [...]. Esses números indicam uma necessidade urgente de ações de responsabilidade social do setor para que todas as empresas independente do porte, assumam uma parcela maior 
de PPD em seus quadros, sob pena de manutenção da exclusão entre esse segmento. (p.57)

O autor acrescenta ser necessária uma discussão crítica dos resultados das medidas legais para sua adequação às mudanças do mercado de trabalho.

Outra questão importante é a condição de empregabilidade das pessoas com deficiência. Um enorme contingente de pessoas em idade de trabalho é excluído pela falta de qualificação profissional, resultante da dificuldade de acesso aos bens e serviços coletivos, como saúde, transporte, lazer mas principalmente pela falta de acesso à educação. O espaço da escola assume um papel preponderante no movimento em prol da inclusão, fazendo-se urgente a revisão das práticas educacionais. Garantir a formação profissional da pessoa com deficiência é condição básica para o seu acesso e permanência no mercado de trabalho.

Partindo da análise de narrativas pessoais, a pesquisa abordou a inclusão de pessoas com deficiência, o caminho percorrido até seu ingresso no mercado formal de trabalho, sua formação educacional, as políticas governamentais da área. Entendo que a inclusão reflete o processo histórico de mudanças na sociedade. Envolve aspectos político, econômico e também o ético, determinando novos questionamentos e estudos sobre as diferenças que marcam e enriquecem os seres humanos, com as quais estamos todos aprendendo a conviver.

\subsection{METODOLOGIA}

Ao pretender desenvolver um estudo acerca da inclusão social sob a ótica de seus atores delimitei o fenômeno a ser investigado no campo da subjetividade humana. Questões como o que pensam e sentem, as vivências pessoais desses atores na rede de relações sociais, em um dado momento histórico e cultural, me conduziram à contemplar e utilizar métodos, técnicas e instrumentos de coleta de dados como meios de escuta de narrativas pessoais.

Desenvolvi uma pesquisa bibliográfica e documental, levantando aspectos teóricos sobre preconceito e exclusão social, a relação histórica entre sociedade e deficiência, a luta pelos direitos à educação com referências da legislação e inclusão na escola e no trabalho. Posteriormente realizei uma pesquisa de campo utilizando uma abordagem qualitativa, considerando que a forma naturalista de investigação seria a mais favorável ao objetivo traçado. Tal abordagem possibilitou uma pesquisa do contexto e das variadas dimensões do objeto de estudo. 


\section{QUADRO TEÓRICO}

Do atendimento institucionalizado e segregado à escola e empresa inclusiva, um longo caminho foi percorrido pelas pessoas com deficiência. A evolução do modelo assistencial e paternalista até a postura de inclusão da sociedade nos dias atuais, mostra a luta dessas pessoas pela garantia de seus direitos.

A sociedade discute hoje medidas de acesso e permanência na escola e no trabalho. A política de cotas garante às pessoas com deficiência um percentual de vagas nas empresas públicas e privadas. Entretanto a qualificação profissional, é vista pelos especialistas e empregadores como barreira significativa para a inclusão das pessoas com deficiência no mercado de trabalho o que leva à discussão sobre competências e empregabilidade da pessoa com deficiência.

Além disso acessibilidade ao mundo do trabalho, não significa somente as condições de acesso ao posto e uso de equipamentos de trabalho. Implementar novas tecnologias de apoio representam grande contribuição pragmática, mas não garantem mudanças no ambiente humano. Ao resgatarmos o processo histórico social da inclusão, podemos repensar as barreiras invisíveis construídas pelo preconceito, apontando a necessidade de medidas de sensibilização para aceitação e respeito às pessoas com deficiência.

Assim inicio com uma reflexão sobre preconceito e exclusão social, uma das faces do processo de discriminação da sociedade contra as pessoas com deficiência.

\subsection{PRECONCEITO E EXCLUSÃO SOCIAL}

A relação entre a sociedade e as pessoas com deficiência, marcada pela discriminação e preconceito, sofreu profundas mudanças na sociedade contemporânea, trazendo um cenário aparentemente mais humanizado de convívio social entre os diferentes.

O modelo excludente, baseado em uma postura paternalista e assistencialista, que reforçava a segregação e a dependência das pessoas com deficiência, começa a ser questionado. O movimento de inclusão, iniciado nos anos 80, propõe uma integração plena das pessoas com deficiência, seja na escola, trabalho e na comunidade garantindo a elas o acesso aos serviços, bens e equipamentos sociais. (SASSAKI, 1997) 
Observa-se o início de uma mudança cultural, em que a valorização da diversidade humana passa a representar a possibilidade de uma construção de novas relações entre os membros da sociedade. Entretanto, muito temos ainda a caminhar nessa luta, para garantir os direitos de cidadania conquistados pelas pessoas com deficiência.

Os desafios são de natureza complexa, exigindo revisão crítica dos preconceitos quanto às diferenças, valores éticos e humanos, reconhecimento do direito de todos de pertencer e de ser respeitado em sua diversidade. Por muito tempo esse direito foi negado àqueles que se situam à margem dos padrões da normalidade impostos por uma maioria.

Para Veiga Neto (2001), discutir uma política de inclusão requer a compreensão do conceito de uma categoria de pessoas excluídas e entender nossas reações frente a distinção entre incluídos e excluídos. Apoiado nas contribuições de Foucault (1999) e Balman (1999) refere que a modernidade buscou um novo ordenamento, operado pelo poder: fortaleceu a norma, a regra da conduta, a regularidade, em contraponto com a desordem, a doença, a patologia.

Observa o autor que, além do critério do corpo e seus defeitos, desvios da morfologia ou da conduta, a norma hoje se estende ao plano econômico incluindo na categoria dos excluídos os sem-terra e desempregados, ampliando a relação do poder e o uso da norma como estratégia de dominação. Nessa mesma perspectiva Duschatzky e Skliar (2001) respondem quem são os outros:

\begin{abstract}
A Modernidade inventou e se serviu de uma lógica binária, a partir da qual denominou de diferentes modos o componente negativo da relação cultural: marginal, indigente, louco, deficiente, drogadinho, homossexual, estrangeiro etc. Essas oposições binárias sugerem sempre o privilégio do primeiro termo e o outro, secundário nessa dependência hierárquica, não existe fora do primeiro mas dentro dele, como imagem velada, como sua inversão negativa. (p.123)
\end{abstract}

Estes autores afirmam que tal modo de pensar deixa supor que "[...] a pobreza é do pobre, a violência, do violento... a deficiência do deficiente, a exclusão, do excluído".

Como refere Veiga Neto (2001) frente ao normal e anormal, as reações da sociedade da maioria podem evidenciar uma "prática explícita e radical" de exclusão ou naturalizar essa diferenciação legitimando a norma como certa. Nesse sentido afirma:

Então, o que ainda é preciso fazer é referir como apareceu a díade normal anormal ou, em outras palavras, de onde vem o conceito moderno de normalidade. Isso é aqui de fundamental importância, tendo em vista que 
aquilo que está na pauta das políticas de inclusão é, justamente, saber o que fazer com os anormais. (p.113)

Há de se ter o cuidado na inclusão do outro, pois ao adotar uma postura de aceitação condescendente podemos reproduzir o preconceito. Duschatsky e Skliar (2001) alertam sobre a tolerância às diferenças, provocando um questionamento das nossas práticas: ao invés de respeitar verdadeiramente as diferenças representam um discurso conservador, ou seja, no fundo estamos de fato excluindo.

A tolerância pode traduzir um grau de aceitação que não dá conta do processo de constituição do outro como sujeito político. Se não lida com o conflito da diferença, mantém o discurso da homogeneidade e não a problematiza. A falsa tolerância mascara as desigualdades torna-se ambígua. "A tolerância tem uma grande familiaridade com a indiferença", afirmam os autores. (p.136)

A sociedade ao impor aos seus membros a cultura da homogeneidade, serve-se dos estereótipos como categorias rígidas frente aos objetos assim classificados para "melhor manipulá-los". (CROCHIK, 1995)

Como produto disponibilizado pela cultura o estereótipo iguala os objetos, constituindo-se na concretização do preconceito. Como refere Amaral (1995), o "olhar prédestinado ou pré-formado" impede o verdadeiro contato com o outro e consigo mesmo e assim a própria experiência fica impedida. A autora afirma que aqueles que não correspondem ao "tipo ideal" são os "[...] desviantes, alvos potenciais da discriminação desencadeada pelo preconceito". (p.28)

Segundo Crochík (1995), “o preconceito prepara a ação da exclusão do mais frágil, por aqueles que não podem viver a sua fragilidade, numa cultura que privilegia a força". Em um mundo de contradição o movimento de inclusão enfrenta o acelerado desenvolvimento tecnológico que tornou-se um fim em si mesmo, a serviço do capital em detrimento do homem. Naturalizamos os fenômenos, o indivíduo, apartados de uma visão histórica e crítica, eliminando as dúvidas, facilitando o predomínio da homogeneidade e da necessidade dos estereótipos.

Adorno (1995), afirma que vivemos em uma sociedade em que a adesão a idéias estereotipadas é fortalecida pelos veículos de massa, constituindo-se em uma forma não diferenciada, não reflexiva ou acrítica. A adesão representa um obstáculo à diferenciação e somente a reflexão sobre a experiência possibilitaria a educação emancipatória conduziria os indivíduos a autonomia. 
De acordo com Crochik (1995), há uma tendência à perpetuação da realidade regida pelo capitalismo, em que os interesses humanos são esquecidos. A inclusão representaria conquista e respeito ao humano, pois o preconceito, como forma de excluir o outro leva ao não reconhecimento das diferenças. Argumenta o autor que "ao excluir o outro estamos excluindo algo de nós mesmos".

\subsection{A RELAÇÃO ENTRE SOCIEDADE E DEFICIÊNCIA: UMA HISTÓRIA MARCADA PELA EXCLUSÃO}

Desde o período mais primitivo da história da civilização humana, as relações foram determinadas pelas diversas representações sociais conforme a organização de uma dada sociedade. Frente às pessoas com deficiência, atitudes de total exclusão dos povos antigos foram lentamente sendo substituídas por relações sociais de acolhimento, tolerância e respeito à diversidade, mudanças iniciadas a partir do século XX e difundidas com a chegada do novo milênio.

No estudo desta história Bueno (1993) apresenta uma síntese baseando-se em Kirk e Gallagher (1987) referindo a quatro estágios: era pré-cristã uma época de maus tratos e negligência, era cristã com predomínio da postura de proteção, seguindo-se o período entre os séculos XVIII e XIX quando surgem as instituições de atendimento segregado, e por fim a partir do século XX um movimento de aceitação visando a integração das pessoas com deficiência.

$\mathrm{Na}$ Antiguidade crianças com deformidades eram abandonadas, maltratadas ou exterminadas, observando-se profundas mudanças na sociedade a partir do cristianismo na Idade Média. Surgem as primeiras formas de atendimento e assistência em asilos, mosteiros e hospitais mantidos pela Igreja. Abrigadas e protegidas, pessoas pobres, doentes e deficientes passam a ter a subsistência garantida, ainda que segregadas e marginalizadas da sociedade.

Segundo Pessotti (1984) os valores de caridade poupavam as crianças com deficiência porém, a atitude ambígua de proteção-segregação indicava a rejeição e o isolamento dos indesejáveis. Comenta o autor: 
[...] assim que passam a ser, ao longo da Idade Média, "lês enfants du bom Dieu" (os filhos de Deus), numa expressão que tanto implica a tolerância e a aceitação caritativa quanto encobre a omissão e o desencanto de quem delega à divindade a responsabilidade de prover e manter suas criaturas deficitárias [...]. (p.48)

As formas que as relações entre deficiência e sociedade vão assumindo, retratam as crenças, valores de um certo período da história. Nesse sentido Fonseca (1991) destaca:

Nos séculos XVI e XVII a mitologia, o espiritismo e bruxaria dominaram e afetaram a visão da deficiência, de onde decorreram julgamentos morais, perseguições, encarceramentos, etc. Em suma, meios claramente demonstrativos de valores de ordem social e de controle social. (p.10)

Na opinião de Bueno (1993), o período das instituições de segregação revelam:

[...] o isolamento daqueles que interferiam e atrapalhavam o desenvolvimento da nova forma de organização, baseada na homogeneização e na racionalização. (p.63)

Segundo este autor pode-se caracterizar esses dois séculos como:

[...] um movimento contraditório de participação-exclusão que caracteriza todo o desenvolvimento da sociedade capitalista, que se baseia na homogeneização para a produtividade e que perpassará toda a história da educação especial. (p.63)

Bueno (1993) analisa as diferenças entre o acesso da elite e da massa. As crianças cegas ou surdas oriundas da nobreza e da burguesia em ascenção recebiam os tratamentos, deixando as outras "largadas à própria sorte".

Mudanças significativas na concepção da deficiência vão ocorrer com a organização da sociedade na luta pelos ideais de liberdade.

A Revolução Francesa foi, neste sentido, um novo período em que as atitudes filosóficas e antropológicas se conjugaram numa perspectiva mais humanista da deficiência. (FONSECA, 1991, p.10)

A Renascença foi um período de profundas mudanças no pensamento humano possibilitando a era do conhecimento científico. A representação da deficiência superando o 
enfoque mágico, supersticioso da sociedade primitiva, abandona a explicação teológica da era feudal e passa a ser concebida como determinada por princípios e leis naturais.

Guhur (1994) em sua análise sobre a representação da deficiência mental adota uma perspectiva histórica quanto ao papel social das pessoas com deficiência após a Idade Média. A mudança do homem camponês para a cidade, dispondo de sua força de trabalho, gera uma nova condição: o homem livre. Para a autora essa "pretensa igualdade" decorre leva à desigualdade, pois o homem que, mesmo livre na cidade, não se adequar aos novos modos de produção ou não puder trabalhar nas condições oferecidas, será condenado à ociosidade e ao estigma da incapacidade.

Esse homem que não trabalha, contrariando sua condição natural, passa para a tutela do Estado sendo encaminhado a instituições como asilos e hospitais. Afastado das relações de trabalho e de produção, portanto das relações sociais, não atinge a existência com um sujeito histórico.

$\mathrm{Na}$ atualidade o estigma da incapacidade ainda persegue as pessoas com deficiência. Segundo Goffman (1982) o indivíduo estigmatizado é sinônimo de "banido socialmente", à margem do convívio. Na sociedade atual, egressos do sistema presidiário, alcoólatras, homossexuais, pessoas portadoras de deficiências, representam os grupos minoritários, categorias diferenciadas que ganham visibilidade e são discriminadas por seus atributos, condições ou características que diferem da maioria considerada normal. Diante de membros diferentes, a sociedade reage com mal estar e constrangimento, discriminação e preconceito ou muitas vezes simplesmente os ignoram.

O cenário de exclusão social vai se modificando, na medida em que as políticas públicas passam a desenvolver ações afirmativas, que reduzem as barreiras de discriminação e garantem o bem estar a todos os membros da coletividade. Em paralelo as pessoas com deficiência vão se organizando na luta pelos seus direitos, com movimentos sociais capazes de gerar impacto nas relações sociais e na sociedade. (SASSAKI, 1997)

\subsection{EDUCAÇÃO E TRABALHO: A LUTA PELOS DIREITOS DA PESSOA COM DEFICIÊNCIA}

A Declaração dos Direitos do Homem, resultante da Revolução Francesa, no século XVIII, constitui a base para a Declaração Universal dos Direitos Humanos, aprovada pela Organização da Nações Unidas - ONU em 1966: 
Todo homem tem capacidade para gozar os direitos e as liberdades estabelecidas nesta declaração sem distinção de qualquer espécie, seja de raça, cor, sexo, língua, opinião política ou de outra natureza, origem nacional ou social, riqueza, nascimento, ou qualquer outra condição.(Art. 2, I)

A luta pelos direitos das pessoas com deficiência ganhou intensidade nas últimas décadas, por meio de movimentos mais organizados e apoio de órgãos intergovernamentais. PASTORE (2000) destaca a aprovação da Declaração dos Direitos das Pessoas Deficientes pela Assembléia Geral da ONU, em 1975 que declara:

Às pessoas portadoras de deficiência têm o mesmo direito, inerente a todo e qualquer ser humano, de ser respeitadas, sejam quais forem seus antecedentes, natureza e severidade de sua deficiência. Elas têm os mesmos direitos que os outros indivíduos da mesma idade, fato que implica desfrutar de uma vida descente, tão normal quanto possível.

O movimento dos direitos dessas pessoas ganha visibilidade no ano de 1981, declarado pela ONU como o Ano Internacional das Pessoas Deficientes, sob o lema participação e igualdade plenas.

Na década de 80 a Assembléia Geral das Nações Unidas em 03 de dezembro de 1982 aprova o PAM - Programa de Ação Mundial para a Pessoa Portadora de Deficiência.

A igualdade de oportunidades é o processo mediante o qual o sistema geral da sociedade - o meio físico, cultural, a habitação, o transporte, os serviços sociais e saúde, as oportunidades de educação e trabalho, a vida cultural e social, inclusive as instalações esportivas e de lazer- torna-se acessível a todos. (Art.12, PAM-ONU, 1982, apud PASTORE, 2000)

A Convenção 159, da Organização Internacional do Trabalho - OIT, realizada em Genebra, em 1983, referendada no Brasil pelo Decreto $\mathrm{n}^{\circ} 129$ / 91, recomenda aos países membros medidas para a formação profissional, colocação e emprego de pessoas com deficiência.

Para efeitos desta Convenção, todo País Membro deverá considerar que a finalidade da reabilitação profissional é a de permitir que a pessoa deficiente obtenha e conserve um emprego e progrida no mesmo, e que se promova assim a integração dessa pessoa na sociedade. (Art. 1, item 2, Convenção 159- OIT)

As autoridades competentes deverão adotar medidas para proporcionar e avaliar os serviços de orientação e formação profissional, colocação, emprego e outros semelhantes a fim de que as pessoas deficientes possam obter e conservar emprego e progredir no mesmo; sempre que for possível e 
adequado, serão utilizados os serviços existentes para os trabalhadores em geral com aptidões necessárias. (Art.7, Convenção 159 - OIT)

A organização social das pessoas portadoras de deficiência defende a não discriminação, o respeito, a dignidade, os direitos civis e políticos, os direitos a tratamentos que assegurem o desenvolvimento máximo de suas potencialidades.

No Brasil, o Decreto n ${ }^{\circ} 3298$, de 20 de dezembro de 1999, regulamenta a Lei $\mathrm{n}^{\mathrm{o}} 7853$ / 89, que dispõe sobre a Política Nacional para a Integração da Pessoa com Deficiência, quase 10 anos depois de sua edição consolidando as normas de proteção.

Art. $2^{\circ}$ Cabe aos órgãos e às entidades do Poder Público assegurar à pessoa portadora de deficiência o pleno exercício de seus direitos básicos, inclusive dos direitos à educação, à saúde, ao trabalho, ao desporto, ao turismo, ao lazer, à previdência social, à assistência social, à edificação pública, à habitação, à cultura, ao amparo à infância e à maternidade, e de outros que, decorrentes da Constituição e das leis, propiciem seu bem estar pessoal, social e econômico.

Cria a Coordenadoria Nacional para a Integração da Pessoa com Deficiência CORDE e o Conselho Nacional das Pessoas com Deficiência - CONADE, para implementar uma política conjunta do Estado e sociedade civil em todos os campos: educação, saúde, cultura, lazer, turismo, ajuda técnica, habilitação e reabilitação profissional.

Desde a década de 80 já havia a discussão sobre a inclusão como novo modelo para as ações de atendimento na área da deficiência. A Declaração de Salamanca (1994) documento que reafirma o compromisso com a Educação para Todos, do qual o Brasil é signatário, defende a criação de escolas integradoras, capaz de atender as necessidades especiais referindo que:

As escolas comuns, com essa orientação integradora, representam o meio mais eficaz de combater atitudes discriminatórias, de criar comunidadesacolhedoras, construir uma sociedade integradora e dar educação para todos; além disso, proporcionam uma educação efetiva à maioria das crianças e melhoram a eficiência e, certamente, a relação custobenefício de todo o sistema educativo.

$\mathrm{Na}$ década de 90, começa-se a falar de escola inclusiva, empresa inclusiva, procurando compreender a deficiência como um conceito social e construir o modelo da sociedade inclusiva, que : 
[...] precisa ser baseada no respeito de todos os direitos humanos e liberdades fundamentais, diversidade cultural e religiosa, justiça social e as necessidades especiais de grupos vulneráveis e marginalizados, participação democrática e a vigência do direito. (Nações Unidas, 1995, apud SASSAKI, 1997, p.9)

A deficiência passa a ser entendida de acordo com as condições do meio, que podem gerar maior ou menor desvantagem para as pessoas com deficiência. Nas sociedades mais desenvolvidas procura-se reduzir as limitações das pessoas com deficiência, desenvolvendo novos e avançados métodos de reabilitação e assistência educacional, além do aperfeiçoamento das tecnologias de apoio. Ao mesmo tempo buscam modificar o ambiente melhorando as condições de acessibilidade, estabelecendo normas que garantam a funcionalidade das edificações e vias públicas, removendo os obstáculos, possibilitando acesso aos meios de transporte, logradouros e equipamentos públicos das pessoas com deficiência.

Apoio e ambiente transformam-se nas palavras chave que reduzem as limitações, facilitando o processo de adaptação de pessoas com deficiência, promovendo seu acesso a bens e serviços, melhorando sua qualidade de vida. Essas medidas são compatíveis com “princípios inclusivistas”, como assinala Sassaki (1997):

Inclusão é o processo pelo qual a sociedade se adapta para poder incluir em seus sistemas gerais, pessoas com necessidades especiais e simultaneamente estas se preparam para assumir seus papéis na sociedade. A inclusão social constitui então um processo bilateral no qual as pessoas ainda excluídas e a sociedade buscam equacionar problemas, decidir sobre soluções e efetivar a equiparação de oportunidades para todos. (p.3)

A Convenção da Guatemala - Convenção Interamericana para a Eliminação de Todas as Formas de Discriminação contra as Pessoas Portadoras de Deficiência - realizada pela Organização dos Estados Americanos - OEA, em 1999, promulgada pelo Brasil, em 2001, reforça medidas que reduzam as barreiras físicas e atitudinais enfrentadas ainda pelas pessoas com deficiência.

Na perspectiva da inclusão, pessoas com deficiência passam a exercer a cidadania, organizadas na luta pelos seus direitos, buscando cada vez mais a autonomia, liberdade de escolha e vida independente. 
Os conceitos inclusivistas constituem a base para definir as estratégias dos programas de ação focalizados na autonomia, independência e empowerment, que sintetizam o "estilo de vida independente". O termo empowerment vem sendo habitualmente usado como empoderamento e definido por Sassaki (2003) como:

Empowerment significa o processo pelo qual uma pessoa, ou um grupo de pessoas, usa o seu poder pessoal inerente à sua condição - por exemplo: deficiência, gênero, idade, cor-para fazer escolhas e tomar decisões, assumindo assim o controle de sua vida. (p.38)

O estilo de vida independente é fundamental no processo de inclusão pois com ele as pessoas portadoras de deficiência terão maior participação de qualidade na sociedade, tanto na condição de beneficiários dos bens e serviços que ela oferece, como também na decontribuintes ativos no desenvolvimento social, econômico, cultural e político da nação. (p.53)

Apesar do movimento pela independência pessoal, física e econômica, as pessoas com deficiência ainda são tratadas pela família e sociedade como incapazes de tomar decisões, ter pouco controle sobre suas vidas, seus desejos e as escolhas são assumidos por outros. O lema "Nada sobre nós sem nós" foi certamente uma incisiva mensagem para a sociedade em 2004, por ocasião do Dia Internacional da Deficiência. O direito à voz e participação nas decisões passa a representar os anseios das pessoas com deficiência, que almejam independência e autodeterminação para viver em sociedade.

\subsection{DO ATENDIMENTO INSTITUCIONAL À ESCOLA INCLUSIVA}

Existe uma concordância entre os autores, apontada por Bueno (1993), que a educação da criança surda no século XVI marca o início da educação das pessoas com deficiência. Esse trabalho desenvolvido na Espanha dirigiu-se para a elite da época. Educadores de crianças surdas são também localizados em outros países da Europa a partir do século XVII, sempre como privilégio da aristocracia.

Referindo aos trabalhos do médico Esquirol estabelecendo a diferença entre deficiência e doença mental, na segunda metade do século XIX, Pessoti (1984) afirma que inicia a possibilidade de educar pessoas com deficiência intelectual.

Segundo Bueno (1993), o surgimento das instituições públicas especializadas no século XVIII indica um esforço da sociedade em oferecer uma educação às pessoas com deficência. Até então, restrita à elite, a educação deixava os pobres sem assistência, sobrevivendo pela mendicância. Entretanto afirma o autor que: 
[...] na mediada em que se deslocou da elite para o povo miúdo, cumpriu função segregadora, confinando os mais pobres no interior das instituições, respondendo ao processo de racionalização da sociedade, que passou a exigir, cada vez mais, o afastamento dos desocupados e o seu encaminhamento, de alguma forma, para o processo produtivo. (p.67)

Bueno (1993) faz referência ao atendimento institucionalizado para cegos, citando o Instituto de Trabalhadores Cegos na França do século XVIII, que só atendia cegos que pudessem trabalhar.

[...] em apenas 10 anos se transformou em escola industrial e asilo combinados, expressão que nada mais é que um eufemismo para encobrir a internação dos cegos que, em troca de moradia e alimentação, deveriam corresponder com trabalho obrigatório. (p.69)

A situação das pessoas com deficiência intelectual não diferia e assim

[...] surdos e loucos, cegos e mendigos todos faziam parte do movimento maior de segregação dos divergentes, dos que atrapalhavam o desenvolvimento do capitalismo e que necessitavam ser enquadrados às suas exigências, todos se encaminhando para a internação e para o trabalho forçado, manual e tedioso, parcamente remunerado, quando não em troca de um lugar no "maravilhoso espaço do asilo-escola-oficina". (BUENO, 1993, p.69)

No rastro do espírito filantrópico, as instituições foram se espalhando em sistemas de internato. Nesse atendimento, o interesse mais voltado pela mão de obra restringia a escolarização a patamares inferiores. Com a exigência do desenvolvimento industrial, as instituições foram se voltando ainda mais à preparação para o trabalho. (BUENO, 1993)

Esse panorama revela que as instituições especializadas desempenharam um papel fundamental na história do atendimento de pessoas com deficiência. No Brasil o percurso foi similar. Instituição como o Instituto Benjamim Constant no Rio de Janeiro foi fundada no período imperial. (SILVA, 1987)

Em sua grande maioria originada de movimentos associativos de pais, algumas delas detêm grande experiência no atendimento à deficiência sendo instituições de referência.

Todavia a oferta de recursos especializados pelas escolas públicas ou particulares e instituições de atendimento à deficiência, não atende ao anseio da sociedade para assegurar o direito de todos à educação. As políticas de acesso à educação para pessoas com deficiência vão garanti-lo por meio da escola inclusiva. 
Crianças e jovens com deficiência começam a integrar-se na sociedade graças às oportunidades abertas pelas escolas regulares, processo ainda marcado pelo conflito com o modelo segregado de atendimento educacional. Os educadores começam a rever o modelo excludente e o paradigma da inclusão passa a nortear as políticas públicas.

A resolução CNB/CEB No 2 de 11 de setembro de 2001 que institui as Diretrizes Nacionais para a Educação Especial na Educação Básica em seu Art. $2^{\circ}$ diz:

Os sistemas de ensino devem matricular todos os alunos, cabendo às escolas organizar-se para o atendimento aos educandos com necessidades educacionais especiais, assegurando as condições necessárias para uma educação de qualidade para todos.

O movimento da educação inclusiva gera uma revisão das práticas educacionais pelas instituições que, por muito tempo mantiveram-se no modelo paternalista e assistencialista.

A tarefa é um tanto complexa, como aponta D’Antino (1998), pois é necessário superar o nível do instituído. A clientela institucionalizada ocupa um espaço definido por uma prática protecionista e em seu cotidiano nem sempre há um pensar e fazer críticos. A autora analisa as relações entre os atores institucionais, o envolvimento dos pais e profissionais, as idealizações, as relações de poder e conflito. Em sua opinião, o clima de ambigüidade e contradição nas instituições, desloca o investimento de energia em detrimento do sujeito concreto o aluno.

Observamos uma adaptação das instituições ao novo cenário da inclusão, especialmente nos programas de capacitação para o trabalho. Tradicionalmente o programa de oficinas foi a estratégia utilizada para preparação dos aprendizes para o trabalho. $\mathrm{Na}$ área da deficiência intelectual ainda são comuns as oficinas protegidas e terapêuticas, voltadas a pessoas com maior dificuldade de autonomia. De acordo com o Art. 35 do Decreto n 3298 / 99 assim são definidas as oficinas:

Considera-se oficina protegida de produção a unidade que funciona em relação de dependência com entidade pública ou beneficientede assist $\sim$ encia social, que tem por objetivo desenvolver programa de habilitação profissionalpara adolescente e adulto portador de deficiência, provendo-o com trabalho remunerado, com vista à emancipação econômica e pessoal relativa. ( parágrafo $4^{\circ}$ )

Considera-se oficina protegida terapêutica a unidade que funciona em relação de dependência com entidade pública ou beneficiente de assistência social, que tem por objetivo a integração social por meio de atividades de 
adaptação e capacitação para o trabalho de adolescente e adulto que devido ao seu grau de deficência, transitória ou permanente, não possa desempenhar atividade laboral no mercado competitivo de trabalho ou em oficina protegida de produção. ( parágrafo $5^{\circ}$ )

Como a própria denominação já refere, o ambiente protegido de aprendizagem e produção é condizente para pessoas com deficências mais severas, sendo importante avaliar o potencial laboral dos aprendizes e suas condições de inserção no mercado competitivo de trabalho, a fim de não restringir para todos os casos o programa de capacitação profissional às atividades das oficinas.

Assumindo o desafio da inclusão profissional os programas de capacitação para o trabalho envolvem habilidades de informática, cursos de telemarketing, entre outros, ajustando-se às necessidades e exigências do mercado.

A preocupação com a educação profissional da pessoa com deficiência está presente na Resolução $n^{\circ} 2$ do CNB/CEB, no seu art.17:

Em consonância com os princípios da educação inclusiva, as escolas das redes regulares de educação profissional, públicas e privadas, devem atender alunos que, mediante a promoção das condições de acessibilidade, a capacitação de recursos humanos, a flexibilização e adaptação do currículo e o encaminhamento para o trabalho, contando, para tal, com a colaboração do setor responsável pela educação especial do respectivo sistema de ensino.

O parágrafo $1^{\circ}$ deste artigo trata das parcerias entre centros de formação profissional com as escolas especiais públicas ou privadas para validação dos cursos profissionalizantes realizados por elas.

\section{O Programa de Inclusão de Pessoas Portadoras de Deficiência nas Ações} Educacionais do SENAC (2002) é resultado da sistematização das ações nessa área. A Escola do SENAI de Itu-SP, desde 1996, vem oferecendo cursos de capacitação profissional na perspectiva da educação inclusiva. (Revista Caminhos da Inclusão, 2005)

Considero importante refletir sobre os programas de inclusão profissional, na perspectiva de uma educação formadora de cidadão críticos. Ao oferecer o treinamento focados em habilidade instrumentais, deixamos de contemplar outros saberes. Essa discussão será apresentada no tema sobre qualificação e empregabilidade. 


\subsection{TRABALHO E PROTEÇÃO LEGAL: A POLÍTICA DE COTAS NO BRASIL}

$\mathrm{Na}$ área da inclusão de pessoas com deficiência no trabalho, medidas de proteção legal passam a ser adotadas desde a primeira metade do século XX em diversos países.

Segundo Pastore (2000) a política de cotas teve sua origem na Europa, após a Primeira Guerra Mundial. A preocupação com a inserção de ex-combatentes de guerra no mercado de trabalho foi estendida às pessoas com deficiência por recomendação da Organização Internacional do Trabalho - OIT em 1944.

A Inglaterra e a Holanda foram os primeiros a aderir às cotas, seguidos da Espanha,

Grécia, Luxemburgo, Irlanda e Bélgica. Outros países adotam também o sistema de contribuição financeira, quando não é possível a contratação de pessoas com deficiência, ocorrendo variações nos percentuais exigidos, nas formas de punição e aplicação na esfera pública e privada. Dinamarca, Finlândia, Suécia, Estados Unidos, Canadá e Nova Zelândia rejeitaram esse sistema, com o argumento de que sugere que as pessoas com deficiência não possuem condições de competir no mercado de trabalho, o que subentende discriminação. (PASTORE, 2000)

No Brasil a lei prevê um percentual de cargos e empregos públicos para as pessoas com deficiência e define os critérios de sua admissão através da Lei Federal 8112 de 11 de dezembro de 1990. É um percentual que difere para cada município, estado, ou federação, ocorrendo concursos públicos que possuem $20 \%$ de vagas reservadas para pessoas com deficiência.

No setor privado, a adoção de cotas progressivas foi introduzida pela Lei $\mathrm{n}^{\circ} 8213$, de 24 de julho de 1991, que, no artigo 93 determina:

A empresa com 100 ou mais empregados está obrigada a preencher de $2 \%$ (dois por cento) a $5 \%$ (cinco por cento) dos seus cargos com beneficiários reabilitados ou pessoas portadoras de deficiência na seguinte proporção:

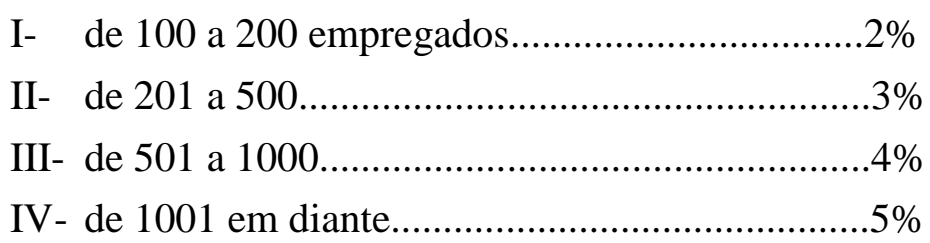


Essa legislação vem causando um grande impacto no meio corporativo empresarial gerando polêmica quanto a sua eficácia, envolvendo especialistas em inclusão, profissionais da área da administração e relações jurídicas de trabalho.

Em evento da Ordem dos Advogados do Brasil - OAB em São Paulo, em 2002, Dr Ricardo Tadeu, Promotor Público, esclareceu que uma política de proteção de mercado é uma ação afirmativa e deve-se cuidar para que não tenha caráter discriminatório contra as pessoas que não tenham deficiência, respeitando o princípio da igualdade. O sistema de cotas deve estar fundamentado em uma clara definição de pessoa com deficiência e em uma avaliação profissional objetiva frente às vagas existentes.

Outras opiniões argumentam contra tal medida pois representaria:

[...] uma discriminação às avessas [...] enquanto na vida real se combate agressivamente a sociedade por esta ser discriminatória contra as pessoas com deficiência, a lei discrimina contra outros segmentos da sociedade ao proteger os portadores de deficiência. (SASSAKI, 2003, p.148)

Reforçando essa posição, citamos a opinião de Carreira (in: SASSAKI, 2003, p.148):

Ao desejar garantir emprego para a pessoa portadora de deficiência o governo está exigindo a assinatura de um contrato de trabalho unilateral, que interessa apenas a uma das partes. Esse contrato estará condenado ao insucesso.

Para Pastore (2000, p.68):

[...] a legislação é da mais absoluta necessidade para levar a sociedade em geral, e as empresas em particular, a cumprir com sua responsabilidade social. Entretanto isso não basta.

Afirmando que "os empregadores precisam ser educados e estimulados", é a favor de uma combinação do tratamento jurídico e econômico dessa questão. Lembrando a Carta para o Terceiro Milênio, aprovada em 1999, ratificada pelo Congresso Mundial da Rehabilitation International, realizado no Rio de Janeiro, em 2000, demonstra a importância de uma diretriz política para a condução de um programa de ações afirmativas: 
Cada nação precisa desenvolver, com a participação das organizações de e para as pessoas com deficiência, um plano abrangente que tenha metas e cronogramas definidos para fins de implementação dos objetivos expressos nessa Carta. (Rehalitation International, 2000, apud PASTORE, 2000)

A Lei 8213/ 91 foi regulamentada pelo Decreto $n^{\circ} 3298$ / 99 em 20 de dezembro de 1999. A Instrução Normativa $n^{0} 20$ publicada em 20 de janeiro de 2001 define os procedimentos de fiscalização do trabalho das pessoas portadoras junto às empresas.

Uma ação intensiva do Ministério do Trabalho e Emprego-MTEpor meio de suas Delegacias Regionais de Trabalho, além do esforço do Ministério Público do Trabalho - MPT, atingem resultados numéricos de grande relevância.

A atuação da Delegacia Regional do Trabalho no Estado de São Paulo apresenta resultados altamente positivos de contratação efetiva de pessoas com deficiência pelas empresas privadas (JAIME; CARMO, 2005). A partir do processo de fiscalização, iniciado em 2001, no Estado de São Paulo, ocorreu um aumento de mais de $4.000 \%$ no número de colocações de pessoas com deficiência no mercado de trabalho, saltando de 601 pessoas com deficiência empregadas em 2001, para 28.815 no final do primeiro semestre de 2005. O total de 12 empresas contratantes passa para 3.525 empresas até o primeiro semestre de 2005 . A atualização desses números foi apresentada no início deste trabalho indicando que São Paulo atingiu a marca de 73.760 colocações até o ano 2007.

Os anais do seminário intitulado Profissionalização da pessoa Deficiente - Bolsa de Trabalho, realizado em São Paulo, em 29 de novembro de 1986, pelo Centro Nacional de Educação Especial - CENESP e Associação de Pais e Amigos dos Excepcionais - APAE de São Paulo, apresentam dados de contratação daquela época. Pesquisa realizada pela Secretaria do Estado das Relações do Trabalho indicou 25 candidatos colocados entre janeiro de 1985 e junho de 1986. Foram 261 vagas oferecidas, sendo 234 canceladas e 114 candidatos encaminhados. A representante da SERT afirmou: "o deficiente para a obtenção do emprego tem-se apresentado em condições pouco favoráveis para atender o mercado atual".

Complementou sua análise:

Para que possamos difundir o ingresso do deficente no mercado de trabalho pela sua capacidade laborativa e sua inclinação profissional, necessário se faz conscientizar o empregador e a sociedade em geral para aceitá-los, e isto só será possível quando as barreiras socioculturais e as demais forem rompidas. $(1986$, p.43) 
Os dados estatísticos revelam a importância das medidas políticas quanto à inserção da pessoa com deficiência no mercado de trabalho indicando a conquista de resultados quantitativos. Todavia a discussão da década de 80 sobre a falta de qualificação profissional, permanece presente nos dias atuais.

Contextualizando a inclusão das pessoas com deficiência no trabalho surgem outras variáveis como, tipos de deficiência, idade, escolaridade.

A Fundação Getúlio Vargas apresenta uma pesquisa coordenada por Néri (2003), intitulada Retratos da Deficiência no Brasil. Os dados oferecem um mapa da deficiência com base no Censo Demográfico do ano 2000 do Instituto Brasileiro de Geografia e EstatísticaIBGE. Pela primeira vez o Censo Brasileiro mostrou os números da deficiência, que fornecem parâmetros para as políticas públicas de atenção nessa área.

Segundo o IBGE, $14,5 \%$ da população brasileira é portadora de algum tipo de deficiência ou seja, 24,6 milhões de brasileiros na época do Censo apresentavam algum tipo de limitação sensorial, física ou mental, definidas dentro de parâmetros mais amplos

Em Retratos da Deficiência há uma distinção entre o grupo denominado PPD Pessoa Portadora de Deficiência e PPI - Pessoas com Percepção de Incapacidades, referindo àquelas que "possuem uma incapacidade de ouvir, andar ou enxergar, com deficiência física ou mental". Essa diferenciação foi adotada pelos autores da pesquisa, com o objetivo de destacar o grupo de pessoas com deficiências mais acentuadas (PPI) considerando que a metodologia utilizada pelo IBGE, baseou-se em critérios mais amplos para a categoria deficiência.

Na pesquisa da Fundação Getúlio Vargas a inclusão das pessoas com deficiência no trabalho em números significa 2, 5\% em emprego formal. E se considerarmos o espaço que as pessoas com deficiência ocupam no mercado de trabalho verificamos ser ele mais reduzido em relação à população sem deficiência Segundo Néri (2003), “dentro de 26 milhões de trabalhadores formais ativos, 537 mil são pessoas com deficiência, representando apenas cerca de $2,05 \%$ do total".

Em que condições vivem a grande parte das pessoas com deficiência? Referindo ao grupo das pessoas com incapacidade (PPI), ou seja aquelas que possuem uma deficiência mais severa, “[...] cerca de 41, 62\% das PPIs vivem em situação de miséria”. Mas o que surpreende no mapa da renda que a pesquisa traçou é que a taxa das pessoas com deficiência (envolvendo todos os níveis de limitação) consideradas miseráveis ainda é inferior à da população geral em 
situação da miséria. Esse dado indica que a discussão da exclusão de pessoas com deficiência configura o retrato mais amplo da exclusão social.

Em relação a inserção no trabalho Clemente e Celestini (2004) citam o Censo 2000, para destacar 15,22 milhões de brasileiros com algum tipo de deficiência dentro da faixa etária entre 15 a 59 anos (utilizando como critério o PEA- população economicamente ativa); desse grupo 7,8 milhões (51\%) estão empregados. Os autores apresentaram no mesmo gráfico a taxa de ocupação das pessoas sem deficiência: 59\%.

Verifica-se ser a diferença muito pequena entre o grupo de pessoas com e sem deficiência, o que leva a refletir sobre os critérios de definição da deficiência. Ao contemplar categorias mais amplas de deficiência, os dados do Censo 2000 restringem algumas conclusões dentro do âmbito das deficiências consideradas pela legislação para efeito da lei de cotas.

Pastore (2000), citando Carreira (1996), verificou pouco mais de 10\% da população portadora de deficiência "em idade de trabalho", conforme o autor, trabalhando formal ou informalmente na época do Censo de 1991. Estimativa da OMS previa um percentual menor de pessoas com deficiência - 10\%, 16 milhões de brasileiros na época.

Parece importante análises comparativas, que possam incluir uma reflexão cuidadosa quanto às diferenças de critérios adotados para a interpretação dessas pesquisas.

No Censo, realizado em 2000 a taxa de ocupação não possui diferença significativa em comparação com as pessoas sem deficiência. A questão do desemprego atingindo quase igualmente todos os segmentos envolve questões macro sociais relacionadas ao processo da globalização. A esse respeito citamos Mészáros (2006):

\footnotetext{
A tendência devastadora ao desemprego crônico hoje afeta até mesmo os países capitalistas mais adiantados. Ao mesmo tempo, também as pessoas ainda empregadas naqueles países têm de suportar a piora de suas condições materiais de existência, o que é admitido até mesmo pelas estatísticas oficiais. Pois o final da ascensão histórica do capital também trouxe consigo uma equalização para baixo da taxa diferencial de exploração. (p.27)
}

Nesse cenário, as pessoas com deficiência ainda lutam pelo reconhecimento de suas competências profissionais, exigindo esforços da sociedade e do governo para garantir-lhes igualdade de oportunidades. 
O mercado aponta para um grande obstáculo, que é a falta de qualificação, variável que atinge a todos, com e sem deficiência. Exige-se cada vez mais o aperfeiçoamento dos profissionais, cenário em que a situação das pessoas com deficiência é mais grave.

Dominado pela globalização da economia, o mundo corporativo busca resultados e um diferencial competitivo, a empresa depende da identificação de talentos e potenciais entre a mão de obra abundante gerada pela crise econômica e política.

Dessa forma, não se pode isolar da análise o processo da educação, sobretudo a profissional. Ela é fundamental para o ingresso das pessoas com deficiência no mercado de trabalho e sua inclusão econômica.

\subsection{QUALIFICAÇÃO PROFISSIONAL: COMPETÊNCIAS E EMPREGABILIDADE DA PESSOA COM DEFICIÊNCIA}

Entre as pessoas com deficiência, um contingente muito grande aguarda uma oportunidade de trabalho formal, porém, sem a qualificação exigida pelo mercado. Nesse cenário discute-se a flexibilização de critérios e o perfil profissional com vistas à ampliação das oportunidades de inserção da pessoa com deficiência, amparada pelo modelo das competências profissionais para o qual o mundo corporativo deslocou os saberes. Mais importante que o domínio dos conhecimentos, o indivíduo agora deve “[...] saber mobilizar conhecimentos e qualidades para fazer frente a um dado problema, ou seja, as competências designam conhecimentos e qualidades contextualizados". (MANDON, 1990, apud STROOBANTS, 1997).

$\mathrm{Na}$ perspectiva das competências, segundo Stroobants (1997) três categorias do conhecimento passam a ganhar evidência: saber, saber fazer, saber ser. A primeira categoria envolve os saberes formais, a segunda os saberes empíricos resultantes da experiência prática e a terceira os saberes sociais, de senso comum, envolvendo visão e interpretação do mundo, estratégias e raciocínios complexos. Citando Collins (1992), a autora refere que o saber ser ganha importância, invertendo a hierarquia convencional do saber.

Observa-se entre os sociólogos do trabalho uma preocupação com a valoração das competências "mobilizadas" na avaliação dos postos de trabalho. (STROOBANTS, 1997) Moraes (2001) refere que as definições de competência “[...] apresentam em comum o fato de não incluírem a idéia de relação social que está presente no conceito de qualificação". Comenta: 
Há alguns anos atrás, falava-se em qualificação e esta noção se relacionava àquela de negociação social, de convenção coletiva de trabalho. A tendência é atribuir-lhe o sentido de performance individual, o que indica um descolamento importante em direção à individualização crescente da apreciação dos assalariados. (MORAES, 2001, p.34)

A relação emprego e formação começa a se caracterizar pela ausência da relação entre as competências adquiridas na formação educacional e as requeridas pelo trabalho. A formação se dá no local de trabalho, tornando-o "qualificante, mobilizador das competências", segundo a autora. Ou seja, a competência pode ser validada sem a formação ou escolaridade necessária.

Diante de um novo modelo de organização, temos maior flexibilidade na divisão do trabalho, exigindo um profissional polivalente, que seja comunicativo, cooperativo, criativo, capaz de trabalhar em equipe. Essas competências genéricas ampliam seu valor, alterando as relações de trabalho, priorizando traços que identifiquem o trabalhador com a missão e a imagem da empresa. Esta exige também mais qualificação, para lidar com os novos modos de produção, alinhando autonomia, independência e empowerment.

A dificuldade de encontrar profissionais com deficiência qualificados vem gerando iniciativas de desenvolvimento de projetos de capacitação e treinamento, conduzidos por instituições de atendimento à deficiência e, mais recentemente pelas próprias empresas, ou resultantes de parceria entre as duas.

As alternativas educacionais de formação profissional sempre foram mais escassas para as pessoas com deficiência. Apesar de uma oferta maior nas décadas de 80 e 90, "todo esse conjunto de alternativas educacionais e profissionais espalhadas pelo Brasil e bem mais numeroso hoje do que no passado, não está capacitado a atender nem a demanda matriculada nem a demanda reprimida”. (SASSAKI, 1997)

Outro ponto importante é a qualidade da formação profissional., visto que muitos programas ditos profissionalizantes possuem estrutura informal e de curta duração, para ampliar a chamada empregabilidade. Cabe ao indivíduo empenhar-se para obter uma qualificação, ser empreendedor e buscar uma fonte de geração de trabalho e renda. Esta perspectiva domina tanto os desempregados como as pessoas com deficiência, historicamente excluídas do acesso à educação e ao trabalho.

Assim o cenário da empregabilidade da pessoa com deficência exige rever o papel da escola como formadora e portanto a responsabilidade do Estado para garantir o acesso à educação. Muitos programas servem apenas como iniciação profissional oferecendo a 
oportunidade de assimilar alguns aprendizados instrumentais, acabando por reforçar a responsabilidade das pessoas com deficiência pela mudança do cenário de exclusão.

Os empregadores querem e necessitam contratar pela produtividade e competência, e as pessoas com deficiência enfrentam a falta de qualificação para obter melhores oportunidades de trabalho.

A nenhuma das partes interessa uma postura paternalista, pois a participação e a eficiência representam o anseio tanto das pessoas com deficiência como dos empresários.

No entanto é urgente uma ampla discussão para evitar uma nova discriminação: ao reservar-lhes vagas, a sociedade pode também destinar-lhes um percurso pouco promissor de desenvolvimento de sua autonomia e crescimento profissional. As pessoas com deficiência têm o direito de recuperar o itinerário da sua formação educacional e profissionalizante.

Empresas consideradas competentes, com visão de futuro, exercitando valores de responsabilidade social corporativa, entendem a diversidade como forma de agregar valores e diferenciar seus produtos. A linguagem de mercado infelizmente pode posicionar a pessoa com deficiência como mais um produto. $\mathrm{O}$ modelo capitalista gera extrema competitividade e desigualdade social exigindo observar criticamente as mudanças no mundo do trabalho e suas contradições quanto à aceitação e respeito às diferenças.

A educação profissional, como parte estratégica das políticas de acesso e permanência no trabalho, deve ter prioridade dentro do programa de ações afirmativas frente à deficiência. Para isso é importante um alinhamento crítico das políticas públicas de educação profissional aplicadas à sociedade em geral e às pessoas com deficiência em particular. 


\section{A PESQUISA}

A pesquisa propôs um estudo de natureza qualitativa acerca de um grupo de pessoas com deficiência incluídas no mercado de trabalho. Segundo Minayo (2006) esta abordagem é a que melhor se conforma “[...] a investigação de grupos e segmentos delimitados e focalizados, de histórias sociais sob a ótica dos atores, de relações e para análise de discursos e documentos".

O método qualitativo é o que se aplica ao estudo da história, das relações, das representações, das crenças, das percepções e das opiniões, produtos das interpretações que os humanos fazem a respeito de como vivem, constroem seus artefatos e a si mesmos, sentem e pensam. (MINAYO, 2006, p.57)

Considerando que, pessoas com deficiência apresentam particularidades no processo de inclusão, a pesquisa pretendeu investigar os aspectos qualitativos desse processo na escola e no trabalho. Os resultados não podem ser generalizados, mas constituem um recorte histórico e cultural na perspectiva da pessoa com deficiência.

A escolha das técnicas e instrumentos de coleta de dados recaiu sobre as narrativas de vida. O eixo desse registro autobiográfico foi o relato das experiências de inclusão ou de exclusão, vividas pelos sujeitos da pesquisa, à luz dos princípios da autonomia, independência e empoderamento já discutidos anteriormente.

Depoimentos, memórias pessoais, marcas da subjetividade constituem um material que, embora com categorias pouco generalizáveis, geram um discurso valioso de conteúdos com significados singulares para cada sujeito.

$\mathrm{O}$ interesse deste trabalho foi apreender do processo individual os significados construídos culturalmente pelos sujeitos como propõe a Psicologia Cultural (LEME, 2004). Citando as idéias de BRUNER $(1990,1996)$ a autora aponta os aspectos sociais e relacionais da identidade, individualidade, contidas na concepção do si mesmo cultural. Nessa visão a narrativa autobiográfica representa uma forma de acesso aos significados construídos pelo indivíduo e pela cultura, no presente e em sua história, na perspectiva de compreensão da cultura como construção histórica e coletiva. Ao ouvirmos as histórias de cada um, ouvimos também a história de uma época, de uma sociedade.

Por meio da narrativa analisam sua própria história de vida. O interlocutor/ pesquisador, ao selecionar quem entrevistar e o que perguntar, pode tecer uma rede de significados sobre a temática investigada. 
A história de vida pode ser a melhor abordagem para se compreender o processo de socialização, a emergência de um grupo, a estrutura organizacional, o nascimento e o declínio de uma relação social e as respostas situacionais a contingências cotidianas. (MINAYO, 2006, p.154)

A teoria de Vygotsky (1998) propõe uma visão dialética do que é humano, entendendo que o homem é ao mesmo tempo produto e agente ativo de seu meio, cria o contexto social e é influenciado por ele. É nessa interação dialética que o homem se constrói e se humaniza. O inato não é suficiente para o indivíduo tornar-se humano. É necessário o ambiente social. Organismo e meio atuam em reciprocidade, sendo fundamental a interação social para que o indivíduo se desenvolva,. O desenvolvimento não é previsível, linear, universal, mas diretamente relacionado com o contexto sociocultural, continuamente reorganizado pelo indivíduo. Ao começar as interações com o contexto cultural, a criança passa a incorporar ativamente as formas de comportamento humano, entrelaçando os processos elementares de natureza biológica com os processos superiores de origem sociocultural, mediados pelo outro.

Nessa perspectiva dialética, situo a pessoa com deficiência como um sujeito ativo, que vivencia os movimentos de inclusão da sociedade, para quem volto o meu olhar e a minha escuta.

Ao eleger a metodologia de pesquisa estou ciente de que o enfoque epistemológico não está voltado à investigação de relações causais, mas de "relações entre o fenômeno vivido e aquele que vivencia o fenômeno", como aponta Teixeira (2005). A interpretação será o fundamento da compreensão do que se pretende estudar. Para pensar a deficiência e a inclusão social, partiu-se das histórias dos principais protagonistas do processo, buscando pontos de divergência ou de convergência dentro da singularidade das trajetórias de vida na escola e trabalho dos sujeitos.

\section{Sujeitos da amostra}

Realizei a pesquisa de campo com 07 sujeitos que possuem algum tipo de deficiência, física, auditiva, visual ou intelectual, encontrando-se todos incluídos no mercado formal de trabalho. Elegi como critérios para definir a amostra a idade, o grau de escolaridade e trabalho com vínculo empregatício. Excluí sujeitos que trabalham no mercado informal ou em trabalho institucional, porque meu interesse foi pelas pessoas incluídas, com vida autônoma e independente, do ponto de vista econômico e social. O grau de escolaridade 
mínimo foi o ensino médio, completo ou incompleto, pois considerei somente pessoas com deficiência que conseguiram êxito na trajetória escolar. A exceção foi o sujeito com deficiência intelectual, que pela natureza da própria deficiência estabeleceu-se um nível de escolaridade correspondente ao ensino fundamental incompleto, assim como possui certa limitação de autonomia.

A amostra foi obtida a partir do banco de dados da GELRE, empresa de consultoria de Recursos Humanos que possui uma divisão específica para a colocação de pessoas com deficiência nas empresas, além de contato direto com familiares e indicação de profissionais que atuam na área da deficiência. A participação com adesão espontânea, pretendeu garantir o interesse e a disponibilidade para relatos pessoais.

\section{Coleta de dados}

A pesquisa de campo por meio de entrevistas semi-estruturadas pretendeu proporcionar "a liberdade de percurso", conforme observam Lüdke e André (1986).

Para o registro utilizei dois formulários: uma ficha com dados de identificação dos sujeitos participantes (Anexo 1) a ser preenchida pelo entrevistador no início da entrevista, e um roteiro de entrevista semi estruturada (Anexo 2).

$\mathrm{O}$ roteiro procurou investigar temas de vivência escolar, grupos de convívio social e a integração nos locais em que já trabalhou ou trabalha, como um registro autobiográfico, a partir das experiências de inclusão ou exclusão no contexto vivido pelos sujeitos pesquisados.

As entrevistas ocorreram em locais reservados, utilizando-se sala de consultório particular, da Associação dos Surdos e da empresa GELRE em horários previamente agendados. Além da pessoa entrevistada e do entrevistador, apenas em dois casos houve a presença de outras pessoas: uma intérprete de Língua Brasileira de Sinais - LIBRAS durante a entrevista com um surdo, e os pais do jovem com deficiência intelectual para uma complementação de dados após a coleta do seu depoimento individual.

Validei o instrumento de coleta de dados realizando previamente uma entrevista para testar o conteúdo da ficha e roteiro, que sofreram alguns ajustes.

O tempo de duração das entrevistas manteve-se ao redor de 80 a 90 minutos após preencher as fichas com os dados de identificação do sujeito, como nome, idade escolaridade, instrução e profissão dos pais, escolas freqüentadas, informações da deficiência. Todos os 
relatos foram gravados com anuência do entrevistado e posteriormente transcritos para análise.

\subsection{RESULTADOS}

Como primeira etapa no estudo dos resultados realizei uma análise prévia do material coletado, agrupando informações que, somadas aos dados de fichas de registro, configurou o perfil de cada pessoa entrevistada. Apresento uma descrição geral da amostra dos sujeitos da pesquisa, seguida dos perfis individuais.

Os perfis individuais seguem a ordem cronológica da realização das entrevistas escolhendo-se para cada sujeito um nome aleatório para resguardar sua identificação. Omitiuse os nomes dos locais de trabalho, referindo-se apenas ao tipo e segmento de empresa, considerando-se o procedimento necessário ao sigilo de alguns dados.

\subsubsection{Perfil da amostra}

A pesquisa foi realizada entre os meses de setembro a novembro de 2007 , e as pessoas entrevistadas na época se encontravam na faixa etária entre 24 à 42 anos, sendo 05 do sexo masculino e 02 do sexo feminino.

A maioria é solteira, sendo dois divorciados e um casado. Todos residem com a família de origem inclusive os divorciados, com exceção do sujeito casado que mora com a esposa e os filhos. Todos são residentes da região da grande São Paulo, morando na capital ou municípios próximos a ela como Guarulhos, Diadema e São Bernardo do Campo.

Os locais de trabalho concentram-se na mesma região de moradia. Um sujeito trabalha no setor público e os outros em empresas privadas pertencentes a segmentos diversificados: industria de agronegócios, química, automobilística, equipamentos de automação e serviços, sendo quatro delas multinacionais.

Quanto ao grau de escolarização, o jovem com deficiência intelectual possui ensino fundamental incompleto correspondendo ao nível de $5^{\circ}$ série; uma pessoa possui ensino médio, três freqüentaram curso técnico nas áreas de Processamento de Dados, Contabilidade e Administração, sendo que um deles cursa atualmente a faculdade de Educação Física; outros dois concluíram o ensino superior em Direito e Ciências da Computação. 
Quanto ao tipo de deficiência 02 possuem deficiência física, 02 deficiência auditiva sendo um oralizado e outro com surdez congênita profunda, 2 possuem deficiência visual, um com cegueira e outro com baixa visão, e 01 apresenta deficiência intelectual.

Levantou-se também o grau de escolarização dos pais: entre as mães dos entrevistados, 01 é analfabeta, 01 possui ensino fundamental, 03 ensino médio e 02 ensino superior. Em relação à atividade ocupacional 04 mães nunca trabalharam fora, 01 foi vendedora autônoma, 01 trabalha com vendas informais de cosméticos e 01 mantém atividade profissional no ramo do comércio. Entre os pais 01 possui ensino fundamental incompleto, 04 ensino médio ou técnico e 02 ensino superior. Nesse grupo 02 são falecidos, 02 aposentados e 03 mantém atividade profissional. Os pais atuam ou atuaram nas profissões de carpinteiro, ferramenteiro, alfaiate, projetista, comerciante, advogado e jornalista

\section{Sujeito $n^{\circ} 1$}

Ana possui 24 anos, seu grau de escolaridade corresponde ao ensino médio completo e começou a trabalhar como autônoma, vendendo lanches em um trailer da irmã. Conseguiu sua primeira oportunidade de contrato efetivo com 22 anos trabalhando por quase 2 anos como agente de atendimento em empresa de prestação de serviços de recursos humanos; um mês antes da entrevista foi contratada como auxiliar administrativo em empresa multinacional.

Possui deficiência física, apresentando quadro de deformidade congênita em membros inferiores: "pés tortos". Locomove-se sem apoios ortopédicos, mas com importante alteração na marcha. Fez poucos tratamentos pela falta de recursos financeiros e de especialistas na sua cidade. Natural de Ubaetaba - BA encontrou dificuldade de atendimento em hospitais de Itabuna, Ilhéus e mesmo em São Paulo quando foi trazida pela mãe para tratamentos especializados. Não fez cirurgia corretivas dos pés tortos e ainda há poucos anos quase foi vítima de imperícia médica, quando recomendaram a amputação do membro inferior devido a uma infecção. Seu pai é carpinteiro, estudou até a quinta série do ensino fundamental e sua mãe é analfabeta. Possui 6 irmãos que moram na Bahia com os pais e Ana mora em Guarulhos há quase 9 anos com a irmã casada. Em relação ao processo de escolarização sempre estudou em classe comum de escolas públicas. $\mathrm{Na}$ infầncia freqüentou creche municipal e até a quinta série do ensino fundamental estudou em escola estadual na Bahia. Da sexta série em diante até o ensino médio freqüentou escola estadual em Guarulhos, SP 


\section{Sujeito $n^{\circ} 2$}

Paulo tem 27 anos é formado em Direito, e trabalhou em áreas diversas como estagiário da Procuradoria Geral do Estado e escritório de advocacia. Foi gerente de loja do ramo alimentício, auxiliou os negócios do pai e há um mês da data da entrevista, foi contratado como auxiliar administrativo por uma empresa multinacional, localizada em Guarulhos.

Possui deficiência auditiva bilateral em grau moderado, de causa congênita com fator hereditário. Paulo possui uma ótima oralidade, utilizando aparelho auditivo digital. Fez tratamento fonoaudiológico particular desde os 5 anos de idade até o início da adolescência. Atualmente faz só um acompanhamento. Os pais não apresentam a deficiência e dois irmãos manifestaram o mesmo quadro, sendo um deles recentemente.

Natural de São Jose dos Campos, é solteiro atualmente reside em Arujá município próximo de São Paulo e Guarulhos. Mora com a família dois irmãos e uma irmã. O pai é comerciante com grau de instrução em nível de ensino médio e a mãe formada em Letras, também é comerciante.

Paulo formou-se há 2 anos em uma Faculdade particular de Guarulhos e na infância freqüentou escola pública estadual durante as 3 primeiras séries do ensino fundamental. Mudou para escola particular concluindo a oitava série e depois fez o a $1^{\circ}$ e a $2^{\circ}$ série do ensino médio no Colégio Objetivo; a última série no Colégio Alpha. Sempre foi aluno de classe regular e somente por 2 meses na $1^{\circ}$ série do ensino fundamental, freqüentou em paralelo uma escola especializada para surdos orientado pela professora da sala comum, mas não se adaptou ao ensino por LIBRAS e sua mãe insistiu que permanecesse só na sala comum.

\section{Sujeito $n^{\circ} 3$}

Márcia tem 34 anos, concluiu o ensino superior em Ciências da Computação, mas nunca exerceu a profissão. Sempre atuou na área de atendimento, encontrando-se há 7 anos em empresa de consultoria de recursos humanos, onde iniciou como assistente de atendimento ao cliente e foi promovida há 2 anos para o cargo de coordenadora da área. Trabalhou anteriormente como operadora de rádio, operadora de telemarketing e recepcionista em empresas de telecomunicação. 
Possui cegueira, deficiência adquirida ao nascimento decorrente de falha de atendimento hospitalar: na condição de prematuridade a elevação do nível de oxigênio atingiu a retina.

Natural de Montevidéo - Uruguai, encontra-se no Brasil desde os 3 anos de idade, morando a maior parte desse tempo em São Paulo e atualmente reside em Diadema, município próximo à capital. Mora com a mãe, a irmã mais velha e o irmão mais novo. O pai falecido há poucos anos, era ferramenteiro com nível escolar de ensino médio. A mãe já trabalhou como vendedora autônoma possui ensino médio e atualmente não trabalha.

Márcia freqüentou escola maternal em Montevideo, no único colégio da cidade na época. Quando mudou-se para o Brasil, ingressou imediatamente em uma instituição especializada para crianças cegas no bairro em que morava, o Instituto Padre Chico. Estudou todo o período do ensino fundamental nessa escola especial e a partir do ensino médio, freqüentou escola regular do estado. Fez o $1^{\circ}$ colegial na Escola Estadual Professor Caetano de Campos e as outras séries na Escola Estadual Professor Alexandre de Gusmão. Cursou a Universidade São Marcos em São Paulo Graduando-se em Sistemas de Informação.

\section{Sujeito $n^{\circ} 4$}

José tem 42 anos possui formação técnica em contabilidade e processamento de dados. Interrompeu curso superior na área de Marketing e outro de Tecnologia. Trabalhou em negócio próprio, foi encarregado administrativo em empresa de automação e há 2 anos é funcionário em empresa de fabricação de elevadores, exercendo a função de assistente administrativo no setor de compras. Possui deficiência física seqüela de poliomielite adquirida no $1^{\circ}$ ano de vida. Apresenta alteração na marcha devido ao comprometimento motor parcial no membro inferior locomovendo-se sem necessidade de apoios ortopédicos. Fez tratamento clínico intensivo em instituição especializada de São Paulo, a AACD-Associação de Assistência à Criança Defeituosa durante sua infância até o início da adolescência, e a família também buscou outros hospitais de referência para cirurgias corretivas.

Natural de São Paulo seu pai já falecido era projetista, com escolaridade correspondente ao ensino médio. A mãe possui nível de escolaridade de ensino médio e não trabalha fora. Atualmente é separado, não possui filhos e mora com a mãe e o irmão. 
José sempre freqüentou escola regular. No ensino fundamental foi aluno da Escola Estadual de Primeiro Grau Regente Feijó, no bairro da Freguesia do Ó. Cursou o ensino técnico em escola regular particular, denominada Colégio Padre Anchieta. Iniciou curso superior freqüentando dois anos na Universidade Paulista o curso de Marketing e um ano de Logística no Centro Educacional Flamingo.

\section{Sujeito $n^{\circ} 5$}

Henrique tem 38 anos e sua formação educacional corresponde ao nível técnico de auxiliar administrativo. Foi contratado há 2 meses, da data da entrevista, por uma empresa multinacional do ramo automobilístico como assistente administrativo no setor de compras. Anteriormente trabalhou durante 3 anos e meio como auxiliar de escritório na DERDepartamento de Estradas e Rodagem e já foi ajudante geral em indústria durante 5 anos. Possui deficiência visual congênita decorrente de toxoplasmose, apresentando baixa visão. A acuidade visual é 0,1 em ambos os olhos. Escreve e faz leitura à tinta e utiliza apoio de telelupa para visão à distância. Iniciou tratamento clínico com especialista mais ou menos aos 18 anos, quando pela primeira vez recebeu o diagnóstico mais preciso de sua deficiência, passando a utilizar a telelupa. Esse encaminhamento foi realizado pela professora do ensino médio.

Natural de Minas Gerais mudou-se para São Paulo com mais ou menos 16 anos. Casado, reside atualmente em São Bernardo do Campo com a esposa e duas filhas. A esposa eventualmente trabalha como manicure. Henrique é a única pessoa com deficiência na família.

Seu pai é aposentado tinha o ofício de alfaiate e soldador com escolaridade correspondente ao ensino médio. A mãe possui nível de escolaridade de ensino fundamental trabalha eventualmente com vendas de cosméticos.

Henrique sempre freqüentou ensino regular em escolas públicas estaduais. No ensino fundamental e ensino médio foi aluno da Escola Estadual Professor Filinto Muller, no município de Diadema. Cursou o ensino técnico de auxiliar de administração na Escola Técnica Lauro Gomes. 


\section{Sujeito $n^{\circ} 6$}

Marcos tem 28 anos e seu nível de escolaridade corresponde ao ensino fundamental incompleto. Trabalha há 9 anos como mensageiro interno em uma grande empresa multinacional da área de agronegocios, e em agosto de 2007 foi efetivado. Possui deficiência intelectual apresentando um quadro de paralisia cerebral com leve seqüela na área motora, caracterizando uma ligeira incoordenação motora global e deficiência na articulação das palavras. Independente nas rotinas diárias, utiliza transporte coletivo apenas para ir ao trabalho, sendo normalmente acompanhado pelos amigos ou familiares para outros deslocamentos. Os pais foram orientados desde o seu nascimento e freqüentou programas de estimulação, acompanhamento e reforço psicopedagógico em clínicas especializadas.

Mora com os pais sendo o segundo filho do casal, possuindo uma irmã mais velha. $\mathrm{O}$ pai possui curso superior e jornalista e a mãe ensino médio, não trabalha fora.

Marcos sempre estudou em escola especializada freqüentando desde a educação infantil ate o ensino fundamental, o colégio Essência Equipe de Ensino, e na adolescência o Centro de Preparação para o Trabalho da APAE - Associação de Pais e Amigos de Excepcionais de São Paulo. Paralelamente passou por clinicas de reabilitação como a AACD Associação de Assistência a Criança Defeituosa, a Clínica URI para tratamento com profissionais especializados, como a fonoaudióloga, fisioterapeuta, psicopedagoga. Desenvolveu-se em programa de escolarização ate o nível de sexta serie. É alfabetizado, encontrando limitações na área de cálculo.

\section{Sujeito $n^{\circ} 7$}

Alex tem 37 anos possui formação técnica em processamento de dados e atualmente cursa a faculdade de Educação Física. Contratado há quase 1 ano como funcionário comissionado em um órgão público municipal voltado às questões da pessoa com deficiência, exercendo o cargo de assistente técnico. Anteriormente trabalhou por 3 anos como terceirizado da AVAPE - Associação para Valorização da Pessoa com Deficiência, na função de operador de micro computador. Possui experiência em empresa da área de informática, iniciando sua vida profissional como estagiário da área de programação em empresa estatal de energia. 
Alex apresenta surdez congênita, em grau profundo e bilateral, decorrente de rubéola adquirida pela mãe durante a fase gestacional. Já utilizou aparelho auditivo mas dispensou-o por não se adaptar. Faz uma boa leitura labial e comunica-se por LIBRAS. Durante muito tempo fez atendimento clínico particular com fonoaudióloga.

Natural de São Paulo voltou a morar com os pais desde que se separou da esposa há 4 anos e tem um filho. Alex é a única pessoa com deficiência na família. O pai é advogado aposentado e a mãe formada em pedagogia mas não exerce a profissão.

Alex sempre freqüentou escolas particulares, iniciando educação infantil em escola comum, com 6 anos de idade. Com 7 anos foi transferido para uma escola especializada para surdos, a DERDIC - Divisão de Educação e Reabilitação dos Distúrbios da Comunicação, onde completou o ensino fundamental. Fez em seguida um curso técnico de Processamento de Dados no Colégio Radial. Complementou sua formação com mais um curso na SOS Computadores, escola de informática. Retomou os estudos há 3 anos sendo aluno da faculdade de Educação Física na UNISANTANA em São Paulo.

\subsection{ANÁLISE DOS RESULTADOS}

Após uma exaustiva leitura das entrevistas, retomamos os objetivos propostos e delimitamos alguns recortes dessas histórias de vida que constituíssem unidades relevantes para nossa investigação, definindo-se aos poucos as possíveis categorias de análise. Coerente com a escolha da abordagem qualitativa e o uso da história oral como método de pesquisa, buscamos nas narrativas seus significados através de uma análise temática.

É o momento qualitativo da investigação a partir da análise de conteúdos, definida segundo Bardin (1977) como:

Um conjunto de técnicas de análise das comunicações visando obter, por procedimentos sistemáticos e objetivos de descrição de conteúdos das mensagens, indicadores (quantitativos ou não) que permitam a inferência de conhecimentos relativos às condições de produção / recepção (variáveis inferidas) destas mensagens. (BARDIN, 1977, p.42)

Os relatos foram reconstruídos na forma de texto escrito tomando-se um cuidado para transformar a linguagem informal em expressão escrita. Deu-se atenção à forma gramatical, suprimindo-se as repetições, gírias, procurando manter o estilo pessoal das narrativas dos sujeitos. 
Optou-se em incluir os depoimentos dos pais de Marcos, como fonte complementar de informações coletadas considerando que sua deficiência intelectual em alguns momentos restringiu o acesso aos temas tratados.

A transcrição da entrevista realizada com a pessoa surda manteve a mesma referência utilizada pela intérprete, que se dirigia a fala do entrevistado sempre utilizando a terceira pessoa do singular.

Quanto a postura na comunicação dos sujeitos na entrevista, observamos em geral uma fala expressiva, denotando interesse em expor suas idéias e relembrar fatos vivenciados em momentos significativos de suas vidas. Encontramos uma maior dificuldade de intelegibilidade na fala de Marcos devido ao seu déficit de articulação oral. Observou-se uma fala mais suscinta e objetiva de José, ao compararmos com outros depoimentos mais ricos tanto na expressão emocional como nos detalhes dos conteúdos das lembranças, opiniões e posicionamentos pessoais.

Diversas foram as reações durante as narrativas, seguidas algumas vezes de forte carga emocional. Houve momentos de relatos espontâneos, alegres, outros mais graves, compenetrados, sérios, críticos, eventualmente reação de irritação ou indignação, envolvendo passagens delicadas, vivências marcadas ora por sentimentos de aceitação e inclusão ora de discriminação e exclusão.

Das narrativas obtidas elegemos algumas categorias de análise, organizando a fala dos sujeitos ao redor das seguintes temáticas: vida escolar, o lugar da família, inserção no trabalho, cotidiano social, reflexões sobre a inclusão. Em cada uma das categorias temáticas, organizamos subcategorias para sistematizar os depoimentos:

- vida escolar apresenta os caminhos percorridos na escola regular ou especializada, a percepção dos sujeitos desses contextos diversos trazendo suas experiências de aprendizado e convivência com colegas e professores.

- o lugar da família traz a vivência com pais e irmãos desde que a deficiência foi identificada e o papel que esse núcleo de apoio exerceu no processo de inclusão dos sujeitos entrevistados.

- inserção no trabalho traz os relatos da vida profissional, a integração no ambiente de trabalho incluindo medidas de acessibilidade e relacionamento interpessoal e a opinião sobre a lei de cotas. 
- cotidiano social reúne as lembranças de convívio na infância e experiências de sentir-se socialmente incluído ou excluído, trazendo fatos marcantes que ficaram na memória desses sujeitos.

- reflexões sobre a inclusão apresenta as opiniões e o olhar sobre o movimento da sociedade para incluir as pessoas com deficiência.

\subsubsection{Vida escolar}

\section{A escola regular e a escola especial}

No início deste trabalho levantamos uma questão: somente a oportunidade e o acesso à educação podem garantir a formação e educação profissional das pessoas com deficiência e incluí-las no mundo do trabalho. Os sujeitos da pesquisa foram selecionados de acordo com este critério e todos tiveram esse percurso garantido, embora os caminhos tenham sido diversos e as experiências também.

Seja pela escola regular ou especializada da rede pública ou privada, a escolha por um desses caminhos revela a influência de diversos fatores envolvendo desde o acesso à informação como também de enfrentamento do preconceito, além da orientação de profissionais da educação e da saúde e, principalmente, da natureza e intensidade da deficiência, como veremos pelos depoimentos que seguem.

Ana nasceu com uma deformidade congênita e assim como José, que apresenta seqüela de paralisia infantil, ambos locomovem-se com total independência. Henrique possui baixa visão. Todos eles freqüentaram em épocas e locais bem diferentes escolas públicas regulares. Henrique e José iniciaram sua vida escolar na década de 70 o primeiro no interior de Minas Gerais outro em São Paulo, enquanto Ana entrou na escola no final da década de 80 no interior da Bahia.

Aí tinha que procurar escola... Ela (mãe) falava que tinha vez que nos médicos sofria um pouco de preconceito com as outras mães que viam, achavam absurdo aquilo (a deformidade nos pés). Mas eu tive muita sorte porque ela não foi uma mãe de sentir vergonha da filha! De não esconder, tipo por na escola especial... Eu comecei a ir na escola a partir dos 4 anos. A gente ficava na creche e depois fui para o prezinho. (Ana) 
Sempre estudei em escola comum desde a primeira série. Foi normal. As professoras tinham um cuidado a mais digamos assim. Acho que elas ficavam me observando mais, meus movimentos, nesse sentido de dar mais atenção. (José)

A minha mãe me matriculou simplesmente, ela não tinha informação. Ai foi o contrário. A escola que chamou meus pais e falou, ele tem uma dificuldade, não consegue enxergar, tem que ver de perto, e ai foram trabalhando comigo essa parte, e eu fui ao médico. (Henrique)

Paulo que apresenta surdez em grau moderado e uma oralidade bem desenvolvida, freqüentou escola particular após uma breve passagem em uma sala especial para alunos surdos. Sua mãe insistiu pela permanência em sala comum à revelia da professora. Paulo referiu no entanto que enfrentou dificuldades. Iniciou a vida escolar no final da década de 80 .

Tinha duas professoras na escola que achavam que eu tinha que ir para uma escola para surdos. Uma escola especializada que tinha sinais, LIBRAS. Aí eu acabei saindo da sala regular e minha mãe me transferiu. Era na mesma escola, só que tinha um parte que tinha uma sala especial. Dai eu acabei acompanhando um tempo, nessa parte especifica, a professora tentava ensinar sinais. Minha mãe sentiu que eu podia acompanhar, falou que não, bateu o pé e acabei voltando. Foi por insistência da minha mãe. Ela conversou com umas fonoaudiólogas e elas achavam que devia ficar na sala regular, comum. Dai eu tentava ficar na carteira da frente porque eu perdi muita coisa Eu perdi muito. (Paulo)

Nos casos em que a deficiência situou-se em limiares mais profundos, requerendo métodos especializados de ensino, o processo de escolarização por meio da escola especial foi a opção das famílias dos sujeitos pesquisados. Pessoas como Márcia que possui cegueira foi alfabetizada em Braille, Alex que é surdo freqüentou ensino por Libras, Marcos que tem deficiência intelectual associada a um déficit motor leve recebeu um atendimento educacional mais individualizado, e assim todos eles freqüentaram instituições especializadas ou escola com programação alternativa de ensino. No caso da Márcia a família originária de Uruguai, optou pela mudança de país em busca de recursos especializados na educação de cegos. 
Entrei na escola com 2 anos quando ainda morava no Uruguai. Lá não tem escola especial e então meu pai foi orientado. Ele falou: se eu tiver condições vai ser melhor viajar para outro país porque aqui não vai ter estudo pra ela. O médico quando falou para minha mãe que eu não ia enxergar, contou de uma criança que morava na rua dele era super desenvolvida que andava de bicicleta Minha mãe não acreditou. Ele falou: ela pode estudar, pode se formar. Então esse médico indicou esse instituto e essa pessoa do instituto indicou ou os Estados Unidos, ou o Brasil... Viemos pra cá entrei no Padre Chico que é um colégio especial. Tinha 3 anos e vim direto pro colégio. (Márcia)

A primeira escola de Alex era particular, em Pinheiros. Tinha 6 anos, em 1977... Ele ia junto com o irmão dele, e o irmão foi até a oitava série. Alex ficou nessa escola só 4 meses, não se adaptou. Na escola de ouvinte ele sentia que tinha preconceito. Porque quando ele brincava gritava muito porque é uma cultura dele, do surdo, ele não tem controle do som da voz. Os ouvintes ficavam provocando, ele acabou se fechando $e$ ficando isolado. Quando ele fazia LIBRAS, fazia sinais, riam dele. A mãe percebeu e tirou ele dessa escola. Ele entrou na DERDIC que é uma escola conveniada com a PUC. Ficou muito feliz porque ele pode encontrar a língua nas mãos, conseguiu se comunicar e o importante é a comunicação. No caso do surdo precisa se comunicar em LIBRAS que é a língua deles. Até a oitava série ele ficou na DERDIC. (intérprete de Alex)

Ele começou em uma escolinha, escola pequena, particular. Quando foi para Essência tinha 6 anos. A gente procurou escola que não fosse só pra deficiente... Acho que a URI indicou a Essência. Porque não tinha escola. Só para problemas mais graves. O médico falou que o nível dele, não era para colocar em escola com muito problema. Porque se a criança está em desenvolvimento e ela vai para uma escola de criança com muito problema ela cria problema, não evolui. Então era difícil achar uma escola. Ele estava no limite na parte intelectual. Na parte de estudo tinha atraso pequeno e na parte motora foi recuperando. (pais de Marcos)

\section{A vivência em escola especializada}

Em seus depoimentos Márcia, Alex e os pais de Marcos referem à escola especial relevando a qualidade do seu projeto pedagógico. A valorização dos recursos clínicos e 
educacionais, a estimulação da socialização oferecidas pelas instituições especializadas é claramente observada na fala dos entrevistados.

O Padre Chico é um colégio que tem de tudo. Tanto as matérias normais regulares como natação. E ai que eu gostei de música, porque tinha aula de violão, aula de piano, flauta, coral. A banda do Padre Chico abria os desfiles do 7 de setembro, banda mesmo, não era fanfarra Viajava para o interior para se apresentar em outros locais também. Cheguei a ficar um tempo na banda, mas fiquei mais no coral, tocava piano, e tinha outras atividades de educação física, natação. Tinha gincana normal, tudo que tinha de atividades para quem enxerga como corrida do saco, corrida de colher com a batata tinha tudo (igual). Então por isso eu tinha mais facilidade para brincar com as crianças da minha rua. Porque eu já tinha aquela mobilidade de uma vida normal no colégio. (Márcia)

Na DERDIC os alunos são amigos até hoje. Já faz 30 anos nunca se separaram e ele ama esses amigos. De segunda e quarta se encontram para jogar futebol, são os veteranos. Naquela época todos os dias jogavam futebol juntos... eram viciados em futebol. Ele lembra também dos professores, reclamavam do cheiro deles porque eles voltavam suados, reclamavam muito! Ele tem saudades dessa época! No banheiro combinavam de gritar dentro do banheiro, porque isso é uma cultura do surdos, gritarem. Os professores se assustavam mas depois se acostumaram e já não ficavam bravos. (intérprete de Alex)

A Essência tinha uma proposta já alternativa. Era difícil achar uma escola totalmente comum, eles não iam aceitar. Fomos direto para essa escola, porque ficamos naquela dúvida. Vai para uma escola especializada? Mas totalmente especializada ficava ruim Onde achar o meio termo? Muito dificil. A Essência tinha poucos alunos em cada classe. Paralelamente a escolinha tinha um atendimento na clínica. Tinha fono, trabalhava a parte tátil, toda estimulação. Fez muito tratamento. (pais de Marcos)

No caso de Marcos a continuidade em escola especial foi mantida até ele conseguir uma qualificação profissional e freqüentou um programa na APAE- SP com essa finalidade. 
No colégio Essência chegou um ponto que não avançava mais e tinha que pensar no futuro. Ai a gente levou para fazer um teste na APAE. Lemos uma reportagem que a APAE se preocupava com essa coisa de trabalho. Ai passou pela avaliação e estava começando um programa novo, Centro de Preparação para o Trabalho - CPT. Tinha a parte de alfabetização e também de encaminhamento para o trabalho. Tinha estágios na padaria, ele fez tudo lá. Antes de ir para a empresa, ele fez estágio em estacionamento, ficava anotando os carros. O CPT colocava na prática! Na APAE eles aprendiam natação, o pessoal estimulava essa parte também. (pais de Marcos)

Marcos traz muitas lembranças positivas de sua vivência escolar, dos conteúdos aprendidos, valorizando a atuação de seus professores e principalmente a relação de afetividade com eles.

Eu gostava de uma aula que tinha apostila, coisa de laboratório. Tinha que prencher só que era um pouco difícil. Isso foi na Essência. Gostava da Educação Física! Tinha computação, era joguinho de computador... Tinha uma professora que fazia olimpíadas de grupinhos de basquete, futebol. A gente fazia, sabe aquele ginásio aqui no Ibirapuera... A gente tinha feira de ciências. Tinha uma fichinha, eu lia. Quando a pessoa chegava lá a gente lia e explicava. Eu falava de planetas... Na APAE, gostava de fazer peça de teatro... Era muito bom. Antes de eu começar trabalhar eu ia na festa junina que tem lá. Tinha as bandeirinhas. Quando chovia... nossa! Três salas chovia, molhava almofada, eu lembro disso!... Gostava dos professores porque assim são legais, ensinavam a gente. Lembro do Zeca! Da APAE. Era professor, fazia aquela água com papel (papel reciclado)... Ele era engraçado! Gostava. Quando a gente ia falar com ele, ele gostava muito da gente. (Marcos)

\section{A vivência em escola comum}

Os relatos a seguir descrevem a convivência de Ana, José, Paulo, Henrique dentro do espaço escolar de escolas regulares, envolvendo as relações com professores e colegas, revelando o cotidiano dessas pessoas enquanto alunos. Observamos pelos depoimentos como a deficiência chamava a atenção dos colegas ora despertando certa curiosidade infantil, ora um comportamento de hostilidade manifesta do grupo. 
Quando eu comecei ir para o colégio a partir da primeira série, sofria um pouco de preconceito com outras crianças. Às vezes eles me criticavam, falavam que eu não podia calçar sapato, chamava de pé torto. Por não ter muito equilíbrio me chamavam de pata, aquela coisa toda! (Ana)

Com as crianças o convívio também era normal mas sempre tinha a época da curiosidade. O que você tem? O que aconteceu? Eu falava: ah eu nasci assim problema de nascença! (José)

Na primeira escola que eu estudei, que foi no Colégio Washington fiz da primeira à terceira série. Lá foi muito difícil a convivência. Porque não tinha pessoas com deficiência na minha sala, nessa escola e nas outras também. As pessoas às vezes brincavam Ah! Você é surdo! Oh surdo! Isso às vezes me incomodava Porque na verdade eu sei que não sou surdo. Surdez total, eu não tenho. A minha surdez é moderada! Então isso incomodava, aquela brincadeira de criança, quando moleque. Mas houve um tempo que fui percebendo que quanto mais eu me incomodava mais as pessoas brincavam. Quanto mais eu achava ruim mais as pessoas caçoavam e faziam esse tipo de brincadeira. Então procurei não dar muita atenção levava na esportiva. Falava: é defeito de fabricação e levava assim na brincadeira. (Paulo)

Possuir uma deficiência no limiar, dificultou a identificação da necessidade especial de Henrique que sempre estudou em classe regular e enfrentou a incompreensão do professor sobre a sua baixa visão.

Essa coisa de baixa visão, visão subnormal a maioria das pessoas não sabem! Inclusive professor Tinha um que chegou a ponto de duvidar do quanto eu enxergava! Eu dizia: professora não tem como eu enxergar! Ah você enxerga sim, porque tem uma pessoa que tem o mesmo tipo de problema que você! Eu dizia: claro que não, cada caso é um caso! Meu caso parece que estou enxergando, mas não estou. Ai ela escrevia e perguntava: o que está escrito aqui? Eu não sei! O professor duvidava. Eu tinha que ir na diretoria conversar com a diretora, provar, pedir que conversasse com aqueles professores, eles estavam duvidando. (Henrique) 
Por outro lado no caso de Henrique muitos anos depois, partiu da escola o apoio e o encaminhamento adequado, sendo a atuação do professor decisiva para o diagnóstico diferencial da sua deficiência.

O único suporte diferente que eu tive na escola foi quando nós morávamos em Diadema. A professora vendo essa dificuldade e também o meu esforço de querer aprender me chamou. Era professora na USP. Ela falou: eu conheço umas pessoas da Escola Paulista de Medicina, que também estão desenvolvendo um trabalho lá na USP. Me passou o endereço e disse: você liga marca a consulta e, se precisar pagar você fala para mim que eu pago. Teve todo esse interesse! (Não precisou pagar). Tinha 18, 19 anos, estava no ensino médio, estudava de noite! Era uma escola estadual de Diadema mas já não lembro o nome! A professora fez a diferença, porque eu estava perdido! A minha família não tinha orientação. (Henrique)

As pessoas entrevistadas que freqüentaram o ensino fundamental em escola especial, com exceção de Marcos, a partir do ensino médio foram incluídas no ensino regular, dando continuidade à sua formação acadêmica em cursos técnicos ou ensino superior. A mudança foi significativa como demonstram suas falas.

Ele continuou com uma menina surda e três rapazes. Eles eram da DERDIC e foram com ele para o Colégio Radial. A inclusão ele achou bem dificil. Porque na DERDIC eram só 10 alunos em cada sala. Na sala de ouvinte eram 50 alunos e ele não estava acostumado com tudo isso. Os professores eram legais, principalmente o professor de matemática era muito legal. Ele não tinha intérprete na época mas o professor explicava na lousa, olha para isso olha pra aquilo e ele acabava entendendo. (intérprete de Alex)

Nem todos os colegas surdos incluídos na escola regular tiveram a facilidade de Alex que surpreendeu os professores pelo seu desempenho.

Mas tinham três surdos na sala dele que não entendiam, não conseguiam entender a matemática. Na sala dele tinha 50 alunos e numa outra sala mais outros 50. Então dava um total de 100 alunos na sala A e na sala B. A primeira vez que fizeram a prova ele 
tirou a melhor nota de 100 alunos. Só tiveram 2 pessoas que tiraram notas boas e uma dessas pessoas foi ele. Ele foi parabenizado falaram que era uma pessoa muito importante. Ele levou um susto quando ficou sabendo. Mostrou que era capaz e inteligente. Ele lembra bem desse sucesso na vida dele. (intérprete de Alex)

As pessoas como Márcia e Henrique que possuem deficiência visual relatam experiências de convívio na escola regular, indicando a condição de dependência da colaboração dos colegas para acompanhar o aprendizado pois a escola não oferecia nenhum tipo de apoio.

Na escola foi sempre assim. Eu pegava a matéria na sexta feira, fazia amizade com uma pessoa por lá, rapaz ou moça de confiança, aí passava a matéria de segunda a sexta no final da semana. Porque nem todo mundo tem a disponibilidade e o desejo de ajudar. A ajuda que eu precisava era o ditado, porque passavam na lousa e não dava pra enxergar. Tinha telelupa eu é que não conhecia. Aí o que eu fazia: oh dá pra você ditar pra mim e tal. Aí a pessoa saia de fininho, ajudava um pouquinho. Quando eu ia pedir de novo a pessoa já tinha se levantado! Ai eu percebi, puxa vida o que vou ter que fazer? Tenho que fazer amizade com uma pessoa que também gosta de estudar tem interesse de aprender, para que eu possa na sexta feira pegar o caderno emprestado de todas as matérias, no final de semana passar tudo a limpo e no domingo ainda devolver para a pessoa. Então minha vida até terminar o ensino médio foi isso. Então tinha que fazer essa peneira: uma pessoa que tinha uma letra bonita, interesse em estudar, todo esse detalhe aí. Então todo começo de ano era essa luta! (Henrique)

Se eu via que naquela semana eu não tinha pedido nada para o colega do lado eu falava: oh! fulano quer me ditar um pouquinho? Você tem que pensar em tudo isso! Às vezes ele não queria ditar o que estava escrevendo, porque eu acho que deve ser ruim. Quem tem que ditar é o professor. Falar o que está escrevendo. (Márcia)

Alex sentiu muita diferença com a regulamentação da Língua Brasileira de Sinais quando o recurso passa a ser oferecido pela escola e atualmente sente o benefício na faculdade, facilitando o acesso à educação para muitos alunos surdos. 
Na época dele o Colégio Radial não tinha intérprete de LIBRAS porque não existia a lei. Hoje já tem. Atualmente tem 60 surdos e tem vários intérpretes, mas na época dele não tinha. Agora ele está fazendo faculdade de Educação Física. Está no $7^{\circ}$ semestre e estuda na UNISANTANA. Lá tem mais ou menos 30 surdos e 25 intérpretes. É bom porque a UNISANTANA se preocupa em ter intérpretes para os surdos. (intérprete de Alex)

No curso superior, um aspecto marcante para Márcia foi a difícil convivência com os colegas expressando claramente em seu relatos, experiências de intolerância e rejeição vividas no ambiente universitário.

Com os colegas da faculdade tive muitos problemas, acho que os piores de convivência de solidariedade. Pela relação idade e mentalidade, eu acho que as pessoas teriam que ter mais noção da vida ou conhecer as coisas e você percebe que as pessoas são mais, digamos assim egoístas. Chegou um ponto que eu levei a reglete, porque eu escrevia com ela. É um equipamento manual, tem a grade e a punção para furar. Eu tinha máquina de escrever em Braille que é mais barulhenta, só que eu achava que para não prejudicar a minha turma eu não ia levar aquela máquina que fizesse muito barulho para não atrapalhar, apesar de ser mais rápido pra mim porque a velocidade de escrita da máquina é bem maior que da reglete. Então eu escrevia na reglete. Um dia uma menina fez um comentário infeliz na turma, o professor de Inglês estava fazendo ditado oral, inglês técnico, todo mundo escrevendo e eu também. Ela falou assim: ah! fica esse barulhinho tec-tec- tec na nossa cabeça. Achei tão infeliz da parte dela e o professor ainda riu. Então eu senti pior ainda porque se o professor não tivesse opinado, tudo bem. Mas pelo menos que não tivesse dado risada. (Márcia)

Nesse relato pudemos constatar a conivência da postura do professor com a aluna e em outros percebemos um comportamento que variou entre uma atitude de compreensão e apoio a um descaso e desrespeito.

O convívio era normal, jogava bola, fazia educação física participava, o professor falava o que você não puder fazer você não faz. (José) 
Tinha um professor de fisica e que não conseguia passar pra gente os gráficos, e aí os alunos também não tinham como passar porque a gente continuava com a situação dos cadernos emprestados ou do professor que ditasse ou do aluno que ditasse. Então a gente não aprendeu nada de física, nem no segundo, nem no terceiro ano. Só teoria.(Márcia)

Uma vez um professor falou assim para nós duas, eu e minha amiga que estudávamos na mesma turma. Porque vocês não ficam em casa? Vocês deviam aprender cozinhar e ficar em casa. Porque vocês estudam? Então ele falou isso! Achei o comentário infeliz! Eu falei para ele: ah professor, sabe o que eu acho? Acho que não preciso aprender nada disso porque eu quero aprender música, na época eu queria. E ficou por isso mesmo no ensino médio e eu lembro que tinha 17 anos. (Márcia)

O aluno que possui cegueira como é o caso de Márcia enfrenta o despreparo da falta de recursos da escola regular gerando um relacionamento conflituoso com os professores despreparados.

Então assim os professores são piores que os alunos na verdade! Tinha um que falou assim: eu não estudei para ser professor de deficiente! Eu não fiz faculdade para isso. Eu falei: então você vai ter que se virar porque eu não estou aqui para ter aula com professor que enxerga. Tinha uma amiga que falava mais! Ela era a nossa porta voz, ela era mais velha, tinha 21 anos e já tinha enxergado. Eu era novinha tudo eu chorava. Mas depois eu parei de chorar na frente dela. Então aprendi que não adianta abaixar a cabeça. A professora reclamou: ah eu não sei falar, escrever, tudo ao mesmo tempo! Então a senhora vai ter que aprender porque a senhora vai ter que falar. Senão como que eu vou copiar. Mesmo assim tem professores que não admitem e não falam! Então você fica na sala sentada, esperando a boa vontade de seu colega, que um dia está a fim de te ditar, outro dia não está! Eu precisava de ditado. O professor ficava escrevendo na lousa em silêncio. E ele não falava, eles davam os cadernos e isso na faculdade também. (Márcia) 


\subsubsection{O lugar da família}

Os dados referentes à família indicam um apoio significativo dos pais e de irmãos, desde o início da identificação da deficiência envolvendo a busca de tratamentos especializados, a estimulação e o convívio familiar. Todavia observamos que evidenciaram também situações conflitantes.

A deficiência motivou uma atitude de enfrentamento na maior parte dos membros das famílias das pessoas entrevistadas sendo a figura da mãe uma presença marcante nesse processo; os depoimentos também falam da falta de recursos econômicos e de profissionais especialistas enfrentados por algumas famílias.

Com uns 3 anos mais ou menos ela me levou ao médico. Porque o pessoal falava que precisava fazer cirurgia para corrigir! Aí eu fui pra Ilhéus, lá na cidade onde eu morava não tinha recursos. Então a gente tinha que ir para Itabuna ou Ilhéus, onde a medicina era mais avançada. Com 1 mês o médico já colocou o gesso. Mas o gesso não resolvia. Tinha que fazer cirurgia Aí o meu tio que era vereador falou: vocês vão pra Itabuna que lá é melhor. Ai a gente foi pra Itabuna... Viemos também pra São Paulo, porque ela trabalhou com uma família lá, e o pessoal mudou para cá. Ficou todo mundo lá, meus irmãos, meu pai. (Ana)

Dai eu fui ao médico. Mas eles também tinham essa dificuldade, o oftalmologista do interior não sabia, só fui saber da toxoplasmose aqui em São Paulo. Eu cheguei a usar óculos literalmente fundo de garrafa mesmo! E não resolvia!... Mas falavam que tinha que usar, colocava mais grau e nada resolvia. Só quando mudei para São Paulo é que o problema foi identificado entre 18 a 19 anos. (Henrique)

A procura de tratamentos e recursos educacionais evidenciam o esforço da família na luta para enfrentar a deficiência. Os pais de Márcia não hesitaram em mudar de país, para oferecer o melhor atendimento especializado para ela, e a família de José também buscou tratamentos em outros locais.

Quem acompanhava nos tratamentos eram minha mãe e minha avó. Meu pai trabalhava não tinha tempo para isso... Lembro que eu passei por uma cirurgia, foi 
uma cirurgia meio longa, demorada, fiquei engessado, tinha que fazer fisioterapia. Tinha uns 7 a 10 anos. A cirurgia foi feita em Marilia, na Santa Casa que tinha um médico ortopedista muito conhecido. (José)

Um aspecto fundamental levantado por algumas pessoas entrevistadas, refere a atitude da família quanto à aceitação da deficiência. Alguns relatos colocam essa vivência como um fato marcante de sua vida, outros revelam conflitos familiares.

Entre as passagens mais importantes acho que foi a sociabilização que sempre tive, pois minha mãe nunca me proibiu de nada, sempre brinquei muito na rua. Mesmo na adolescência, minha mãe nunca falou ah vai ficar só com pessoas que não enxergam ou, vai ficar só com pessoas que enxergam! Porque a minha família, na verdade ela só contribuiu em relação a minha deficiência! Eles foram sempre muito tranqüilos, nesse sentido. Porque eles foram muito normais, entendeu? (Márcia)

Tinha vez que eu ia nos médicos minha mãe sofria um pouco de preconceito com as outras mães que viam, achavam absurdo aquilo. Mas eu tive muita sorte porque ela não foi uma mãe de, ah! eu tenho vergonha da minha filha! Ela tinha prazer de expor, de acolher, tipo por na escola comum não uma escola especial! Para ela era um orgulho!Eu fui crescendo e ela foi me ensinando, se alguém chegar... não leva em conta. Entregue nas mãos de Deus ele sabe o que faz! (Ana)

O meu nível de comunicação, atribuo à minha mãe poder acreditar em mim. Ela foi firme para eu voltar e me colocar na sala regular. O acompanhamento dela foi sempre importante. Ela estava sempre nas reuniões, queria saber o que eu tinha a melhorar mais. Se perdia o ônibus ou atrasava, ela levava até outra cidade era a participação dela e isso foi muito importante, o apoio dela. Meu pai já não, tinha uma cabeça de preconceito. Toda essa experiência de três filhos com deficiência ele ainda acha que não tem. Fala: todo esse aparelho, não precisa disso! Minha mãe não. Sempre lutando, sempre batalhando. Não! Ele vai usar vou passar nos melhores médicos. Ai eu usava o aparelho, ela brigava batia de frente. Meu pai não tinha esse estudo, ele teve uma criação rude, na roça, às vezes acha que é pouco caso fala que eu escuto bem... Um dos 
motivos que eu estava procurando emprego foi isso de estar mostrando paro meu pai que eu tenho capacidade, provar isso a ele. (Paulo)

Ainda que muitos recursos tenham sido oferecidos pela escola especial, as famílias exerceram um papel de significativo apoio para o seu desenvolvimento, destacando-se o papel dos irmãos nos depoimentos de pessoas com surdez ou cegueira.

Com a falta de comunicação com a família ele começou a desenvolver mais a comunicação com o irmão. Eles usavam sinais domésticos. Ele e o irmão acabaram criando sinais domésticos e foi só na DERDIC que ele aprendeu a LIBRAS. Naquela época o irmão aprendeu também. Aprendeu com ele. E o irmão começou a ajudar. Quando o irmão foi na DERDIC ele melhorou mais ainda. O irmão ajudava muito, como por exemplo o jornal, televisão, política, todas as coisas que passavam na TV o irmão passava. As coisas do futebol passava todo o tipo de informação, com se fosse um intérprete para ele. Dava conselho quando tinha dúvida e quando ele chegava na escola tudo que o irmão passava pra ele, ele passava para os outros surdos. Porque as vezes os outros surdos não tinham uma pessoa na família para tentar falar. Aí o Alex tentava ajuda. (intérprete de Alex)

Um fato marcante foi a ajuda da minha irmã, da minha mãe no ditado das matérias, para que eu acompanhasse o ensino médio e o curso superior. Elas tinham que ditar para que eu pudesse escrever, elas aprenderam o Braile para me ajudar! Desde o ensino fundamental. Minha irmã lia em Braile, minha mãe era voluntária no colégio que eu estudava e ela também transcrevia os livros. Só que minha mãe tinha mais dificuldade de ler, ela conseguia escrever. Minha irmã era aquela de olhar a lição se não estava certo, rasgava que nem faz com os que enxergam! (Márcia)

O papel dos irmãos mais velhos ganha importância também nos relatos de convívio caracterizando a proteção.

Até os 4 anos eu nem ligava muito (para a deficiência). Quem ligava eram os meus irmãos! Se eu estivesse com eles e alguma criança mexesse comigo, aquilo ali era o fim! Eu não sabia me defender na verdade. Então eles me defendiam. (Ana) 
Meu irmão mais velho nasceu normal não tinha deficiência. Só que ele gostava de brincar. Ah você não escuta moleque! Falava: você é surdo, fazia brincadeira que me incomodava. Agora ele está com 30 anos. Faz 1 ano ele está perdendo a audição. Às vezes eu brinco com ele. Isso toca ele como me tocava na época também. Foi marcante pra mim! Porque eu era muito apegado com ele. São dois anos de diferença! Mas apesar disso ele me defendia. Se alguém falava você é surdo, você com esse cabelo grande aí... Meu irmão me defendia! (Paulo)

\subsubsection{Inclusão no trabalho}

A pesquisa levantou o processo de ingresso no mercado de trabalho, a idade e as primeiras experiências e como obtiveram as oportunidades.

Trabalhei na área de atendimento ao cliente e ajudava na seleção, fazendo a triagem dos candidatos na recepção. Foi o meu primeiro trabalho registrado e anteriormente eu trabalhei durante 8 anos com a minha irmã, no colégio com atendimento também. Só que era autônomo. Ela tinha um trailer, onde servia almoço, bebidas, lanche, daí eu trabalhava com ela. (Ana)

Comecei com a primeira experiência em empresa telemarketing, com 18 anos. Eu trabalhava das 6,30h às 9,30h mas não era registrada. Recebia uma ajuda de custo e mais as comissões das vendas que eu fizesse. Eu entrei lá porque tinha um amigo deficiente lá. Era um deficiente visual Depois que passou um tempo nos transferiram para a parte do dia e nos registraram. Naquela empresa tinha cinco deficientes: eu a minha amiga mais uma pessoa, e um casal que é esse amigo nosso e a namorada dele. Todos tinham deficiência visual. (Márcia)

Eu comecei a trabalhar fazendo um estágio na Procuradoria Geral do Estado em Suzano. Eu já estava no segundo ano da faculdade. Consegui por meio de um amigo, na verdade amigo da minha prima que já trabalhava nessa área, era advogada. Fiquei quase dois anos. No $4^{\circ}$ ano fui fazer outro estágio que já era remunerado. Esse estágio consegui através do amigo do meu pai que era advogado. (Paulo) 
Comecei a trabalhar com 18 anos e a primeira oportunidade foi na corretora de seguros. Meu tio era da área financeira e conseguiu pra mim. (José)

Meu primeiro emprego foi na época da escola que tinha a professora que me ajudou. Lembrei o nome da escola era Filinto Muller, uma escola estadual em Diadema! Um colega Adilson me deu a indicação do trabalho. Foi de ajudante geral para trabalhar em uma indústria metalúrgica. Tinha uns 19 anos. Ia procurar nas empresas, nas lojas, mas eles não queriam me aceitar! Por causa da deficiência. Trabalhei como ajudante geral, tirando cópias em uma máquina especial chamava epiográfica. Comecei no departamento de desenhistas mecânicos. (Henrique)

O CPT da APAE encaminhou ele para a empresa! Era tudo novo na época e ele se adaptou muito bem Agora ele é funcionário da empresa. Foi efetivado, não é mais terceirizado. A função é office boy interno ligado às secretárias de uma área. Antes era geral. Foi o primeiro e o único trabalho dele. Espero que fique! Se Deus quiser! (pais de Marcos)

Ele começou como estagiário (em empresa estatal de energia) trabalhou lá dois anos. Depois que foi registrado na carteira (efetivado) ficou dois meses e saiu porque o governo cortou 2000 funcionários e ele saiu. (intérprete de Alex)

Com exceção de Marcos, os caminhos para ingressar no mercado de trabalho ou buscar uma recolocação seguiram o mesmo percurso de outras pessoas que não tem deficiência: pesquisar os sites de empresas, entregar currículo, aguardar entrevista, contatar amigos. Com a divulgação da lei de cotas e sua fiscalização, foram descobrindo uma alternativa e passam a se cadastrar em bancos de dados específicos de instituições, ou empresas de consultoria especializadas na colocação de pessoas com deficiência.

Toda semana saía pra entregar currículo. Nunca tinha oportunidade, já havia entregado bastante! Foi quando falei: ah, desisto não vou mais procurar. Todo lugar que eu vou nunca tem. Aí comecei assistir o jornal na televisão falando sobre a lei da cota essa coisa toda! Aí eu falei assim: então uma hora vai surgir, porque eles são obrigados a ter uma pessoa portadora (de deficiência) no mercado, então uma hora vai 
chegar a minha vez. Foi quando me chamaram, para trabalhar com atendimento ao cliente. (Ana)

Eu chegava todo dia em casa mandava currículo. E toda noite ficava até de madrugada mandando. Pegava o site das maiores empresas e mandava o currículo. Eu mandei mais de 100 mandei bastante. Eu levava também em São José dos Campos, lá perto, pessoalmente, em Guarulhos também! Daí eu já estava meio desanimado. Um dia eu mandei para agência da GELRE e ligaram pra mim no outro dia. Falaram que tinha uma dinâmica em São Paulo, perguntaram se eu queria ir. Fui aprovado deu tudo certo. (Paulo)

O fato de informar previamente que tinham uma deficiência trouxe dúvidas para alguns dos entrevistados, pois esse dado poderia representar uma barreira. Só quando perceberam a vigência da lei de cotas reservando vagas nas empresas para pessoas com deficiência, os sujeitos relatam que passaram a informar sobre a sua condição.

Jornal, anúncio comum, nunca deu certo porque eles tinham o susto da descoberta da deficiência. Você chegava pra participar de alguma entrevista você via a surpresa da pessoa. Então não dava muito certo. Na verdade eu nunca omiti (a minha deficiência) só que quando você cadastra em alguns sites (das empresas) você não tem uma opção de colocar que você é deficiente e então você não coloca. Hoje em dia até tem, mas naquela época não. (Márcia)

Quando eu vendi a minha loja, eu tinha contato com o Centro de Solidariedade. Lá tem uma pessoa que atende exclusivamente pessoas com deficiência. Então eu tinha contato e apareceram duas empresas oferecendo vagas reservadas. Eu passei pelos dois processos seletivos. Foi a primeira vez que tinha passado a informação da deficiência. Porque eu fiquei sabendo mais desse negócio de cotas. Achei que ia fazer uma diferença a favor se colocasse no currículo. Poderia abrir mais algumas portas. (José)

Eu mandava currículo específico. Na maioria dos sites das empresas aparece lá. Agora está tendo muito, pedem para você colocar portador de deficiência e identificar sua 
deficiência. Dai eu anexava o currículo com um destaque que era portador de deficiência, para a empresa saber e me colocar na vaga destinada. (Paulo)

Quando eu saí dessa indústria de plástico fui para um órgão de trânsito. Foi em 2003 para uma cota. O processo seletivo foi através de uma instituição que cuida só de pessoas com deficiência, qualquer deficiência. Fui com prestador de serviço pela AVAPE na função de auxiliar de escritório. Então o critério era ter a deficiência pela lei e você precisava saber escrever, preencher dados, informática básica, para passar os documentos de multa, para o processamento de dados. Era tranqüilo! Agora na empresa atual fui pela Gelre passei por entrevista para vaga de deficiência. (Henrique)

Na empresa atual fui escolhido para participar da seleção porque tinha a deficiência. Agora isso é legal, está mais tranqüilo porque é um direito! A minha deficiência não é a mais grave, mas é uma deficiência não é? Então isso dai em outro serviço poderia me atrapalhar, então tenho que aproveitar! (Paulo)

Emprego mesmo sozinha digamos, sem ajuda de órgão especialista ou por indicação, eu não ia conseguir. Mas eu sempre trabalhei, mas ir pelo anúncio de jornal para conseguir uma vaga isso nunca consegui. Eu tentei, mas é difícil. (Márcia)

Algumas vezes a falta de informação, ou o próprio preconceito retardou a declaração da deficiência e conseqüentemente a possibilidade de usufruir de um direito garantido pela legislação, como observamos pelos depoimentos que seguem:

Na verdade eu tomei ciência disso há pouco tempo atrás. Não tinha conhecimento dessa lei de cotas. Eu conhecia muito por cima. Eu nunca me apoiei nisso para tentar conseguir emprego. Aliás eu nunca coloquei no meu currículo que era portador de deficiência. Eu devia ter colocado. Eu acho que não sei nunca pensei sobre isso... Não colocava porque acho que era preconceito de mim mesmo pela preocupação com o preconceito da empresa acho que é isso. Nessa empresa atual foi a primeira vez, ela tem um programa de contratação de deficientes. (José) 
Só este último foi pela Gelre para vaga reservada, pela primeira vez usei a cota Acabei percebendo uma coisa que eu talvez tinha um certo preconceito contra a minha deficiência. Me incluindo ainda com certo preconceito na minha cabeça. Porque às vezes a gente tem um auto preconceito e isso acaba dificultando. Daí você tem que se aceitar do jeito que você é, com defeito e com qualidades, porque todo mundo tem defeito. Acho que isso está mais tranqüilo agora. (Paulo)

\section{Medidas de acessibilidade}

Os sujeitos entrevistados também foram solicitados a comentar sobre as medidas de adaptação adotadas pela empresa para adequar o ambiente físico de trabalho ás suas necessidades.

Mesmo que a natureza e a intensidade de sua deficiência nem sempre exigisse adaptações no ambiente de trabalho, as pessoas entrevistadas indicaram uma atenção do empregador com essa questão e emitiram opiniões críticas.

Pelo que eu vejo é pouco mas já é alguma coisa. Por exemplo o mobiliário. No meu departamento tinha uma estagiária com deficiência, era no braço. Ela tinha uma cadeira especial, foi feita uma adaptação. Até hoje o nosso prédio não tem outras adaptações. Mas tem uma plataforma para cadeirantes ao lado da escada na entrada. Só não contratou ainda nenhum. A empresa vende produtos nessa área. Houve depois comentários sobre a minha deficiência. Era para ver se podia descer escadas, carregar peso. Acho que era para ver se tinha algum problema se eu ia conseguir me locomover pela empresa, se ia trazer alguma limitação, acho que era isso. (José)

Mas em termos de acessibilidade as empresas ainda fazem muito pouco, são poucas empresas que tem rampa de acesso $E$ isso mostraria o interesse dela pelo público consumidor. $O$ deficiente também é um público. A rampa serve de acesso ao cadeirante e ao funcionário também! (Paulo)

Quando a deficiência requer medidas concretas e específicas para adaptar o posto de trabalho, como ocorreu com Márcia, que necessita de um software audível para cegos, verificamos que algumas empresas já oferecem o recurso, outras encontram dificuldades. 
Nesses casos, pelo seu depoimento Márcia deixa claro que a contribuição da pessoa cega é fundamental para adoção de medidas eficazes. Ressalta também que enfrentou resistência e descrédito na sua capacidade profissional, pela falta de informação sobre os recursos existentes para pessoas com deficiência realizarem suas atividades de trabalho.

Fui trabalhar em uma empresa de Pager que passava mensagem e eles adaptaram uma baia, uma sala com baias para 12 deficientes. Lá foi tudo a empresa que fez, já tinha um projeto uma cota. Contrataram uma empresa do Rio de Janeiro que adaptou o sistema. Só que quando você chegava lá o que eles fizeram não foi o suficiente. Você acaba também participando dessa adaptação. Porque quando você começa a ver o sistema funcionando você começa a identificar falhas. Lá tinha uma estrutura toda montada inclusive um esquema de ambientação, apostila em Braille, foi tudo pensado, sempre tinham essa preocupação. Na verdade, foi a empresa mais fácil, em que a gente teve menos trabalho apesar de a gente precisar de algumas adaptações foram poucas. (Márcia)

Na empresa atual também teve uma adaptação. Compraram o sistema que é o Virtual Vision, que é um sistema comercial fabricado aqui no Brasil, por uma empresa que é a Micropower. Eles compraram esse sistema porque eu indiquei. (Márcia)

No começo não queriam me colocar no Pabx, me colocaram no outro local me deixaram lá. Na verdade não era que não queriam me colocar na recepção, é que achavam que eu não conseguiria manusear o Pabx. Aí eu falei não! Se for esse o caso então vamos fazer um teste, eu fico e se não der certo aí me coloca em outra atividade. Eu até eu mandei trazer de Curitiba umas canetas que acendem, elas apitam. Essa caneta vinha como uma solução. Só que quando chegou aqui como as luzes do Pabx eram muito pequenas, você não conseguia saber qual o local para você colocar a caneta entendeu. Eu sabia que ia apitar mas eu não sabia onde estava o local e com isso aí não deu certo Aí eu comecei a atender mesmo assim. Eu falei que não ia atrapalhar a empresa, eles iam me deixar uns 10 dias. Eu comecei aprender consegui identificar a ordem, memorizar o Pabx com o atendimento automático e o fone de ouvido... Mas eu é que tive que tomar essa iniciativa porque se não eles teriam me encostado lá no outro canto e não iam fazer nada! (Márcia) 
O tema acessibilidade do computador para pessoas cegas ainda traz muitas discussões e nem sempre as medidas a serem implantadas são simples, como Márcia reforçou em seu depoimento.

Não, não! O assunto é complicado, sempre tem alguma coisa nova e se tem alguma coisa que não funciona você tem que ter o vidente, aquele que enxerga. A colaboração do colega vidente é importantíssima! A gente não fica na empresa se não houver!

Alex considerou que necessita de um apoio de comunicação para conseguir trabalhar, reivindicando um intérprete de LIBRAS, obtendo pela primeira vez esse recurso onde trabalha atualmente.

Em nenhum local de trabalho teve intérprete. Só agora ele tem uma. Mas depois de muita luta árdua. Vai fazer um ano em dezembro que entrou lá, como cargo de confiança, comissionado. (intérprete de Alex)

\section{Relacionamento no ambiente de trabalho}

Incluir-se no mercado de trabalho significa também participar de um grupo, das relações sociais e as pessoas entrevistadas relataram essa convivência. Os depoimentos revelam a percepção que os sujeitos da pesquisa tiveram sobre o meio social, em alguns casos já informados e sensibilizados.

A convivência foi normal porque às vezes até esqueciam. Assim a deficiência é visível mas também não é. Porque às vezes, até em casa, eu vou por exemplo na lojas com a minha irmã, ela fala: nossa que sapato lindo porque não compra pra você? E eu não calço sapato! Na empresa a mesma coisa. Ah, não vou falar porque ela é deficiente. Não! As pessoas já vêem normal, conversam de tudo. Às vezes fazia muito frio, estava chovendo e as pessoas me perguntavam: nossa você não sente frio nos pés?Não te incomoda a chuva? Mas não era com preconceito era tipo cuidado entendeu? (Ana)

Sempre que eu chegava num ambiente novo de trabalho eu procurava deixar claro para as pessoas a deficiência auditiva. Eu faço a leitura labial, mas eu escuto! É para não 
perder nada que as pessoas estão falando. As pessoas cooperavam, a maioria sim (risos) mas tinha gente que não! Achava até que a atenção deles era boa, acabava sendo uma coisa natural. E eu também ia me adaptando às pessoas. (Paulo)

Era muito tranqüilo não tive problemas, salvo com algumas pessoas que às vezes você passava uma informação e por você ser deficiente não havia credibilidade no que você falava. Salvo isso nas empresas eu não tive nenhum problema. Teve uma exceção. Eu tinha que anotar os telefones porque os operadores tinham que retornar a ligação. E as vezes as pessoas te passavam o telefone errado, ou você podia ter anotado errado. Mas isso não quer dizer que você é deficiente ou não. Todo mundo tem erro, se você é muito nova sem experiência, você acaba mesmo fazendo alguma coisa errada. Tinham algumas pessoas ali que atribuíam à deficiência. Achavam que se fosse outra pessoa ali anotando, não ia ter problema com isso. Então a gente tinha esse problema da pessoa te subestimar, achando que você é menos capaz. (Márcia)

Eu me sinto muito bem. Tranqüilo, nunca passei por nenhuma situação difícil aliás em nenhuma empresa. Sempre foi um bom relacionamento. Trabalhava com cliente interno, externo... (José)

Para mim está sendo algo novo e gratificante, porque era o que eu sempre busquei. Uma empresa melhor, mas que me respeitasse enquanto deficiente, enquanto cidadão, enquanto pessoa e isso eu encontro lá. Literalmente mesmo, eles respeitam, tem paciência, buscam ser solidários, ajudar, saber se estou assimilando o aprendizado ou não. Tem toda essa gama de preocupação da parte da empresa. O mínimo que eu posso fazer é ser recíproco com esta empresa que está apostando em mim. (Henrique)

Na outra empresa que eu trabalhei eu não era funcionário, eu prestava serviços lá. Então ali num órgão público talvez por falta de conhecimento, por falta de informação ou por ser simplesmente um órgão público as pessoas não estão nem aí. Então as pessoas olhavam torto pra mim. Era quase que diária essa falta de respeito. Era com o deficiente e de uma forma geral também! (Henrique) 
Dentro da empresa tem que respeitar um e outro. E se a pessoa falar alguma coisa para mim, falo com meu chefe ai ele vai falar com ela. O pessoal é muito legal lá. (Marcos)

A grande diferença na empresa é que o pessoal trata de forma comum, como um funcionário. Adoram ele! Apesar de todo o problema de comunicação ele fala com todo mundo! A gente até dá umas puxadas nele porque com qualquer pessoa ele conversa! Esse é o perigo, porque as pessoas estranham. Mas no trabalho todos conhecem então dá pra confiar. (pais de Marcos)

No começo foi um susto para as pessoas! Porque eles se depararam com 20 pessoas cegas fazendo uma vivência de 20 dias, cada um espalhado em um departamento. Era aquele monte de cego no café de manhã. Na verdade no departamento não teve problema. Eu encontrei a minha chefe que foi a pessoa responsável por eu ficar na empresa, depois da experiência... Com ela sempre foi muito bom o relacionamento. Porque aí ela já começou a me ensinar o Excel e depois formatar textos. Como eu tinha problema com a escrita, o deficiente visual tem problema com ortografia, porque a gente não se habitua a ler muito, porque os livros impressos são muito grandes. Com o micro era mais tranqüilo e eu tinha o corretor ortográfico... Mesmo assim ela olhava e conferia. Era bom porque conforme ela ia conferindo eu ia aprendendo. Ela indicava além de um erro de ortografia tinha um ponto e vírgula, ela era mais que professora. Era a pessoa que estava disposta entendeu? A pessoa que está disposta é diferente. (Márcia)

A preparação do ambiente da empresa orientando e sensibilizando as pessoas para a convivência com a diversidade, pode representar um elemento de facilitação na integração das pessoas com deficiência, conforme a opinião de Márcia. E no caso de Marcos, as chefias preparadas orientaram o seu trabalho, pois o programa foi supervisionado pela instituição que o encaminhou.

Eles falaram que estavam contratando 12 pessoas deficientes, as pessoas foram orientadas. Você chegava ai eles falaram: ah, a gente foi informado que vocês iam chegar e o que a gente pode fazer para ajudar vocês? E ficava todo mundo em cima e 
queriam levar e queriam trazer. O ambiente foi sensibilizado antes. Quando a gente chegou para trabalhar as pessoas queriam saber, foi mais tranqüilo. (Márcia)

Iam duas moças da APAE Elas iam conversar, eram supervisoras, iam para ajudar na integração dele. Orientavam. É uma integração importante porque as pessoas não sabem como tratar e tem que chegar, explicar. Faziam o elo com a APAE. A sorte que ele não é tímido. Porque se fosse ele não ia fazer muita coisa. A APAE deu um apoio. A Gelre também deu orientação porque ele estava atrasando. (pais de Marcos)

Mesmo assim, a convivência no ambiente sendo ele previamente orientado ou não, gerou dificuldades para pessoas como Márcia, Alex, e Marcos. Algumas vezes a reação de superproteção, de desvalorização, ou até mesmo de deslealdade, estiveram presentes conforme seus depoimentos.

Uma vez a impressora estava acabando a tinta e a cor do relatório mudou, ficou rosa não sei, e ninguém falou. Eu achava que tinha esse apoio, mas as pessoas falavam que estava certo só para não ter o trabalho de te ajudar! Então é difícil. (Márcia)

Então as pessoas às vezes ficavam meio afastadas, outras olhavam meio pelo canto: você viu eles? Isso dentro da empresa. Tinha uma máquina de refrigerantes, salgadinhos, café e as pessoas vinham ajudar. Às vezes tinha gente que ficava olhando... Eles perguntaram: vocês querem adaptar as máquinas, a gente põe em braille e faz não sei o que. Falamos: não! Nós vamos adaptar as pessoas. Então é um trabalho assim. Um dia vinha um, vinha outro e fomos percebendo que não precisava mais pedir. Era chegar perto da máquina aí chegava alguém. Acabou que as pessoas foram se habituando. Fomos tirando o medo das pessoas, elas foram trabalhando o preconceito. (Márcia)

Depende, tem pessoas ouvintes que não tem coragem e saem, pessoas que fogem mas ele vai atrás, explica que ele consegue se comunicar. Pede para falar palavras fáceis, mais devagar. As pessoas ficam um pouquinho melhor. Por exemplo, tem que falar o horário de reunião ele fala, mas ele não tem condições de explicar o que aconteceu é 
uma barreira. Agora tem intérprete, faz 2 meses. Quando ele percebe que a pessoa entende ele não chama a intérprete. (intérprete de Alex)

Quando era novo na empresa, o pessoal não sabia como lidar com ele. Tanto que tem as máquinas de café eles tinham medo. Ele falava pode deixar que eu me sirvo sozinho! Ele pensavam que ele nem sabia mexer em um copinho de café. Eles não sabem que ele sabe. Se a pessoa tem problema fisico, ou visual é fácil. É mais simples porque está se vendo! Agora quando é um problema intelectual é complicado, as pessoas não sabem como ajudar, até onde! Queriam servir o café pra ele, ele disse não pode deixar que eu me sirvo! (pais de Marcos)

Os depoimentos deixam claro a postura pro ativa das pessoas com deficiência que foram ajudando o ambiente a conviver com as diferenças, com segurança e determinação.

Na verdade tudo que é novo gera medo nas pessoas. Quando você entra na empresa é novo pra você mas também é novo para as pessoas. Então você tem que ter essa noção. Você não pode ser uma pessoa muito magoada entendeu? Você tem que levar a situação com a maior frieza. Se você não tiver, você não fica em lugar nenhum. (Márcia)

A fala dos pais de Marcos resume o estímulo à novas aprendizagens que o convívio com o diferente pode trazer.

A empresa também aprende. Quem falava isso era o gerente. Ele falava a gente está aprendendo muito com ele. (pais de Marcos)

\section{O crescimento profissional}

A meta de crescimento profissional vem sendo perseguida com muito empenho pelas pessoas entrevistadas que revelaram uma crença em seu potencial de desenvolvimento.

A evolução na carreira depende da busca de novas oportunidades e de continuidade da qualificação profissional, desafios que as pessoas entrevistadas demonstraram que vem enfrentando. Ana trabalhou com dupla jornada, buscou outras oportunidades solicitando seu 
desligamento. Alex e outros enfrentaram o desemprego, esforçando-se para se manter incluídos no mercado.

No periodo que eu estava trabalhando na primeira empresa também trabalhava com a minha irmã. Eu vivia na casa dela não tinha despesa nenhuma. Todo o dinheiro que eu ganhava com ela eu guardava. Hoje eu pretendo fazer uma faculdade. Eu sempre pensei em fazer, mesmo quando eu terminei o segundo grau. Mesmo tendo a cota o mercado continua sendo competitivo então a gente tem que estar qualificado para isso. Eu penso em fazer carreira na empresa adquirir novos conhecimentos.(Ana)

Depois ele entrou em uma empresa de informática trabalhando como programador Trabalhou 5 anos e depois foi mandado embora porque a empresa teve uma fusão, era programador de WEB também. (intérprete de Alex)

Falei com meu gerente que aquela vaga, havia entrado uma vaga para pessoa com deficiência na agência em que trabalhava, era interessante e ficava próxima da minha casa. Você tem seus objetivos, sonhos de crescer profissionalmente Ele ligou na nossa matriz passou informações sobre meu trabalho dizendo que eu era competente uma menina de confiança. Falaram que o único prejudicado seria ele, porque ele podia me perder (risos). Eu participei e o resultado foi dado no mesmo dia. Eu me desliguei e estou começando na nova empresa. Era assistente de atendimento e agora fui contratada como auxiliar administrativo. Meu objetivo é conquista, desafios, porque eu nunca trabalhei na área e tem coisa que eu não conheço. Eles estão pagando um treinamento. Eu acredito no meu potencial, que eu vou ter uma oportunidade de fazer carreira e crescer profissionalmente.(Ana)

Queria sair de onde estava não pelo salário mas sim pela vontade de aprender algo mais. Nunca me escorei na deficiência como já disse, não sou de ficar cruzando os braços, não gosto de me conformar com nada, aceitar é uma coisa e se conformar outra! Colegas meus que estão lá mais de 10 anos fazendo a mesma coisa! Quer dizer que a pessoa não se tocou, não vê uma luz. Ah eu quero algo mais! Eu falei preciso procurar algo mais, crescer, porque eu sei que en tenho capacidade, mas estou precisando de uma oportunidade, ser um pouco mais lapidado, eu tenho consciência do 
meu potencial. Ter condições para que eu mesmo possa investir um pouco em mim, um salário maior para poder fazer um curso mais específico, não básico, de informática, mais pra frente fazer um curso de idiomas porque eu gosto de inglês, de espanhol, gosto de alemão, fazer uma faculdade! (Henrique)

Por outro lado o desemprego não foi problema para Marcos e no caso de José também não houve dificuldade.

Entre uma e outra colocação cheguei a ficar uns 3 a 4 meses desempregado. Nada muito longo. Acho que o maior período foi esse.(José)

\section{A proteção legal: lei de cotas}

Solicitadas a opinar sobre a lei de cotas, que representa um caminho de inserção no trabalho, garantido pela legislação brasileira, as pessoas com deficiência sentiram o benefício direto de sua fiscalização nas empresas privadas.

Procurei a vaga reservada porque o próprio mercado de trabalho ainda tem muito preconceito em relação aos deficientes. E a empresa hoje para me contratar se não for pela cota seria difícil. Eu já comecei a enxergar isso. Hoje o que eles querem é quase esse exemplo que eu vou dar agora. Recém formado com experiência. Isso não existe! O mercado está exigente, é a globalização, um conjunto de coisas. Então eu não vou contra o sistema! Tenho que buscar um caminho que seja melhor pra mim e pra minha família. (Henrique)

A lei de cotas é uma oportunidade muito boa que estão oferecendo. Porque antes a gente se sentia rejeitado, não acreditavam no nosso potencial. Achavam assim: ah é uma pessoa deficiente então não tem qualidades. As pessoas vão muito pela aparência. Antes eles me achavam inválida então não te davam oportunidade para você mostrar seu potencial. Então se você tem interesse, mesmo que você não tenha experiência, mas está mostrando força de vontade então cabe a mim mostrar a minha força de trabalho.(Ana) 
Eu acho justo!Muitas empresas consideram isso como uma imposição, não é uma coisa espontânea contratar deficiente. Eu acho que é justo. Porque assim com a deficiência tem que ter algum beneficio, algum diferencial. Exemplo para comprar um carro. Tem a isenção do imposto, eu já comprei um carro assim. (José)

A lei de cotas ela veio pra nos ajudar e na minha opinião é bem vinda mas chegou tarde! Já deveria existir há muito tempo, até antes de eu vir para São Paulo. Essa lei de cotas ajuda muito, porém ainda falta lapidar essa lei, fazer com que as empresas saibam um pouco mais o que vem a ser deficiência e os níveis. Falta informação e muita por parte da empresa. Então precisa a empresa se informar mais, o próprio governo ampliar essas informações com as empresas, orientar para que não haja esse tipo de discriminação, preconceito, que ainda existe muito. (Henrique)

Mesmo com o apoio que a lei de cotas significou para a inclusão no trabalho, há um olhar crítico quanto a sua eficácia como meio de mudança da sociedade e ainda gerar a possibilidade do mercado acabar discriminando as diferentes deficiências.

Acho que a lei de cotas é uma lei assistencialista, Você vai cuidar porque tem que ajudar as pessoas com deficiência. Na verdade ela tem essa intenção de ajudar! Não de formar uma opinião, tipo mudar a opinião das pessoas sobre a deficiência. É fazer aquela lei de contratar um ou dois, fica a sensação de dever cumprido, não vai formar opinião entendeu? A opinião continua a mesma, a lei de cotas na minha opinião piorou, porque coloca dois mundos! Um dos dito normais e um dos portadores de necessidades especiais. (Márcia)

Vamos supor: tem uma vaga aí tem uma pessoa que enxerga e uma pessoa sem dedo. Então vou concorrer primeiro com uma pessoa que enxerga, depois com essa pessoa sem o dedo. Dentro da deficiência ele tem menos deficiência do que eu! Então são dois com quem eu vou concorrer! Então para o deficiente mesmo, que tem deficiência sensorial, como nós e os surdos, os cadeirantes, piorou muito! A gente se vê concorrendo com outros deficientes. A empresa fala: eu quero deficiência leve! Isso pra gente é horrível! (Márcia) 


\subsubsection{O cotidiano: marcas que ficaram}

Além do convívio na escola, na família e no trabalho os sujeitos foram estimulados a falar de outros contextos e as experiências de sentir-se socialmente incluídos ou excluídos.

\section{Infância}

Descreveram o período da infância, por meio das lembranças de brincadeiras em grupo ou às vezes solitárias, acrescentando alguns comentários sobre as limitações decorrentes da deficiência, sua reação e a de seus amigos.

Sempre andei normal sem ajuda e na infância não teve nenhuma rejeição porque eu sempre fui muito curiosa. É um desafio você vai e quer mostrar o melhor. Só nadar, nadar eu não sei. Foi uma coisa que eu não busquei muito, mas as brincadeiras! Era normal a gente brincava de tudo um pouco. Brincava de "pic esconde" de correr "pegar pitula”. Tinha amigos, bastante! Na educação física do colégio, participava também. Só quando tinha uma atividade que exigisse equilíbrio. Eu ando normal, mas ficar parada com equilíbrio eu não consigo. A única coisa que tinha um pouco de diferença era só nessas horas. (Ana)

Na minha infância sempre tive poucos amigos. Tinha mudado conheci bastante gente, jogava futebol com a turma no final de semana. Mas no começo acabava fugindo um pouco, porque as pessoas não vêem a deficiência assim... então fugia um pouco. Chegavam: ah vamos lá e tal. E eu: ah hoje não vai dar para eu sair e tal. Eu tinha um certo receio de me aproximar e a pessoa perceber a minha deficiencia. Quando o pessoal falava vamos sair e tal, acho que também por conta da minha timidez, não sei! Tinha uns 14 anos. Tinha poucos amigos. (Paulo)

Estudei em uma escola para cegos, porém no dia a dia eu ficava na rua com meus amigos que enxergavam. Brincava de tudo, então tinha esses dois lados, as duas situações. Sempre fiquei com pessoas que enxergam e pessoas que não. Nunca tive nenhum problema assim de adaptação. Eu até preferia, eu tinha mais amigos cegos. Agora não sei porque, deu um sumiço! (Márcia) 
Com as crianças da vizinhança? Era normal, eu morava na Freguesia morei muito tempo. As pessoas hoje da minha rua... tem amizade até hoje... Na verdade eu sempre brinquei mais sozinho. Então eu tinha meus carrinhos, meus trenzinhos, sempre mais em casa. No clube ia mais pra nadar. (José)

Até nisso fui beneficiado por morar no interior e ter a minha deficiência. Eu sempre fui tratado como igual pelos colegas e pela minha família, primos, tudo. O que tinha na época que eu não gostava era aqueles apelidos, " quatro olho”, quando colocava o óculos. Mas fora isso todo mundo me respeitava! Então aprendi a andar de bicicleta. Sempre brinquei de subir em árvore, tanto que naquela época na casa da minha mãe tinha dois pés de abacate, altos mesmo e que se encontravam. Meus primos com 7, 9 anos chamavam para passar de um pé para outro e eu ia! Tanto que o primo que deu a idéia caiu do pé de abacate e eu não! (risos) A infância foi normal, tranqüilo! Jogava bola... (Henrique)

Márcia relata muitos detalhes de brincadeiras, não se privando da companhia de outras crianças ou jogos de sua época.

Andei de patins, de carrinho de rolemã de bicicleta. Quando eu comprei uma nova que tinha uma garupa, o que a gente fazia. Eu ia pedalando, abaixava a cabeça no guidão, minha amiga sentava na garupa e ia dirigindo, ia para o museu em todo lugar lá do Ipiranga. E depois trocava um pouco eu sentava atrás e ela ia pedalando e dirigindo. Eu brincava de vídeo game, os amigos do meu irmão deixavam o vídeo game em casa. É interessante que eu decorava os caminhos do vídeo game. Era o Atari, então era mais fácil. Eu sabia os caminhos então eu brincava. Sempre brinquei de tudo, escondeesconde, a gente parava os ônibus que iam para a garagem, pegava a carona. De tudo que eles brincavam eu brincava junto, não tinha nenhum deficiente, só eu. E outra a criança cega ela tem menos medo do que um adulto que não enxerga. Tipo eu fazia coisas na época que hoje eu não faria. (Márcia)

Marcos manifestou dificuldades para trazer suas lembranças, mas quando foi solicitado para falar da infância fez o seguinte relato: 
Eu lembro quando a gente ia no playcenter. Tinha a casa de espelho. Meu primo falou vou sair primeiro que todo mundo. Quando eu sai, fiquei lá fora esperando! Ele se perdeu. Porque é assim. Você não pode olhar pra frente, mete a cara! (Marcos)

Estimulado a lembrar outros fatos, acrescentou:

Tinha um amigo na rua. Na rua brincava de um monte de coisa... jogava bola com o pessoal. Ah... a gente ficava conversando... era legal. Moravam perto da Bandeirantes. Lembrei agora... Lembrei que tinha um que eu ia todo dia lá. (Marcos)

Mesmo havendo muitas lembranças positivas da infância as pessoas entrevistadas trouxeram também registros de convivência hostil e mostraram como a enfrentaram.

Naquela época tinha os xingamentos às vezes eu deixava falar, às vezes eu reagia: Meu nome não é esse! Dependendo da situação eu engolia o sapo, o brejo inteiro, desde pequeno! Mas depende muito. Esse tipo de brincadeira pejorativa vai ter mesmo! Até hoje você tem que ter habilidade de administrar isso, porque senão você vai ter brigar com todo mundo todo dia! (Henrique)

Até os vizinhos dele zombavam muito! Ele só tinha um amigo fora da escola que ficava sempre junto. Quando ele ia brincar eles falavam: o surdo tem que ficar fora. E ele ficava fora ficava sozinho vendo eles brincarem. Tinha um lugar que eles jogavam futebol. Ele queria jogar e eles falavam: Não, o surdo não! Surdinho não vai jogar! E ele falava para o zelador que eles não deixavam jogar. Ai teve uma época que o zelador proibiu até eles de jogarem lá: Se ele não vai jogar vocês também não vão jogar! E cortou o jogo no condomínio deles. Alguns amigos falaram que foram a favor dessa decisão e depois com o tempo deixaram ele jogar. E ele se tornou o líder da turma do futebol e de vôlei. Ele falou que ele sabe que nas costas eles falavam dele. Ele sabe disso, mas com o tempo eles passaram a ter uma amizade mais normal. (intérprete de Alex) 
Talvez o depoimento de Márcia foi o que melhor explicitou essa relação envolvendo ora a proximidade ora o afastamento entre as crianças e que nem por isso a excluía do convívio em grupo.

Criança é muito melhor! Criança é mais sincera, ela é melhor como pessoa. Porque o adulto vai criando uns preconceitos muito estranhos e além de tudo ele é falso! Você nunca sabe se ele realmente está fazendo aquilo porque ele é seu amigo, ou porque ele está fazendo aquilo para ficar bem com os outros, ou com ele mesmo. A criança não! No dia que ela está a fim de brincar ela brinca, ela te chama, No dia que não, ela fala ah! fica aí. A criança é bem honesta e é bem leal. (Márcia)

Lembranças da infância trouxeram também fatos inusitados, revelando comportamentos inesperados no bairro em que Alex morou.

Na época ele usava aparelho e teve um dia que ele estava na rua apareceram dois ladrões. Eram meninos que conheciam o pessoal ali e aí cumprimentaram. Ele ficou morrendo de medo. E aí quando viram que ele era surdo falaram: não vou roubar você não! Ai abraçaram ele e até falaram que se alguém maltratasse ele era pra ele falar porque não queriam que brigassem com ele. Ele não conhecia esses rapazes, mas sabia que eles eram ladrões e não fizeram nada com ele. (intérprete de Alex)

Uma questão surgida na entrevista com Márcia e Alex foi a convivência entre pessoas com e sem deficiência, quando a deficiência envolve um processo de identificação. Os sujeitos referem a ser surdo ou cego, e o seu oposto, ser ouvinte ou vidente. Fizeram referência à forma de convívio como uma escolha.

Mas eu preferia sempre ter amigos cegos. Porque é diferente assim. As pessoas não riem das mesmas coisas. Então se eu estou num lugar, um passeio ou uma balada, posso estar com uma pessoa que enxerga, só que assim ela vai se divertir com coisas que eu não vou me divertir. Porque a cabeça é outra. O cego não! Vai rir da mesma coisa que eu entendeu ? Então é diferente. Então eu preferia antes, agora já não sei mais... já perdi tantos dos meus amigos cegos, porque uns casaram outros se mudaram. E eu não vou mais em associação então acabou... eu acabei fazendo o papel da pessoa 
que enxerga. Ai eu falo: ah! gente eu não quero mais trabalhar com vocês, eu quero os meus amigos cegos pelo amor de Deus, eu estou ficando muito mal acostumada, leva e traz, leva e traz! (Márcia)

\section{Experiências de sentimentos de inclusão e de exclusão}

As entrevistas tentaram identificar em meio às experiências significativas aquelas que marcaram pelo sentimento de inclusão ou de exclusão. Levantaram passagens importantes em que os relatos falam diretamente da condição de ter uma deficiência, outras da vida escolar, outras de vivência na adolescência e momentos diversos do cotidiano.

\section{...sobre a deficiência}

A deficiência gera limites com os quais as pessoas lidam de modo diferente. Em comum as pessoas entrevistadas apresentam esses limites desde o nascimento cada qual refletindo de maneira singular em suas vidas. $\mathrm{O}$ fato de conseguir um apoio para reduzir a desvantagem representou muito para Henrique e Paulo.

Marcante foi o fato de eu conseguir a primeira telelupa. Aquilo ali não tem preço! Mesmo! Na época foi aqui no Largo do Arouche, o Dr Raul indicou a ótica que trabalhava com importação. Depois de 2 meses aguardei fiquei esperando contando os minutos. Quando fui buscar, ai lá atrás tinha um espelho, um vidro e eu vi a marca de um cartão de crédito! O coração bateu mais forte, acelerado. Foi a primeira vez que realmente eu enxerguei algo de longe! Foi uma experiência singular em todos os sentidos! (Henrique)

Paulo ressalta na vida escolar a experiência da breve permanência em uma sala especial e o retorno à sala comum, que o fez sentir-se menos deficiente.

Lembro muito dessa época desses 2 meses que eu fiquei na classe especial. Hoje eu avalio assim eu sou um privilegiado. Deus me deu um privilégio porque eu tenho 30\% de audição. Tem pessoa que não tem nada, não escutam nada. Então eu ganhei 30\%, 
não perdi 70\%! Hoje na minha cabeça eu tenho isso. Ganhei 30\% em vez de pensar que eu perdi $70 \%$. (Paulo)

Os depoimentos evidenciaram o preconceito da sociedade em vários momentos. José e Ana ressaltaram a questão do próprio preconceito a ser superado.

Eu tinha preconceito de mim mesmo não usava short em hipótese nenhuma. Acho que tinha uns 12, 13 anos. Hoje é mais ou menos. Na rua no shopping, percebo o jeito de olhar das pessoas. Já foi mais dificil, ter preconceito de mim. Fui superando um pouco porque você não tem como mudar isso! Ah! Eu sou assim, não tem como mudar. Eu fui por mim mesmo enfrentando! (José)

Quando você chega em um ambiente e as pessoas não perguntam sobre a deficiência. Porque tem pessoas que mal te conhece já chega e questiona. Tudo bem é uma curiosidade para quem não conhece. Mas acho assim que você tem que conhecer a pessoa e não avaliar! (Ana)

Eu sentia preconceito hoje não mais. Porque eu gosto de mim. Primeiro a gente tem que se dar o valor. Eu não queria ser vista como uma coitada entendeu. Então eu mostrava força de vontade de querer aprender. Às vezes eu sentia que as pessoas tinham esse preconceito. Hoje eu já vejo assim que devido à lei muitos tentam não passar para nós esse tipo de preconceito, mas ele ainda existe. (Ana)

\section{Experiências de inclusão}

na escola...

A escola foi o cenário que deixou muitas marcas algumas, de sofrimento e outras positivas. Foi no contexto da escola que Henrique sentiu-se desafiado a se expor e enfrentar um público passando por uma experiência de sentir-se aceito e descobrir novas habilidades. Em outro caso, o comportamento solidário de uma colega fez a diferença para Márcia que não deixou de ressaltar também os momentos difíceis que já havia passado. 
No final de ano eu fiquei de exame em uma matéria e a professora falou que eu tinha que fazer um trabalho e apresentar também! Tudo bem mas eu nunca tinha ficado na frente, ia ser um desafio! Lembro que só eu fiquei na frente e os colegas assistindo. Depois agradeceram, você falou muito bem e tal Aí eu percebi não só o fato de ser aceito. Eu percebi afinidade com a comunicação verbal, oral, escrita, porque eu gosto muito de ler e de vez em quando escrevo alguns poemas. Então isso foi me dando incentivo, chegar lá na frente e deslanchar. (Henrique)

Marcante de positivo foi no ensino médio quando eu fiquei de recuperação em matemática, tinha umas meninas lá na classe que eu nem esperava e se propuseram a me dar aulas antes, fui na casa delas. E também uma menina no segundo ou terceiro ano, que ela nem estudava com a gente e ela foi super gentil, ela nos ajudou a mim e a minha amiga que estudávamos juntas e a gente teve aula particular com ela! Então assim essa pessoa foi importante num momento que a gente não tinha pra quem pedir! Uma pessoa que de graça mesmo, acho que ela nem cobrou, ela chamava acho que Sandra, ela era super calma. Era uma pessoa que a gente nem conhecia e ofereceu ajuda! Era época do colegial. (Márcia)

Na sexta série eu tinha uma professora que percebia quando eu estava me sentindo excluido da sala e me chamava pra participar. Oh vem aqui um pouquinho, fazia brincadeira para eu participar e fazer parte do grupo! Na sala de aula mesmo isso era legal, ela dava as atividades. Oh, vem aqui participar com todo mundo e tal. Era uma pessoa que te incluía mesmo, teve aquela abertura. (Paulo)

\section{na infância...}

Todos foram solicitados a falar das brincadeiras de infância e trouxeram boas ou más recordações, sendo Márcia quem as considerou como marcas significativas.

Para mim uma forma de inclusão foi a infância. Porque eu estava incluída no contexto do bairro, das crianças! Eu sempre fui bem aceita não tive nenhum problema e quando tinha a gente resolvia no tapa, a gente brigava na rua. Então pra mim a inclusão na infância é muito marcante porque realmente criança não tem (faz) diferença, se ela 
tiver que xingar ela te xinga, se ela tiver que ajudar ela te ajuda. Se ela não quiser também ela não te ajuda, ela é totalmente honesta! Ela não é falsa. Ela nunca vai dizer um sim querendo dizer um não, entendeu? Ela é verdadeira. Então pra mim isso que é a maior prova de inclusão, porque não adianta pra mim ah faz tudo me ajuda em tudo, mas você percebe que a pessoa não tem aquela sinceridade no que faz. Ela faz por outros motivos e não porque realmente quer. Para mim melhor dizer: ah Márcia hoje não! Veja quem pode te ajudar ai! Você ganha mais pontos comigo me falando isso que fazer as coisa e eu sabendo que você não quer fazer! (Márcia)

\section{no trabalho...}

A vida profissional foi lembrada por José, Marcos, Henrique e Márcia como meio de experiências gratificantes de inclusão, quando sentiram um tratamento de igualdade em relação a outros funcionários participando das atividades de grupo na empresa, ou vendo o reconhecimento de seu trabalho.

Ah! Aqui na empresa uma vez a gente fez o treinamento da brigada de incêndio. Fui a campo fazer o treinamento Ai eu comecei a observar e falei não vou conseguir. Daí a pessoa que comandava falou: Não! Você vai sim! E fiz todo o treinamento! Foi no ano passado! (José)

Gosto que as pessoas respeita... assim. Eu gosto de qualquer lugar, que a pessoa me entende que eu falo. Muita gente (entende ele) Na família e no serviço! Quando eu estava trabalhando eu fui no rally. Foi bom porque a empresa alugou 15, 20 carros. Tinha uma palestra que eu fui lá. Juntou um grupo e fui no rally. Tinha o motorista e eu fui atrás. Falava aqui não, ali! Senti bem. Porque assim, é uma coisa esportiva, como é que a gente fala, é uma coisa de distração. Tem uma fita gravada que me deram está guardada. O chefe deu! (Marcos)

Foi no primeiro emprego mesmo, no trabalho Porque mesmo sem as pessoas saberem, inclusive eu, que eu era deficiente, elas viam que aquele trabalho que estava sendo feito era um pouco mais demorado porém tinha qualidade Tanto que várias vezes o meu chefe falava, se não fosse essa sua deficiência você podia ser até desenhista aqui 
dentro. Então como depende da visão seria difícil mas para tirar as cópias, modéstia à parte, fazia bem. (Henrique)

No profissional marcante foi a oportunidade que a empresa me deu para cuidar da Central de Atendimento ao Consumidor, porque eu sempre achei que ia ficar só no atendimento! Então foi uma surpresa, eu não esperava! Na verdade a gente sabe que tem aquele conhecimento, mas acha que as pessoas não confiam no que a gente faz porque as pessoas são muito visuais! (Márcia)

no ambiente em geral...

A deficiência como uma condição vivida cotidianamente pelas pessoas entrevistadas, gerou relatos interessantes de inclusão como descreve Alex. Porém como pessoa surda ele não acredita na plena inclusão.

Eram amigos mas as turmas eram cada vez diferentes. O único momento que sentia mais incluído era no meio dos homens quando eles falavam palavrão e eles aprendiam em LIBRAS. Ele nunca se sentiu totalmente incluido com os ouvintes porque tem uma identidade do surdo. (intérprete de Alex)

\section{Experiências de exclusão}

na escola...

Foram diversos relatos envolvendo sentimentos de exclusão no ambiente escolar. Mas Paulo destacou como experiência marcante a intolerância do grupo:

Teve uma que eu lembro bastante. Na escola as próprias pessoas mais próximas perguntavam, eu respondia: tenho deficiência auditiva, não escuto. Mas algumas pessoas não sabiam na sala de aula. Então teve um dia que a gente estava no pátio e uma pessoa da turma comentou: ah quanto você tem?E eu não entendi a pergunta. Perguntou de novo e eu não entendi. Daí as pessoas saíram de perto. Falaram: você é 
surdo então! Sai fora. Aquilo me marcou bastante porque todo mundo saiu de perto, acabei ficando sozinho ali. (Paulo)

O relacionamento conflituoso com o professor já descrito em muitos relatos e ganhou uma dimensão mais significativa para Alex.

Ele tem trauma de uma professora ruim da $4^{o}$ série. Era uma professora de matemática e ele adorava matemática. Só tirava boas notas. Ai quando ele tirava 10 ele gritava, comemorava. A professora ficou com raiva dessa comemoração e abaixou a nota dele para nove e meio E aí ele falou: Puxa vida! Ele reclamou e ela abaixou para nove. Aí ele ficou quieto! Ficou com muita raiva dela, uma coisa que ele ficou traumatizado até hoje. Ele continuou indo bem mas não esqueceu dessa professora! Ela estava errada! Ele estava feliz deveria ter parabenizado. Estudava na DERDIC e todas as professoras eram muito boas mas essa ele ficou com trauma. (intérprete de Alex)

Márcia acrescenta uma opinião mais crítica frente à exclusão sentida no relacionamento da faculdade.

Para mim foi uma experiência negativa de inclusão na faculdade também. Porque são pessoas que estudam que vão formar opinião, vão ter cargos de chefia e têm uma cabeça tão pequena! (Márcia)

\section{no trabalho...}

Falar do trabalho trouxe muitas lembranças, entre elas a experiência de sentir-se discriminado no momento da entrevista de emprego, fato que foi marcante para Márcia.

Acho que foram as entrevistas de emprego, daquelas que você vai e percebe que a entrevista de outra pessoa durou 20 minutos e a sua durou 5 entendeu? A pessoa fica com aquela cara de quem está vendo uma coisa do outro mundo! (Márcia)

\section{na adolescência...}

Os sujeitos lembram da adolescência como um período especial de relações sociais. Trouxeram relatos da fase de enamorar e a hostilidade do jovem. A família de Marcos tomou providências mais firmes. 
Nessa escola eu me interessei por uma garota. Falei com ela que estava gostando dela, aí eu recebi uma paulada! Mas bem dada. Ela falou assim: vamos supor a gente começa a namorar, como você vai me encontrar se você não enxerga? Falou na cara! Aí eu falei umas coisas pra ela, respeitando a pessoa dela tudo! Tinha uma aula vaga, ficou assim ao redor com todos os colegas escutando o que eu falava pra ela. Você acha que eu venho aqui no Jabaquara, com a minha mãe? Que ela me traz aqui na escola? Eu trabalho, você acha que a minha mãe me pega na minha mão, e eu entro lá às 7 horas e ela vai me pegar às 5 da tarde? Eu vou a Shopping, assisto cinema, eu tenho que assistir na primeira ou segunda fila! Se não eu não enxergo! E quem vai me levar no shopping? Você acha que alguém me carrega no colo? Aí ela foi ficando sem graça! (Henrique)

Assim o pessoal gosta de me provocar. Eu tinha uns 14 assim, veio sem educação, xingavam, ofendiam. Teve uns que gostam de brincar. Eu fico nervoso... relaxa, depois esquece... passa. Quem faz isso essa brincadeira... faz sem pensar... (Marcos)

Tratar mal nunca mais mesmo porque se a irmã souber, ela vira uma fera! Ela chegou a abrir um processo uma vez. Os rapazes foram chamados na delegacia. Era um grupinho e sempre andaram juntos com o Marcos em Santos. E de repente começaram a falar besteira. Mas eram dois ou três que já estavam mal encaminhados. Negócio de drogas e tal! Uma amiga do irmão que participava do grupinho do orkut que avisou minha filha. A irmã falou: eles tem que pagar. Mas só ficou na parte da bronca! Foram chamados! Falta cidadania! Falaram coisa terríveis. (pais de Marcos)

\section{no ambiente em geral...}

Em lugares públicos observam o preconceito a desinformação das pessoa ao redor. Alex busca a identificação com o grupo de surdos, sentindo dificuldade para compartilhar formas diferentes de comunicação.

Uma vez ele paquerou uma mulher ouvinte e falou que ela era bonita, mas ela tratou mal e zombou dos sinais dele. Ele nunca se sentiu totalmente incluído com os ouvintes porque tem uma identidade do surdo. Depois ele casou com uma ouvinte que sabia 
LIBRAS e tiveram um filho ouvinte. Eles dividiam, ela participava com ele da comunidade surda e quando eles saíam com o grupo dos ouvintes ele não se sentia do mesmo modo, ficava de fora, eram amigos dela... Mas na comunidade surda ela ficava à vontade porque a mulher sabia a língua dele e ele não entrava na conversa dela, na lingua deles, a mulher dele ficava como intérprete. (intérprete de Alex)

Ah! Sim é... eu senti isso lá em Osasco. Teve um evento para jovens que queriam fazer curso militar nas forças armadas. Ia ter uma palestra e eu cheguei lá, o cara falou: Não pode, deficiente não pode! Eu falei: mas eu posso assistir a palestra? Ele falou: pode! Fiquei lá e assisti. (José)

Na vida pessoal o que às vezes me choca é estar num ambiente com minhas amigas, $e$ alguém me olha e já fica meio com receio. Depois que me conhece vê que eu sou uma pessoa legal aí já aceita. Vamos supor eu estou numa festa as pessoas me vêem de cintura para cima Aí eu estou sentada e por causa da mesa a pessoa não viu de perto, não viu a deficiência ainda. Então aproxima aí vem conversar ai de repente vê a deficiência, leva aquele susto. (Ana)

\subsubsection{Reflexões sobre o movimento de inclusão social das pessoas com deficiência}

As opiniões sobre a inclusão de pessoas com deficiência na sociedade mobilizou temas sobre a acessibilidade arquitetônica, escola inclusiva e o olhar de preconceito da sociedade.

Pessoas com Márcia, que possui a mobilidade reduzida, em função da deficiência visual, apontam suas dificuldades de locomoção e de transporte em uma metrópole como São Paulo de forma bastante crítica.

Falar que o governo está adaptando o centro de São Paulo com duas calçadas com o piso tátil e o resto? A gente anda só nas duas? E a periferia as calçadas do meu bairro! Não dá para andar porque tem portão aberto, árvore, buraco, cachorro, lixo na calçada, degrau, então você tem que andar na rua! Vamos fazer, então vamos fazer em tudo! Agora põe dois ou três ônibus na rua! Outro dia o menino estava esperando, 
chegou o troleibus ele não foi mas eu fui! Porque ele estava esperando o ônibus com piso rebaixado! E se ele tem hora marcada! Fazem alguma coisa para falar que estamos incluindo, mas está tudo igual! (Márcia)

O depoimento de Alex, Márcia e dos pais de Marcos, revelam a preocupação com a qualidade da educação para as pessoas com deficiência alertando sobre o cuidado a ser tomado com o tema educação inclusiva especialmente no sistema público. Alex e Márcia deixam clara sua posição contrária à inclusão na escola regular desde o início e os pais de Marcos são favoráveis às escolas inclusivas, pela oportunidade de aprendizagem com as diferenças.

O mais perigoso é a inclusão na educação. Da educação infantil até o ensino fundamental deve ser feita em escola especial. Do colegial para frente até a faculdade a inclusão pode ser normal (na escola comum) Isso porque eles (os surdos) tem um problema lingüistico e então tem que aprender primeiro a LIBRAS depois a língua portuguesa. (intérprete de Alex)

Em relação à inclusão no $1^{o}$ colegial é importante o surdo estar incluído com intérprete. O grande problema é que a promotoria recebeu alguns processos que precisa ter intérprete, quer incluir todos os alunos na escola regular. Mas não tem intérprete preparado, boa parte não tem preparo. Além disso o número necessário é grande demais. Por isso ele é contra. É a favor que, da educação infantil até a oitava série, não tenha inclusão. As crianças ficariam nas escolas especiais da prefeitura com professoras que sabem LIBRAS. (intérprete de Alex)

As pessoas falam de inclusão, que a escola especial segrega, segrega coisa nenhuma! Você tem as duas coisas. Tudo bem que aquele que é interno deixa de ter um pouco de convivência com as crianças que enxergam. Mas digamos que em termos de custo $e$ beneficio, você se desenvolve melhor na infância com o colégio especial. Você vai ter a parte motora você não vai ser, digamos assim, um cego bobo, um cego que chega e ali fica. Não! Você vai ser uma pessoa que pode participar das coisas normalmente. Normalmente não mas da mesma forma que os outros, com algumas limitações! Eu sou 
totalmente contra a inclusão de pessoas em escola comum desde o começo. Eu não acho que é bom. (Márcia)

Agora as escolas aceitam, eu acho interessante devia ter mais classes, mais informação. A escola deve receber todos alunos, porque isso traz benefício para quem não tem nenhum problema, a integração, aprende a respeitar o outro e esse outro se espelhar naquele. Há uma convivência normal. (pais de Marcos)

Esses depoimentos são complementados com comentários que revelam a percepção crítica das condições da escola pública, a qualidade do projeto pedagógico e o despreparo dos professores.

Tem seis escolas públicas que ensinam os surdos. E ele visitou essas escolas, viu que dentro dessas escolas hoje os alunos usam drogas, fazem fofoca! É muito bagunçado, eles tem dificuldades nos estudos! Ele acha que é por causa da falta de esportes. Acha que o esporte equilibra a educação. Se tiver que só estudar eles não conseguem, então tem que ter esse equilíbrio. Faz um pouco de esporte, a cabeça mais saudável, diminui o consumo de drogas. Essas escolas da prefeitura não tem aulas de educação física. (intérprete de Alex)

A escola pública está com dificuldade já de cuidar dos alunos sem deficiência, é difícil Já não é fácil numa classe de 15, agora coloca numa classe de 40 alunos! Tem além da deficiência intelectual, ou mental, tem aquelas na visão, física, audição. E a professora às vezes não percebe que ela não ouve. (pais de Marcos)

Então essas crianças cegas que estudam em uma escola regular, na prefeitura ou no estado, tudo bem, é a lei da inclusão, gostam de dizer que vai ficar integrado!. Não vai ficar coisa nenhuma porque você (o cego) não vai ter uma vida normal. A única coisa que você vai ser é um cego tentando estudar numa escola com pessoas diferentes dele. Então o que acontece: na hora de uma brincadeira, na hora de ter as atividades em que você vai ter que se locomover, que são as atividades de maior integração com as crianças, vão te colocar sentado! Porque vão tentar uma vez com você e você não vai conseguir porque você não tem esse hábito. Comigo eu já conseguia porque já tinha 
esse hábito, porque eu já fazia no colégio que eu estudava. Então a teoria é diferente da prática. (Márcia)

Falar do movimento de inclusão significou para alguns lembrar do preconceito da sociedade, para outros levantar críticas ao governo, ressaltar a importância da legislação, da necessidade de conscientização da população através de uma maior divulgação de informações.

Tem preconceito ainda e não depende do nível das pessoas. Às vezes a gente fala que o pessoal de instrução mais baixa é que tem um pouco mais de receio, mas o pessoal também de posição mais alta também tem preconceito. Existe ainda, principalmente com a síndrome de Down, não sei se você percebe isso. Tem pessoas que até param para olhar. Minha mãe falava que antigamente ficavam fechadas dentro de casa! Eu sinto que as pessoas estão um pouco mais informadas, estão aceitando melhor. (pais de Marcos)

E a inclusão em termos mais gerais acho que é tudo fachada mesmo, porque o que inclui é a vivência é o convívio, é você mostrar mesmo no dia a dia com as pessoas como é que funciona. Campanha até resolveria, mas tem tanta coisa a ser feita nesse sentido! Colocam um orelhão na Avenida Paulista para falar que tem orelhão adaptado! Colocam o piso tátil na calçada... Pra mim isso não é incluir, isso é fachada serve pra inglês ver, para nós mesmos não serve! (Márcia)

No Brasil as coisas só funcionam assim à base de lei, de multas, fiscalização em cima! Porque as pessoas não querem saber! Mesmo aquelas que são mais deficientes do que eu, que falta um braço, falta a mão, as pessoas não respeitam. Não dão o lugar, não deixa passar primeiro. Imagina eu então que para elas não é nada! No Carrefour frente a minha casa toda vez eu tenho que mostrar um cartãozinho, mostrando que eu sou deficiente! Oh moço você não pode vir nesse caixa porque você não é deficiente. Claro que sou! Não o senhor só tem o olho torto. Eu tiro o cartãozinho: ah o senhor me desculpe! Falta informação. (Henrique) 
No meu modo de ver acho que a sociedade tem muito a fazer para estar incluindo as pessoas que tem deficiência, no mercado de trabalho na escola em qualquer setor. Porque você não ouve falar de deficiência, não comentam. São poucas campanhas para conscientizar as pessoas que tem deficiência. Que a sociedade tem diferença um é alto outro é magro, toda e qualquer diferença. Você não vê falar muito disso. Ou que a inclusão tem uma cota, mas é porque tem uma lei! Acho que tem que se fazer uma campanha para conscientizar as pessoas todo mundo que existe a diferença, tem pessoas deficientes, até pra gente estar sabendo como lidar. (Paulo)

Mas não é toda escola que tem essa proposta de inclusão. Tem que pesquisar! Lembra da novela? A televisão deu um exemplo sensacional. Passar essa coisa da inclusão! Mas ainda é difícil. Devia ter mais divulgação. (pais de Marcos)

Ter uma deficiência traz diferença. Principalmente aqui no Brasil, porque as pessoas ainda estão muito mal informadas do que vem a ser uma deficiência. Porque de um modo geral, não é uma crítica, mas de um modo geral para o povão deficiente é aquele que não tem uma perna, aquele que é cego, que não tem uma orelha, é aquele que faltam 2, 3 dedos, que não tem braço. Então a deficiência é isso. E a gente sabe que tem vários níveis de deficiência, igual ao meu caso! Estou no meio termo: eu não sou cego e nem enxergo bem! Eu estou bem no meio. Então tem gente que fala pra mim e fala até hoje: mas você não é deficiente! Que deficiência você tem? Eu falo minha deficiência está na cara! Aí ele fala mas você só tem o olho torto! Na minha leitura falta informação, saber que tem níveis diferentes da deficiência. A minha deficiência é baixa visão. (Henrique)

As opiniões e comentários sobre a inclusão revelaram ainda, uma conscientização gradativa da própria pessoa com deficiência como protagonista desse processo. Alguns iniciam sua participação timidamente, outros defendem a mudança no cotidiano da convivência, enquanto a ocupação de espaços políticos de pessoas com deficiência vai fortalecendo o movimento de inclusão, abrindo novos caminhos.

Eu conheci isso há pouco tempo como falei. Comecei a acompanhar mais indo a alguns eventos. Eu acho que é um trabalho que tem que ser feito porque esperar alguma coisa 
dos órgãos governamentais! Acho que a sociedade é que tem que batalhar mais pela inclusão. Tem que ter a luta, o pessoal tem que corre atrás mesmo. Eu vi casos de empresas com inclusão de deficiências diversas. Ela tinha casos de deficiência mental. Eu jamais imaginava que uma pessoa dessa ia conseguir estar empregada. Eu não acreditava nisso. Foi uma surpresa! Fui descobrindo as coisas. Tinha um conhecimento da lei mas muito superficial. Eu não sabia nada. Vim conhecer isso nos últimos anos. Percebo algumas medidas de acessibilidade no metrô de São Paulo. Tenho participado mais para fazer parte da discussão mas não estou associado a nenhum órgão. (José)

Para mim ainda estamos longe mas é uma situação cultural, falta continuar. Vai fazendo um pouquinho aqui, ali, para dizer que fez. Acho que sou pessimista, porque eu acho que a inclusão quem faz sou eu no dia a dia porque se eu for depender de alguém, órgão governamental...

Assistir uma palestra na empresa é bonito, sensibiliza, o povo chora, ai sai da palestra, vê um cego na rua e nem pergunta se o infeliz quer atravessar! Então do que serviu? Você não mudou o comportamento, teve só a reação aquela emoção imediata, mas no dia a dia! Tem gente que passa por mim nem bom dia dá. O que funciona é o dia a dia. Aí é que você vai incluindo, porque vivenciando acabo incluindo outros. Se eles vêem outro deficiente na rua eles sabem como proceder, tanto é que a gente sabe quando alguém vai ajudar a gente na rua, a gente sabe se ela conhece um deficiente ou não! Alguém perguntou para o meu amigo se ele tinha amigo deficiente porque ele guiava tão bem! Então quem faz a inclusão somos nós! Devagarzinho com o convívio das pessoas com deficiência. Mesmo aquele que fica no seu mundinho, entendeu. Aquele que vai no vizinho pedir um açúcar emprestado! Tem deficiente que não sai de casa! (Márcia)

Na última eleição ele se candidatou a deputado federal, não ganhou mas teve um número expressivo de votos. Tinha 4 surdos candidatos à deputado. Ele foi o único surdo candidato de São Paulo. Só conseguiu candidatar porque teve intérprete. Tinha que participar de muitas reuniões e se não tivesse ele não conseguiria. Por causa da eleição foi convidado para a secretaria. As pessoas de lá não conhecem muito a cultura surda eles discutem a inclusão mas não conhecem bem. (intérprete de Alex) 
Depois que entrou, abriu uma portaria para fazer o festival esportivo e cultural dos alunos surdos. No ano passado participaram 1500 surdos de 20 escolas: 6 da prefeitura, outras particulares e também do interior. Só na capital existem 1300 alunos surdos: incluídos tem 400 e no $1^{\circ}$ colegial incluidos são 60. Você vê a diferença. Muitos alunos surdos não vão para o colegial porque não tem intérprete. A escola da prefeitura que é para classe mais baixa e então ele esta tentando fazer um projeto para por em cada escola uma fonoaudióloga e uma psicóloga. Porque ele sabe que os alunos não tem condições de pagar e é importante ter esses dois tipos de tratamento. São para as seis escolas da rede que tem as classes de surdos. (intérprete de Alex)

O depoimento de Márcia evidencia com clareza o lugar da pessoa com deficiência: a decisão e a escolha ainda pertencem ao outro.

Quando você vai com uma pessoa que enxerga ela vê tudo o que você quer. Então se ela quer ver você sentada então tem que sentar. Ela não vai falar se você quer ficar de pé. Não! senta aqui. Senta aqui que é melhor Então a pessoa quer decidir por você! (Márcia) 


\section{DISCUSSÃO DOS RESULTADOS}

O registro autobiográfico como método de pesquisa trouxe conteúdos valiosos para análise do processo de inclusão das pessoas com deficiência entrevistadas neste estudo. Da vida escolar à vida profissional, os relatos das experiências vividas revelaram marcas, algumas positivas, outras negativas, deixando lições de aprendizado tanto para aquele que possui a deficiência, como para os que convivem com ele. Pais, irmãos, amigos, professores, gestores e colegas de trabalho, todos fizeram ou fazem ainda parte dessas histórias.

A partir de histórias de inclusão bem sucedidas de pessoas adultas com deficiência física, intelectual ou sensorial, que atingiram a autonomia e se encontram hoje inseridas no mercado de trabalho, podemos revisitar o lugar da escola, o ambiente de trabalho, o cotidiano social e refletir sobre aspectos facilitadores e dificultadores enfrentados pelos sujeitos.

Nessa discussão reconstruo o caminho da inclusão em três dimensões: direito à educação, direito ao trabalho e direito de ser diferente. Incluo esta última dimensão, considerando os elementos que foram participando das trajetórias de inclusão de cada sujeito e construindo a identidade de sua diferença: a família, e o relacionamento social no cotidiano da infância, ou da vida adulta.

\subsection{DIREITO À EDUCAÇÃO}

Analisar o direito à educação de pessoas com deficiência nos obriga a refletir sobre a exclusão social. Neri (2003) indica por meio da análise dos dados do Censo 2000/ IBGE, uma taxa de pessoas com deficiência analfabetas ou semi analfabetas (até 1 ano de estudo) de $27,3 \%$ contra $24,9 \%$ do conjunto da população. Essa taxa aumenta para 42,26 \% no grupo de pessoas com incapacidade acentuada de ouvir, enxergar, com deficiência física ou mental, denominado PPI - Pessoas com Percepção de Incapacidades, conforme foi citado anteriormente. A distância entre pessoas com deficiência e a população sem deficiência aumenta na medida em que aumentam os anos de estudo. Entre as pessoas com deficiência somente $12 \%$ completaram 4 anos de estudo contra os $15 \%$ da população em geral. Completar 8 anos de estudo foi possível apenas para $2,7 \%$ de pessoas com deficiência contra $5,6 \%$ da população sem deficiência. Apenas $2,9 \%$ de pessoas com deficiência chegam a completar de 9 a 11 anos de estudo contra $9,4 \%$ da população. 
Assim os sujeitos da pesquisa constituem, entre as pessoas com deficiência e a população uma minoria. Todos tiveram seu direito à educação garantido; completaram o ensino médio, alguns o ensino técnico, outros, a universidade. Apenas um não concluiu o ensino fundamental devido a suas limitações cognitivas. Os que não têm ensino superior planejam dar continuidade aos estudos para o desenvolvimento profissional. Vivem em uma região de grande desenvolvimento econômico, e estão acima das expectativas estatísticas. O estado de São Paulo encontra-se entre os que possuem um menor percentual de pessoas com deficiência (11,35\% da população); essas pessoas possuem em média, 4,8 anos de estudo encontrando-se acima da média brasileira para o seu grupo, que é de 3,9 anos de estudo. (NÉRI, 2003)

As histórias de vida relatam como os sujeitos percorreram o caminho da educação, as condições, apoios ou barreiras enfrentadas. Todos freqüentaram a escola. Que escola? Regular ou especial? Pública ou particular? Em que ambiente ocorreram as primeiras experiências de vida escolar?

A pesquisa não contemplou a situação sócio- econômica, porém é importante expor alguns dados coletados. Dois sujeitos são oriundos de famílias mais humildes: uma tem mãe analfabeta, e uma com ensino fundamental. As outras mães têm ensino médio e uma, superior. Entre os pais um tem o ensino fundamental incompleto, a maioria, ensino médio e um, superior. Os participantes freqüentaram escolas públicas no interior da Bahia ou de Minas Gerais, e escolas públicas e particulares em São Paulo.

Temos assim heterogeneidade quanto ao aspecto socioeconômico, mas com algo em comum: a deficiência. Com exceção do sujeito com baixa visão, identificada só no final da adolescência, todos têm limitações desde que nasceram ou adquiriram-na no início da infância. As famílias foram em busca de recursos educacionais, públicos ou privados, especializados ou não, logo no início da vida escolar, o que mostra a família como um dos pilares para a inclusão das pessoas com deficiência na educação.

\section{A escolha da escola}

Para quatro famílias a escolha da escola envolveu um impasse: escola comum ou especial?

Para as outras três não houve problema; seus filhos iniciaram "normalmente" na escola: dois com limitação física, que gera somente comprometimento na locomoção, sem 
dependência de cadeira de rodas, e um com baixa visão. Ana lembrou da coragem da mãe que não teve vergonha de expor a filha e Henrique ressalta que sua deficiência não era compreendida como tal.

Nos casos de cegueira e surdez profunda a família, orientada pelos especialistas da saúde, optou por instituições especializadas. Márcia e Alex freqüentaram o Instituto de Cegos

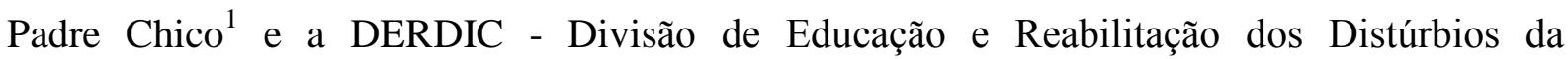
Comunicação $^{2}$. A família de Alex matriculou-o inicialmente na escola regular que o irmão freqüentava, optando pela transferência para escola especializada, quando percebeu que suas dificuldades de comunicação oral afetava o aprendizado e integração com os alunos ouvintes.

Ana, cuja mãe não desejava escondê-la em escola especial, ingressa sem dificuldades na escola pública no final dos anos 80. Famílias que buscaram recursos especializados tiveram acesso à informação e principalmente obtiveram vagas em instituições especializadas particulares.

Em casos de deficiência situada em limiares próximos da normalidade, como a deficiência intelectual de Marcos e o grau moderado de surdez de Paulo, as famílias seguindo ou contrariando orientações de especialistas e professores, preferiram a escola comum, particular. Paulo estudou em classe regular, após uma breve passagem pela sala especial da mesma escola, Marcos em programa alternativo de escola regular e posteriormente na APAESP.

Os sujeitos tiveram escola garantida no sistema comum ou especial, em períodos em que não se discutia a inclusão no Brasil. José e Henrique freqüentaram a escola pública no final dos anos 70 .

Algumas questões se colocam: a natureza e o grau da deficiência foram determinantes para a inclusão no ensino comum? Existe oferta suficiente no ensino comum de recursos necessários para os casos de cegueira ou surdez? As famílias de Márcia ou Alex teriam conseguido as vagas se não tivessem acesso a informações e orientações? O que teriam enfrentado se não tivessem recursos financeiros? Nos anos 70 eram poucas escolas públicas especializadas. As instituições filantrópicas, cobravam mensalidades conforme a renda das famílias, reservando uma cota de gratuidade. Havia filas de espera por vaga nessas

\footnotetext{
${ }^{1}$ Instituto de Cegos Padre Chico - Uma das mais antigas instituições especializadas fundada, em 1927, em São Paulo.

${ }^{2}$ DERDIC - Fundada em 1954 em São Paulo por um grupo de pais e amigos de crianças surdas, foi incorporada, em 1969, à Pontifícia Universidade Católica de São Paulo, sendo considerada centro de referência no tratamento de pessoas com alterações da audição, voz e linguagem.
} 
instituições para as populações de baixa renda. O que teria acontecido com tantas outras crianças carentes com as mesmas deficiências?

O censo escolar realizado pelo MEC em 2001 indica um aumento de $8 \%$ no número de matrículas de alunos com deficiência, quando comparados aos dados de 1999. Entre os alunos matriculados em escolas especiais, $60 \%$ estudam em escola privada e $12 \%$ na rede de ensino público. Esses dados reforçam que temos muito a avançar no acesso à educação pública para as pessoas com deficiência.

A Declaração de Salamanca, na década de 90, ressalta o direito de todos a um ensino de qualidade. Os sujeitos pesquisados tiveram garantia desse direito e a qualidade das experiências vividas no contexto da vida escolar contribuiu com o processo de inclusão.

\section{O apoio da família}

Em todos os entrevistados a deficiência congênita ou adquirida, manifestou-se desde a infância. Em alguns relatos os pais se unem para buscar informações e orientações de recursos de saúde e de educação. Em outros casos, o preconceito foi mais difícil de ser superado. Como Paulo refere, talvez seja esse o motivo de seu esforço para superar as limitações e conseguir um trabalho. Para oferecer o melhor atendimento a família de Márcia mudou-se para o Brasil.

Não ouvimos relatos de superproteção, mas de enfrentamento, busca de informação, orientação, tratamentos de saúde. Observamos que as mães, às vezes contrariando a opinião dos pais, lidaram com a deficiência, apoiaram e incentivaram os estudos e acompanharam de perto o desenvolvimento de seus filhos. No contexto familiar, alguns irmãos tiveram papel decisivo no desenvolvimento e desempenho escolar dos sujeitos entrevistados. Aprenderam LIBRAS- Língua Brasileira de Sinais, o método BRAILE de leitura e escrita, incentivando o aprendizado de seus irmãos com surdez ou cegueira. O convívio familiar caracterizou, para a maioria, uma relação de igualdade entre irmãos, envolvendo primos como companheiros de brincadeiras. As recordações alimentaram sentimentos de segurança, aceitação, fortaleceram as marcas do pertencer mas para alguns, certa mágoa e ressentimento.

O papel da família ganha contornos próprios quando possui um membro com deficiência. Apoio e orientação são fundamentais para promover o desenvolvimento saudável e a auto estima das pessoas com deficiência Os sujeitos entrevistados, independente da condição econômica têm em comum uma história de luta e apoio dos familiares o que 
certamente contribuiu para o êxito na vida escolar, reafirmando a necessidade da participação dos pais na discussão da escola inclusiva.

\section{Escola especializada e escola comum}

O movimento crescente da escola inclusiva enfrenta uma questão de grande complexidade: o atendimento à diversidade, o que envolve o preparo, tanto de alunos e professores, para lidar com a deficiência.

Márcia e Alex consideram que o atendimento nas instituições especializadas fez toda a diferença: conseguiram ser o que são hoje, porque foram estimulados pela escola especial. Recursos como o método Braile de alfabetização, o ensino de Libras, e a convivência com seus pares foram muito valorizados pelos sujeitos. Destacam o projeto pedagógico, voltado para as necessidades especiais do aluno cego ou surdo, como condição imprescindível para a aprendizagem escolar. A socialização na escola especial contribuiu para a identificação com o outro, experiência fundamental para os surdos. Segundo Alex, só assim ele conseguiu estabelecer comunicação. Para Márcia, a convivência e a estimulação no ambiente de alunos cegos, a instrumentaram para a convivência com as crianças videntes e acompanhar os jogos da infância nos espaços do cotidiano.

Os sujeitos com deficiência física freqüentaram desde o início somente o ensino regular. Ana e José não enfrentaram dificuldades para acompanhar as aulas, mas lembram a curiosidade, o desrespeito de colegas, insultos e xingamentos. Entre os professores encontraram profissionais atentos, cuidadosos, como referiu José. Com baixa visão, Henrique se viu, muitas vezes, desacreditado, incompreendido por seus professores. No ensino médio um professor percebeu sua dificuldade e deu-lhe o encaminhamento adequado. Desse profissional ele nunca mais se esqueceu!

Márcia e Alex, com cegueira e surdez, inseridos em classes de alunos sem deficiência, a partir do ensino médio, queixam-se da dificuldade de acompanhar o aprendizado e do ambiente pouco integrador. Porém há relatos de Márcia de apoio dos colegas.

Os depoimentos trazem uma reflexão quanto à qualidade das relações que os sujeitos da pesquisa vivenciaram com seus colegas e professores. Entre crianças ou adultos, a visibilidade da deficiência gerou reações: em alguns, curiosidade, discriminação e rejeição, em outros, solidariedade. Márcia e Henrique com suas limitações de visão receberam muito 
apoio de colegas do ensino médio para ditar as lições, pois nem sempre o professor o fazia. As limitações decorrentes da cegueira ou da surdez despertaram em alguns professores forte resistência, declarando seu despreparo para lidar com a deficiência. Outros procuraram ouvir o aluno especial para poder auxiliá-lo. Isso há 15, 20 anos!

Os depoimentos deixam claro que o espaço escolar é de grande importância para detectar as deficiências, encaminhar para diagnósticos diferenciais, e promover o aprendizado e a integração dessas pessoas. Representa um passo significativo, quando o educador não se coloca de forma hostil diante das necessidades das pessoas com deficiência. Oferecer um espaço de acolhimento e disponibilidade para encontrar juntos as soluções, dar uma atenção especial para estimular um ambiente mais solidário em sala de aula poderiam ter feito toda a diferença para alguns sujeitos! Reconhecer as diferenças individuais e as peculiaridades dos alunos é fundamental.

\section{Preparação para o trabalho}

O percurso na escola indicou garantia de permanência até os sujeitos adquirirem uma qualificação profissional e condições de ingressar no mercado formal de trabalho. Com exceção de Marcos, que ingressa no programa da APAE para capacitação profissional, os sujeitos continuam seu itinerário escolar. Márcia e Alex após o ensino fundamental em instituição especializada ingressam na escola regular. Os sujeitos concluíram o ensino médio, alguns fizeram cursos técnicos nas áreas de Contabilidade, Administração, Processamento de Dados. Dentre eles, três ingressam na universidade: dois concluem Direito e Ciências da Computação, e outro cursa Educação Física.

Os pais de Marcos buscaram uma instituição onde ele pudesse aprender a trabalhar e desenvolver uma atividade profissional. A educação profissional foi realizada em um Centro de Preparação para o Trabalho da APAE - SP e Marcos participou de um programa de vivência profissional em uma empresa multinacional, onde posteriormente foi efetivado. Os pais mostraram-se satisfeitos com o desenvolvimento do filho e com a proposta da instituição.

Outro relato de experiência institucional foi a participação de Márcia em um programa de vivência na LARAMARA. Com experiência profissional, porém desempregada, obteve uma vaga de atendente na empresa parceira desse projeto. 
A educação profissional no campo da deficiência está muito ligada à instituição especializada. Nessa pesquisa poucos utilizaram esses recurso e a maioria obteve uma qualificação profissional na escola regular. Para outras pessoas o apoio da instituição tem sido um meio de capacitar-se e desenvolver as competências profissionais que o mercado exige. Essa possibilidade entretanto, não pode privar as pessoas com deficiência da continuidade de sua formação educacional.

\subsection{DIREITO AO TRABAHO}

O trabalho garante a cidadania e condições dignas de sobrevivência para o ser humano, possibilitando a auto realização do indivíduo como pessoa. Esse é um direito a ser garantido também para as pessoas com deficiência.

No Brasil o art. 34 do Decreto $\mathrm{n}^{\mathrm{o}} 3.298 / 99$ trata do acesso ao trabalho, afirmando como finalidade primordial da política de emprego a inserção da pessoa com deficiência no mercado de trabalho ou sua incorporação ao sistema de produção por meio de trabalho protegido. Considera as necessidades decorrentes da deficiência prevendo vínculos diferentes de trabalho: a "colocação competitiva", mas também a "colocação seletiva" por meio da adoção de apoios e procedimentos especiais, além da formação de cooperativas e trabalho por conta própria.

Grande parte da população com deficiência sobrevive da dependência do Estado, por meio de seus programas de transferência de rendas como o LOAS. (NÉRI, 2003) O benefício institui um salário mínimo para pessoas cuja renda per capita só atinge um quarto do salário mínimo. Observamos casos de pessoas com deficiência preferindo não arriscar-se ao mercado formal de trabalho para não perder o benefício. O Decreto $n^{\circ} 6.214$ de setembro de 2007 tornando temporária a suspensão, poderá incentivar as pessoas com deficiência a ingressar no mercado formal, aproveitando as oportunidades que surgem de vagas reservadas.

A inserção das pessoas com deficiência no trabalho formal é bastante complexa e a qualificação profissional é decisiva para seu ingresso e permanência.

Os sujeitos, na época da realização desta pesquisa, trabalhavam no mercado formal, critério utilizado para participação na amostra. $\mathrm{O}$ caminho da inclusão teve início na escola que lhes garantiu a qualificação para um mercado cada vez mais exigente. Em nenhum momento interromperam sua formação educacional ingressando no mercado de trabalho seguindo o mesmo percurso das pessoas sem deficiência. Alguns começaram a trabalhar 
durante o ensino médio, outros investiram mais tempo na formação profissional, com apoio econômico da família.

A inserção no mercado de trabalho teve início entre 16 a 20 anos, verificando-se que apenas duas pessoas ingressaram de maneira informal. Como meio de sobrevivência desde os 15 anos, Ana já auxiliava a irmã na venda em lanchonete e Márcia foi chamada trabalhar em vendas por telemarketing, ambas sem contrato formal. As atividades laborais não as afastaram do processo de escolarização. Outros sujeitos iniciaram como estagiários ou efetivos. Entre desligamentos e pedidos de demissão todos mantiveram-se no mercado. Somente Marcos trabalhou sempre na mesma empresa. A lei de cotas teria ajudado? É o que discutiremos a seguir.

\section{A lei de cotas como um dos caminhos}

Em quatro casos, a condição da deficiência não representou fator relevante para iniciar a vida profissional. A reserva de vagas serviu para obtenção da primeira oportunidade apenas para Ana, a mais jovem do grupo. Conseguiu seu primeiro emprego com contrato em carteira, como refere, quase dois anos antes da época da entrevista. Marcos e Márcia iniciam por meio de um programa social da empresa, quando a lei de cotas não havia sido regulamentada. Quatro sujeitos simplesmente começaram a trabalhar por indicação de amigos ou familiares.

A política de cotas possibilitou posteriormente novas oportunidades de trabalho. $\mathrm{Na}$ época da pesquisa, todos ocupavam vagas reservadas para pessoas com deficiência em empresas privadas. A exceção foi Alex ocupando cargo comissionado em serviço público na área da deficiência, contratado por sua atuação de destaque na comunidade surda.

Os participantes deixam claro que, a partir do momento em que souberam da lei de cotas e sua fiscalização, começaram a declarar sua deficiência para pleitear colocação ou recolocação no mercado. Até então, para Márcia, a deficiência tinha sido motivo de discriminação observada nas entrevistas de emprego. Com a fiscalização as empresas solicitam esse dado, surgindo serviços de colocação de pessoas com deficiência em instituições e empresas privadas de consultoria.

Para os sujeitos, a lei de cotas contribuiu para enfrentarem o preconceito do mercado, e sua fiscalização deveria ter ocorrido há mais tempo. 
Márcia percebe na lei, a reprodução de outra forma de discriminação. Se a pessoa com deficiência já competia com as pessoas sem deficiência agora com a lei compete com outra pessoa com deficiência, pois o empregador optará pelo candidato com deficiência mais leve. O caráter assistencialista embutido na lei, em sua opinião, reforça a existência de dois mundos: deficiente e não deficiente.

Para o empregador, o aumento dos custos é justificativa para optar pelas deficiências mais facilmente adaptáveis. Existe ainda muita desinformação sobre as deficiências. Segundo João Batista Ribas, que coordena o Programa de Empregabilidade da Pessoa com Deficiência, da empresa SERASA, em São Paulo, os gastos devem ser vistos como investimento para melhorar a qualificação profissional ou adaptar o posto de trabalho. São medidas similares a bolsas de estudo, cursos de aperfeiçoamento oferecidos para outros funcionários. As modificações arquitetônicas beneficiarão não somente pessoas com deficiência mas também aquelas com mobilidade reduzida.

\section{O Ambiente de trabalho}

Não basta contratar pessoas com deficiência para afirmarmos que elas estão incluídas. Faz-se necessário avaliar as condições em que estão trabalhando. A pesquisa levantou dois aspectos da inclusão: a acessibilidade ao ambiente de trabalho e sua integração no ambiente humano

Um documento da OIT - Organização Internacional de Trabalho, traduzido no Brasil em 2004 como Gestão de Questões Relativas a Deficiência no Local de Trabalho, traz uma série de recomendações para reduzir o impacto da deficiência sobre a capacidade de trabalho e interação com o ambiente. Define aspectos, como ajuste ou adaptação do trabalho, incluindo modificação de equipamentos e adequação das tarefas, tendo como objetivo propiciar o acesso ao local de trabalho e facilitar o emprego de pessoas com deficiência.

Márcia nem sempre encontrou ambientes preparados para pessoas cegas. Em seu caso, uma ferramenta fundamental seria o software audível que as empresas onde trabalhou se dispuseram a providenciar. Nessa iniciativa Márcia ressalta a necessidade da pessoa com deficiência orientar sobre suas necessidades especiais. A acessibilidade arquitetônica para pessoas com mobilidade reduzida é mais raro encontrar. Para Alex, somente no atual trabalho, conseguiu uma intérprete de LIBRAS. Outras pessoas que não necessitavam de recursos mais específicos, observam ajustes no mobiliário, equipamentos, rampas para entrada de pessoas 
cadeirantes e adaptações em áreas de uso coletivo. Apesar de se observar iniciativas para tornar o trabalho mais acessível, existe muito desconhecimento dos empregadores sobre a questão das medidas de adaptação. Na visão de custos a falta de acessibilidade tem excluído muitas deficiências abrindo o caminho de novas discriminações. Pessoas com deficiência podem e querem participar da busca de soluções que viabilizem sua inserção nos diversos postos de trabalho.

Quando às relações no trabalho a presença de pessoa com deficiência gera impacto no grupo, apontando a discriminação ainda existente. Nos anúncios de emprego dos jornais, um texto da Constituição alerta os anunciantes:

De acordo com o art. $5^{\circ}$ da $\mathrm{CF} / 88 \mathrm{c} / \mathrm{c}$ 373-A da CLT, não é permitido anúncio de emprego no qual haja referência quanto ao sexo, idade, cor, situação familiar ou qualquer palavra que possa ser interpretada como fator discriminatório, salvo quando a natureza da atividade, pública e notoriamente assim o exigir.

Anúncios de emprego fazem ainda referência à vagas para moças ou rapazes, só falta acrescentar boa aparência. Pelo gênero, aparência, idade e outras exigências, o mundo do trabalho, de forma mais ou menos velada, reproduz uma atitude preconceituosa. Assim pergunta-se: como foi o relacionamento dos sujeitos nos locais de trabalho? Os relatos indicam diversas reações do ambiente: resistência, preconceito, superproteção, deslealdade. Sentiram sua capacidade subestimada, mas também foram elogiadas pelo desempenho, encontrando pessoas dispostas a colaborar e orientar.

O documento da OIT recomenda como estratégia de gestão a comunicação e a sensibilização do local de trabalho, indicando a importância das informações e esclarecimentos de supervisores e funcionários, como elementos facilitadores na inclusão das pessoas com deficiência.

A pesquisa comprovou esse dado: alguns relataram que a sensibilização do ambiente, reduziu as barreiras atitudinais. Os pais de Marcos acrescentam que a supervisão da instituição orientou não somente o seu comportamento mas também o das chefias quanto à forma de lidar e instruir uma pessoa com deficiência intelectual.

No ambiente da empresa Marcos sentiu-se parte do grupo, quando trouxe lembranças como integrante da equipe em um evento de rally promovido pela empresa. Henrique, que possui baixa visão, não esqueceu do elogio do chefe pela qualidade de seu trabalho na 
máquina copiadora. José sentiu-se respeitado, quando incentivado a participar de todas as etapas do treinamento da brigada de incêndio, mesmo com limitações na locomoção.

São marcas da inclusão que ficaram como lição para as duas partes. Depoimentos que revelam o respeito às diferenças, aumentando a crença de que a aprendizagem resultante do convívio com a diversidade pode ser incorporada pelo ambiente de trabalho. Os sujeitos demonstraram sua capacidade de reação e de forma proativa vem assimilando o impacto que pode causar no ambiente de trabalho. Colegas e chefias indicam abertura para o novo, provando que o processo de inclusão é um movimento bilateral.

\subsection{DIREITO DE SER DIFERENTE}

Ouvir as histórias da infância, que falam do convívio com a comunidade, colocounos muito próximos da realidade do cotidiano que cerca as pessoas com deficiência. As lembranças foram surgindo, relatando momentos de conquistas e de perdas, experiências de aceitação e de rejeição.

Quando crianças, as brincadeiras já indicavam o significado de ser diferente. Mesmo assim, Henrique, com sua baixa visão, conseguiu desafiar o primo e pulou de um pé de abacate para o outro. Com foi possível? E como Márcia, cega, andou de patins, de bicicleta, e ainda jogou vídeo game? Os cabelos compridos de Paulo não disfarçavam seu aparelho auditivo, denotando um esforço vão de procurar assemelhar-se ao outro.

Foram muitas histórias revelando uma infância em bairros ou ruas do interior da Bahia, de Minas Gerais ou da capital de São Paulo. Como qualquer outra criança, estavam próximos quando brincavam, ou afastavam-se quando brigados. Sinceridade e honestidade é como Márcia descreve essa relação tão transparente. Alguns se isolaram um pouco, não tiveram tantos amigos. A intervenção do zelador do prédio onde Alex morava foi fundamental, fazendo a diferença durante sua infância. Alex tornou-se um dos melhores jogadores do time de futebol de seu condomínio, depois que o zelador deu uma "chamada na turma".

\section{Entre os iguais e os diferentes}

Os sujeitos em vários momentos falam do preconceito contra aquele que é diferente. 
Quando a escola inclusiva propõe o direito de a criança ficar entre seus pares, é importante ouvir de Alex ou de Márcia quem eles consideram seus pares! Quem são os pares ou os iguais? Como os iguais vêem aquele que tem uma deficiência? $\mathrm{Na}$ área da surdez somos levados a repensar quais são os pares da criança ou do adulto surdo. Alguns especialistas referem a formação da comunidade surda como um ato de resistência à inclusão, defendendo o bilingüismo e a pressão pela oralização do surdo. E os que respeitam a cultura dos surdos, o que estariam defendendo? O direito de ser diferente?

A Língua Brasileira de Sinais foi reconhecida como meio legal de comunicação e expressão pela Lei 10.436 de 24 de abril de 2002. Em seu art.1 parágrafo único refere:

Entende-se como Língua Brasileira de Sinais - Libras a forma de comunicação e expressão, em que o sistema lingüístico de natureza visualmotora, com estrutura gramatical própria, constitui um sistema lingüístico de transmissão de idéias e fatos oriundos de comunidades de pessoas surdas do Brasil.

O Decreto $\mathrm{n}^{\mathrm{o}} 5.626$ de 22 de dezembro de 2005 regulamenta essa lei referindo:

Considera-se pessoa surda aquela que por ter perda auditiva, compreende e interage com o mundo por meio de experiências visuais, manifestando sua cultura principalmente pelo uso da Língua Brasileira de Sinais. (Art.2)

O uso e a difusão da Libras, após o decreto, foi considerado o meio de efetivar os direitos das pessoas surdas. Sua utilização em ambientes educacionais e de saúde garante mais uma medida de promoção da igualdade e equiparação das oportunidades.

Parece que a diversidade começa a ser reconhecida e estamos aprendendo a incorporá-la, sem negar as diferentes identidades. Mas é difícil identificar-se com quem é minoria. A prevalência do padrão da maioria gera estereótipos e alimentam os estigma do corpo, de caráter, ou tribais conforme Goffman (1988). O autor acrescenta:

Em todos esses exemplos de estigma, entretanto, inclusive aqueles que os gregos tinham em mente, encontram-se as mesmas características sociológicas: um indivíduo que poderia ter sido facilmente recebido na relação social cotidiana possui um traço que pode impor-se à atenção e afastar aqueles que ele encontra, destruindo a possibilidade de atenção para outros atributos seus. (p.14)

Ter uma deficiência é sofrer o estigma da invalidez e incapacidade, que, encontrando-se no limiar, torna mais complexo o processo da identificação. Paulo demonstra 
que não é fácil assumir a identidade de ser uma pessoa com deficiência. Para ele, depende do lado em que você se posiciona, reforçando a idéia do estigma que a deficiência gera. Com grau moderado de deficiência auditiva e ótimo nível de oralidade prefere ver sua condição como quem tem um razoável resíduo auditivo, que o aproxima ou o assemelha à maioria. Henrique, em diversos momentos de sua vida, lutou para ter sua deficiência visual reconhecida. Possuindo baixa visão, teve dificuldades de diagnóstico, lembrando o momento de aquisição da telelupa como um dos mais marcantes e comoventes de sua vida.

As pessoas entrevistadas foram aprendendo e ensinando os outros a lidarem com seus limites e potencialidades. Integraram-se nos diversos ambientes, às vezes, hostis, às vezes, acolhedores na vizinhança no colégio ou na faculdade. Aprenderam a conviver em uma sociedade que ainda os exclui e estigmatiza. A criança mostra que consegue se relacionar com a pessoa que está por trás da deficiência. $\mathrm{O}$ adulto parece se relacionar com a deficiência como se ela fosse entidade própria.

Goffman (1988) discorrendo sobre os conceitos de "identidade social real" e "identidade social virtual", demonstra como categorizamos o estranho à nossa frente e lhe imputamos atributos a priori, deixando de nos relacionar com o sujeito real. Quando a pessoa apresenta características diferentes, é mais discriminada, quanto maior for a visibilidade dessa diferença. $\mathrm{O}$ estigma que atinge o aspecto corporal é muito forte entre nós, bastando olhar à nossa volta o culto à forma e à perfeição física. Pessoas com deficiência reagem ao seu desvio frente ao padrão da normalidade da maioria da população, com riscos de prejuízo da sua socialização.

Pelos depoimentos, os sujeitos da pesquisa participaram e participam de grupos heterogêneos não havendo segregação. Os relatos de certo isolamento social durante a infância e início da adolescência foram poucos e superados. Marcos, fora o trabalho, está sempre mais próximo dos pais, não havendo adquirido muita autonomia no aspecto social. Outros se integraram no meio de pessoas com ou sem deficiência. A distinção entre esses dois grupos foi marcada por Alex e Márcia, referindo a duas categorias: ouvintes e surdos, videntes e cegos.

Essa oposição parece fortalecer as diferenças entre os grupos, diferenças que vão além daquelas decorrentes dos sentidos da visão e da audição. Os sujeitos falam de diferenças mais sutis, na forma de brincar ou fazer piadas que não teriam graça, se estivessem no meio de pessoas sem deficiência. 
Em seus relatos indicam ter atingido um nível de integração com os grupos heterogêneos, mantendo a identificação com os iguais. Aceitam ser diferentes e se enriquecem com os desiguais. Márcia refere que às vezes vem sente falta dos amigos cegos. Alex, após a entrevista, iria com seus amigos surdos assistir a uma peça de teatro tendo, como acompanhante uma intérprete de LIBRAS, recurso que ainda não é oferecido em nossos teatros ou outras áreas de lazer.

O desafio da inclusão de pessoas com deficiência não aponta apenas para a necessidade de garantir-lhes espaços na escola e no trabalho. Os sujeitos observam de forma crítica as dificuldades enfrentadas no cotidiano urbano sem adaptações arquitetônicas e condições de transporte e lazer. Reconhecem mudanças importantes na legislação especialmente a lei de cotas, mas percebem que há pouca informação sobre a deficiência na sociedade. Aos poucos começam a se apropriar desses conhecimentos e ter maior participação. José, após sua inserção no programa de cotas da empresa, começou a participar de eventos sobre o tema. Alex refere a forte engajamento em movimentos organizados. Nas últimas eleições, foi o único candidato surdo e mesmo perdendo, ganhou destaque, ingressando em um espaço público direcionado às questões da deficiência, além de participar da direção de uma associação de surdos.

Para esses sujeitos os caminhos da inclusão foram garantidos mas, verificamos que milhares se encontram marginalizados do processo. Os sujeitos desse estudo, em comparação ao restante da população brasileira, são bastante favorecidos. Falar da exclusão de pessoas com deficiência é falar da exclusão social e econômica em que vive a maioria dos brasileiros. E teremos um grande contingente das pessoas com deficiência carregando o duplo fardo: pobreza e deficiência. Caiado (2002) citando Dupas define pobreza como "dificuldade de acesso relativo aos bens e serviços mínimos adequados a uma sobrevivência digna" (p.181).

Segundo a autora é preciso compreender a deficiência na perspectiva histórica e política. O debate é bastante complexo e transformações no cenário da exclusão histórica exigem ações coletivas de defesa de seus direitos.

Não enxergo outro caminho, além da organização social. Pois se a exclusão social das pessoas deficientes não se explica pela deficiência em si (não me refiro a preconceito mas à exclusão social) e sim pelas condições de pobreza, a luta pela inclusão se politiza. A deficiência deixa de ser uma categoria fechada em si mesma e, assim, a pessoa deficiente passa a ser um sujeito histórico, ocupa um lugar social, num tempo marcado. Portanto, as pessoas deficientes que têm negado seu direito de cidadania, precisam lutar por ele. 
Nessa perspectiva, a legislação que anuncia esse direito pode ser um devir importante. (CAIADO, 2003, p.188)

Cada sujeito vem desenvolvendo um papel de agente de mudança, no momento que expõe, reage, aprende e ensina. A organização multiplica a força dessa mudança quando ao lado deles, outras pessoas engrossam a fileira dos "informados" como Goffman (1988) denomina. Todos exercendo seu papel de cidadania podem contribuir para garantir o direito de todas as pessoas a uma vida digna, como declara a nossa Constituição.

Seguem alguns pontos de reflexão deste estudo:

- A escolarização de pessoas com deficiência é o caminho para sua inclusão social. Independente da alternativa educacional, o espaço da escola representa possibilidades de experiência de pertencer, ser aceito e respeitado. Assim quando se fala do preparo da escola inclusiva é importante destacar as relações entre alunos e professores, pois as marcas que deixam podem fazer toda a diferença.

- O apoio da família é fundamental para uma trajetória bem sucedida de inclusão, devendo integrar a discussão das ações educativas na deficiência.

- A deficiência ainda é cercada de preconceitos e estigmas, sendo o caminho da informação uma forma de combater a discriminação. Os elementos dificultadores da inclusão apresentam em comum a face do preconceito, enquanto valores de respeito à diversidade marcam os caminhos facilitadores da inclusão.

- A aceitação das diferenças é um exercício de aprendizagem mútua e suas lições estão no contexto da escola inclusiva, da empresa inclusiva, provocando uma postura mais crítica nas pessoas. O convívio com pessoas com deficiência gera oportunidade de aprendizagem. 


\section{CONSIDERAÇÕES FINAIS}

O tema inclusão e deficiência vem despertando um interesse crescente na sociedade, denotando mudanças no olhar para as pessoas que representam a diversidade. A escuta de suas expectativas e vivências ofereceu-me a oportunidade de aprender indicando aspectos facilitadores e dificultadores nos caminhos da inclusão. Sim, porque os caminhos são diversos porém eles se cruzam na discriminação e preconceito mas se encontram também no respeito e solidariedade.

As narrativas de vida revelaram sentimentos de inclusão e de exclusão dos sujeitos, dentro de uma história individual que não é linear. Ora se deparam com a dificuldade do meio social para lidar com a diferença, ora com sua capacidade de aprender com ela. Ao falarem das conquistas denunciam as carências. Provocam um olhar crítico sobre a exclusão da população de um ensino de qualidade, de uma oportunidade de trabalho.

A discussão da escola inclusiva passa pela avaliação do compromisso dos educadores com seu ofício de educar. Exige apoio e vontade política para mudanças. Na escola pública ou particular os sujeitos enfrentaram muita desinformação e despreparo de professores, ambientes pouco acolhedores, mas também experenciaram apoio solidário e interesse genuíno de alguns professores, abrindo possibilidades de mudanças. Ampliar as oportunidades de inclusão escolar das pessoas com deficiência não significa apenas matrícula garantida mas sobretudo elevar a qualidade da educação, o que envolve a atenção a todos os alunos. Independentemente de suas diferenças biológicas, sociais, culturais, ideológicas, todos têm direito a apropriação do conhecimento e formação da cidadania.

O caminho da inclusão escolar levará à inclusão no trabalho. Há necessidade de garantir a formação educacional avaliar os resultados de uma política de cotas para emprego e adequá-la às mudanças no mundo do trabalho. A cultura organizacional vem se modificando para um contexto de inclusão da diversidade, combatendo as formas de discriminação no trabalho. O modelo de gestão de responsabilidade social e ambiental envolve temas como ética e cidadania, associa desenvolvimento sustentável e inclusão social seguindo a Norma 16001 criada pela Associação Brasileira de Normas Técnicas - ABNT. Nesse cenário de transformações das organizações e relações de trabalho, a contratação de pessoas com deficiência mais que uma obrigação legal passa a representar compromisso com a responsabilidade social e valorização da diversidade. 
Foram muitos depoimentos de histórias de vida, que trouxeram valiosos registros de experiência de convívio de pessoas com deficiência na vida escolar e no trabalho, em épocas e lugares variados. Enfrentando as barreiras do preconceito e discriminação da sociedade, demonstraram que a luta pela inclusão é vivida no plano pessoal do cotidiano, mas também reflete a condição histórica de um grupo social: a escola que viveram, a cidade em que moram, o lugar em que trabalham. Reconstruíram o cenário da infância, da família, através das narrativas de suas lembranças. Provocaram algumas identificações, fazendo-nos repensar como colegas, educadores, empregadores, nosso compromisso enquanto cidadãos e profissionais da área da deficiência.

Ao ouvir todas essas histórias, não pude deixar de reviver também a minha historia de vida profissional, o meu trabalho em instituições especializadas, período em que procurava respostas, caminhos para o desenvolvimento e integração das crianças e dos adolescentes, orientações para atender a ansiedade e expectativa de suas famílias quanto ao seu futuro.

Posso seguramente afirmar que há 30 anos sequer imaginava que estaria hoje auxiliando as empresas a contratar e incluir pessoas com deficiência. Lembro de uma fala de um pai no final dos anos 90, de que não demoraria muito para vermos anúncios em jornais oferecendo vagas para as pessoas com deficiência. Não era profecia, era alguém que fazia uma leitura histórica, alguém que no movimento organizado das famílias, discutia e participava ativamente do debate acerca das mudanças necessárias na sociedade, para garantir os direitos de seus filhos com deficiência.

Quando vejo a escola discutindo o modelo da inclusão, observo pelas ruas as rampas de acesso nos estabelecimentos comerciais, vagas reservadas em estacionamentos, o reconhecimento da pessoa com deficiência como um usuário ou consumidor, a contratação de intérprete de LIBRAS nas faculdades, surdos passeando nos shoppings, ônibus adaptados começando a circular pela cidade, decretos regulamentando leis que eliminam as barreiras físicas, palestras de sensibilização em empresas que começam a avaliar a qualidade de gestão das pessoas com deficiência contratadas, tenho provas de que mudanças positivas aconteceram. É um processo longo de luta e aprendizado, extremamente gratificante para quem fez parte dessa história. 


\section{REFERÊNCIAS}

ADORNO, T. W. Educação e emancipação. São Paulo: Paz e Terra, 1995.

AMARAL, L. A. Conhecendo a deficiência (em companhia de Hércules). São Paulo: Robe, 1995.

ASSOCIAÇÃO DOS PAIS E AMIGOS DOS EXCEPCIONAIS DE SÃO PAULO APAESP. Disponível em: <www.apaesp.org.br>.

BARDIN, L. Análise de Conteúdos. Lisboa: Edições 70, 1977.

BRASIL. Lei de Diretrizes e Bases da Educação Nacional. Lei n ${ }^{\circ}$ 9394/96, de 20 de dezembro de 1996.

. Declaração de Salamanca. 2ªed. Brasília: CORDE, 1997.

Decreto $n^{\circ} 3298$ de 20 de dezembro de 1999. Regulamentação da Lei $n^{\circ} 7853$, de 24 de outubro de 1989.

. Decreto $n^{o}$ 5296/ 04. Regulamentação da Lei n ${ }^{0} 10.048 / 00$ e Lei no 10.098 / 02.

Decreto $n^{\circ} 5626$ de 22 de dezembro de 2005. Regulamentação da Lei n ${ }^{\circ} 10.436 / 02$.

Ministério da Educação. Resolução CNE/CEB $n^{\circ}$ 2, de 11 de setembro de 2001. Brasília: MEC/ SEESP, 2001.

Ministério Público Federal Considerações sobre os Direitos das Pessoas Portadoras de Deficiência. Procuradoria Federal dos Direitos do Cidadão, 2002.

Ministério Público Federal $O$ acesso de Pessoas com deficência às classes e escolas comuns da rede regular de ensino. Procuradoria Federal dos Direitos do Cidadão, 2003.

BUENO, José Geraldo Silveira. Educação Especial Brasileira: integração/ segregação do aluno diferente. São Paulo: EDUC, 1993. 
CAIADO, Kátia Regina Moreno. Lembranças da Escola: histórias de vida de pessoas deficientes visuais. Tese (Doutorado em Educação), Faculdade de Educação, Universidade de São Paulo, São Paulo, 2002.

CAMINHOS DA INCLUSÃO. Revista. Osasco, SP: Espaço da Cidadania, 2005.

CARREIRA, D. "A integração da pessoa deficiente no mercado de trabalho". In: MANTOAN, M. T. E. et al. A integração de pessoas com deficiência. São Paulo: Memnon, 1997.

CLEMENTE, C. A. Trabalho e inclusão social de portadores de deficiência. Osasco: Gráfica e editora Peres, 2003.

; CELESTINI, E. C. Trabalhando com a Diferença: responsabilidade social e inclusão de portadores de deficiência. Edição especial. Brasília: MTE/ GM Assessoria Internacional, 2004.

CROCHIK, J. Leon. Preconceito: individuo e cultura. São Paulo: Robe, 1995.

D’ANTINO, M. Heloísa Fama. A máscara e o rosto da instituição especializada: marcas que o passado abriga e o presente esconde. São Paulo: Menon, 1998.

DA ROS, S. Zanatta. "Política Nacional de Educação Especial - Considerações". In: Cadernos CEDES. n.23. São Paulo: Cortez, 1989. p.23-28.

DIVISÃO DE EDUCAÇÃO E REABILITAÇÃO DOS DISTÚRBIOS DA EDUCAÇÃO DERDIC/ PUC-SP. Disponível em: <www.pucsp.br/derdic>.

DUSCHATZKY, Sílvia; SKLIAR, Carlos. "O nome dos outros. Narrando a alteridade na cultura e na educação". In: LARROSA, Jorge; SKLIAR, Carlos (Orgs.). Habitantes de Babel: políticas e poéticas das diferenças. Belo Horizonte: Autêntica, 2001. p.119-138.

EDLER CARVALHO, Rosita. Temas em educação especial. Rio de Janeiro: WVA Ed.,1998. FONSECA, Vitor da. Educação Especial. Porto Alegre: Artes Médicas, 1987. 
FRIGOTTO, Gaudêncio. “Os delírios da razão: crise do capital e metamorfose conceitual no campo educacional”. In: GENTILI, P. (Org.). Pedagogia da Exclusão: o neoliberalismo e a crise da escola pública. Petrópolis, RJ: Vozes, 1995. p.77-90.

FUNDAÇÃO GETÚlIO VARGAS - FGV. Centro de Políticas Sociais. Disponível em: <www.fgv.br/cps/deficência_br/PDF>.

GOFFMAN, Erving. Estigma:notas sobre a manipulação da identidade deteriorada. $4^{\mathrm{a}} \mathrm{ed}$. Rio de Janeiro: Zahar, 1982.

GUHUR, M. de Lourdes Peixoto. “A Representação da Deficiência mental numa perspectiva histórica". Revista Brasileira de Educação Especial. Vol.I, n.2, 1994. p.75-83.

INSTITUTO DE CEGOS PADRE CHICO. Disponível em: <www.padrechico.org.br〉.

JAIME, L. R.; CARMO, J. C. A Inserção da Pessoa com Deficiência no Mundo do Trabalho: o resgate de um direito de cidadania. São Paulo: Ed. dos autores, 2005.

JORNAL DA TARDE. São Paulo, 21/11/07.

LAMARA. Associação Brasileira de Assistência ao Deficiente Visual. Disponível em: <www.laramara.org.br>.

LEME, M. I. da Silva. "A construção do si mesmo cultural”. In: SOUZA, M. T. C. (Org.). São Paulo: Casa do Psicólogo, 2004. p.103-121.

LOPES, G. G. V. A Inserção do portador de deficiência no mercado de trabalho: a efetividade das leis brasileiras. São Paulo: LTr, 2005.

LÜDKE, M; ANDRÉ, M. E. D. A. Pesquisa em Educação: Abordagens qualitativas. São Paulo: EPU, 1986.

MANTOAN, M. Teresa Égler. A integração de pessoas com deficiência: contribuições para uma reflexão sobre o tema. São Paulo: Memnon: Editora SENAC, 1997.

MAZZOTTA, M. J. da S. Educação Especial no Brasil: histórias e políticas públicas. São Paulo: Cortez, 1996.

MÉSZÁROS, István. O Século XXI socialismo ou barbárie. São Paulo: Boitempo, 2003. 
MINAYO, M. C. S. (Org.). Pesquisa Social - Teoria, método e criatividade. Petrópolis, RJ: Vozes, 1994.

O Desafio do Conhecimento - Pesquisa Qualitativa em Saúde. 9aed. São Paulo: Hucitec, 2006.

MORAES, C. S. V. "O que há de novo na educação profissional no Brasil”. Trabalho $e$ Educação. Revista do NETE - FaE/UFMG, nº8, jan./jun. 2001. p.13-45.

MORAES, L.; BELIZÁRIO, V. Diversidade humana nas empresas: uma questão de competitividade ou de responsabilidade? Rio de Janeiro: Papel Virtual Editora, 2005.

NERI, Marcelo. et al. Retratos da Deficiência no Brasil. Rio de Janeiro: FGV/ IBRE, CPS, 2003.

OLIVEIRA, M. K. de. "Sobre diferenças individuais e diferenças culturais: o lugar da abordagem sócio-cultural”. In: AQUINO, J. G. (Org.). Erro e fracasso na escola: alternativas teóricas e práticas. São Paulo: Summus, 1997. p.45-61.

ORGANIZAÇÃO INTERNACIONAL DO TRABALHO - OIT. Gestão das questões relativas à deficiência no local de trabalho: repertório das recomendações práticas da OIT.

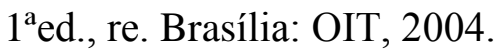

PASTORE, J. Oportunidades de trabalho para portadores de deficiência. São Paulo: LTr, 2001.

PROFISSIONALIZAÇÃO da Pessoa Deficiente - Bolsas de Trabalho. Seminário. CENESP Centro Nacional de Educação Especial e APAE-SP. São Paulo, novembro de 1986.

REGO, T. C. Vygotsky: uma perspectiva histórico-cultural da educação. Petrópolis, RJ: Vozes, 1995.

Memórias da escola: cultura escolar e constituição de singularidades. Petrópolis, RJ: Vozes, 2003.

SASSAKI, R. K. Inclusão. Construindo uma sociedade para todos. Rio de Janeiro: WVA, 1997. 
Inclusão. Construindo uma sociedade para todos. $5^{\mathrm{a}} \mathrm{ed}$. Rio de Janeiro: WVA, 2003.

SENAC. Departamento Nacional. Deficiência e Competência - Programa de Inclusão de Pessoas Portadoras de Deficiência nas ações educacionais do SENAC. Rio de Janeiro: Ed. SENAC Nacional, 2002.

SEVERINO, A. J. Metodologia do Trabalho Científico. 22aed. São Paulo: Cortez, 2002.

STAINBACK, S.; STAINBACK, W. Inclusão: um guia para educadores. Porto Alegre: Artmed, 1999.

STROOBANTS, M. “A visibilidade das competências”. In: ROPÉ, F.; TANGUY, L. (Orgs.). Saberes e Competências. O uso de tais noções na escola e na empresa. Campinas: Papirus, 1997.

VEER, R. V. D.; VALSINER, J. Vygotsky: uma síntese. São Paulo: Unimarco Editora e Edições Loyola, 1996. p.207-265.

VEIGA-NETO, A. "Incluir para excluir". In: LARROSA, Jorge; SKLIAR, Carlos (Orgs.). Habitantes de Babel: políticas e poéticas das diferenças. Belo Horizonte: Autêntica, 2001. p.105-118.

VYGOTSKY, L. S. A Formação Social da Mente. 6ªed. São Paulo: Martins Fontes, 1998. 


\section{ANEXOS}

\section{ANEXO 1 - FICHA DE IDENTIFICAÇÃO DO SUJEITO DA PESQUISA}

Nome:

D.N. Idade Naturalidade

Endereço

Cidade/Estado tel

Escolaridade / Profissão do pai

Escolaridade / Profissão da mãe

Escolas freqüentadas (nome e categoria)

(1) pública (2) particular (R) regular (E) especializada

Ensino fundamental

Ensino Médio

Ensino Técnico (nome do curso e escola)

Ensino Superior (nome do curso e escola)

Tipo de deficiência

Data da entrevista 1

Horário: início horas / término horas 


\section{ANEXO 2 - ROTEIRO DA ENTREVISTA (PONTOS DE INVESTIGAÇÃO)}

1. conquista do primeiro trabalho

2. convivência dentro do ambiente de trabalho

3. medidas de acessibilidade

4. lei de cotas

5. lembranças da vida escolar

6. lembranças da vida familiar

7. cotidiano na infância

8. experiências que representaram sentimentos de inclusão

9. experiências que representaram sentimentos de exclusão

10. opinião sobre o movimento de inclusão de pessoas com deficiência na sociedade 